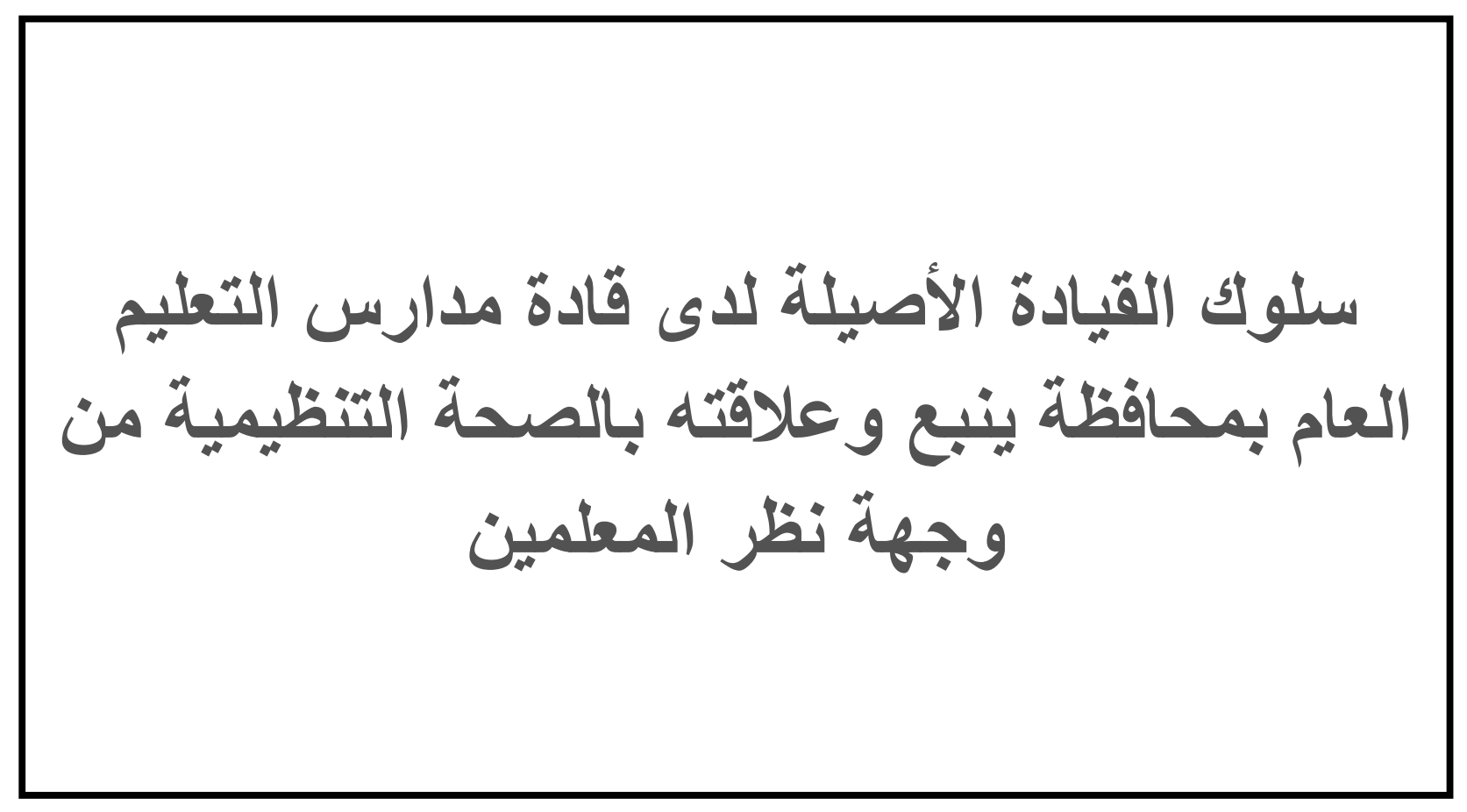

$$
\begin{aligned}
& \text { إعداد الباحث } \\
& \text { أحمد بن منصور بن ظاهر الجهني } \\
& \text { إشر افـ } \\
& \text { د. أحمد بن محمد الزايدي }
\end{aligned}
$$

$$
\text { شعبان ع ع ا هـ مايو } 9 \text { 1 • ب م }
$$




\section{سلوك القيادة الأصيلة لاى قادة مدارس التعليم العام بمحافظة ينبع وعلاقته بالصحة التنظيمية من وجهة نظر المعلمين}

الباحث: أحمد بن منصور بن ظاهر الجهني

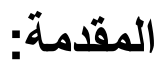

تو اجه المنظمات في القرن الو احد و العشرين تحديات غير مسبوقة ، إذ أن حجم التغيرات التئ التي أحدثتها

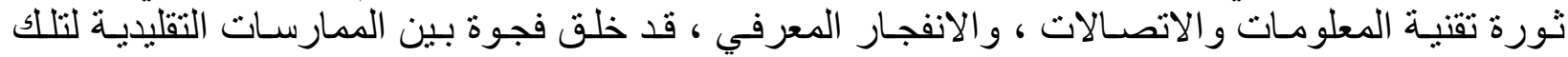

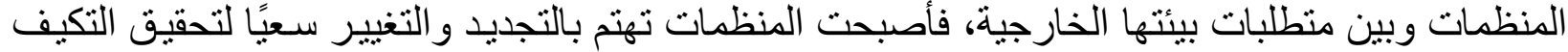

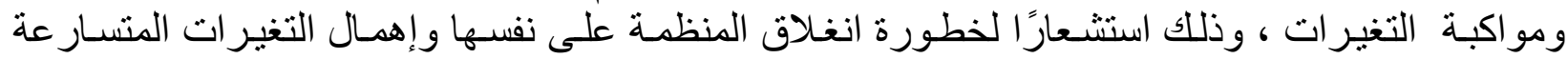

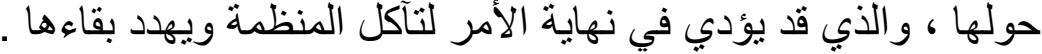

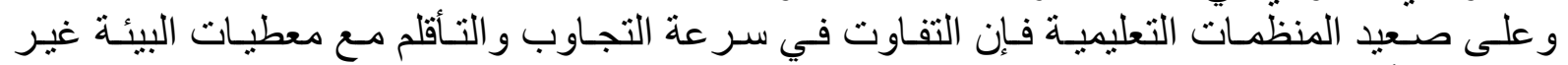

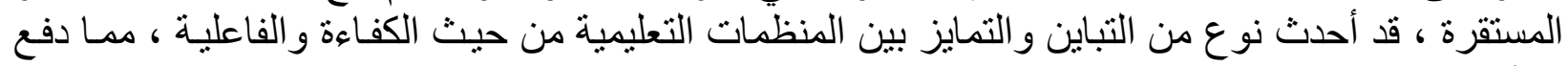

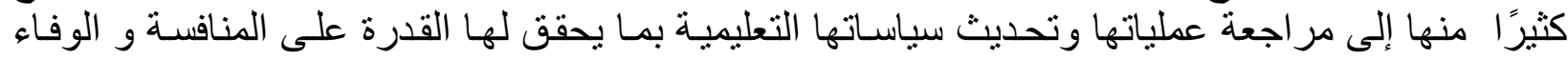
بمنطلبات مجتمعها وتطلعاتها

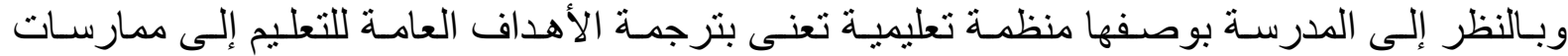

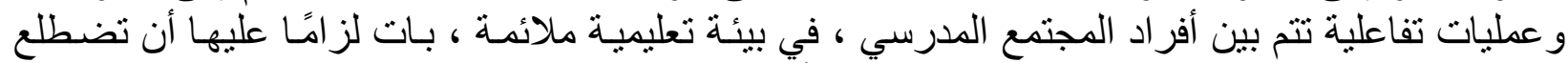

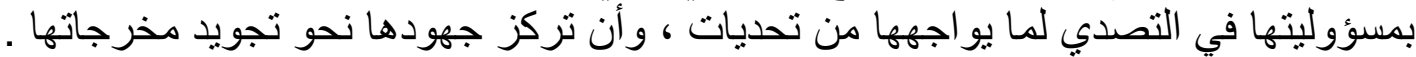

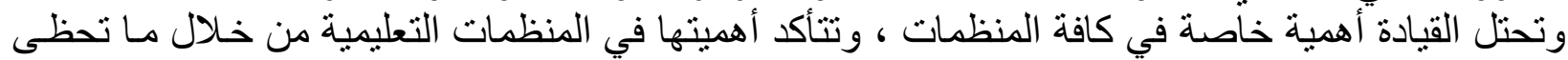

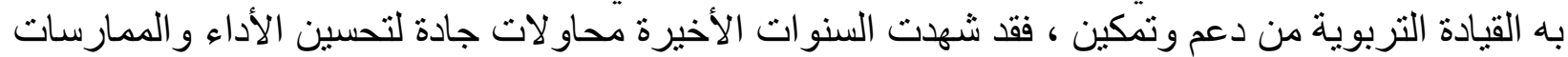

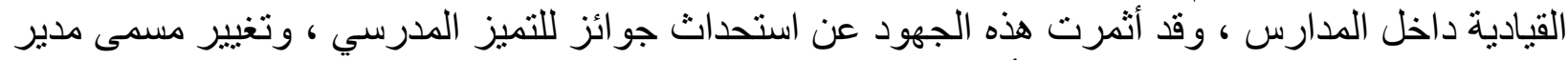

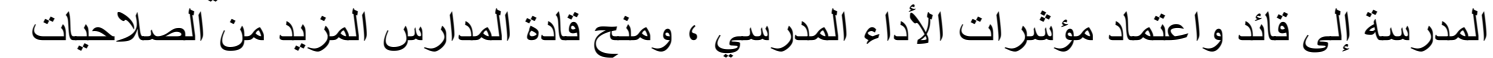

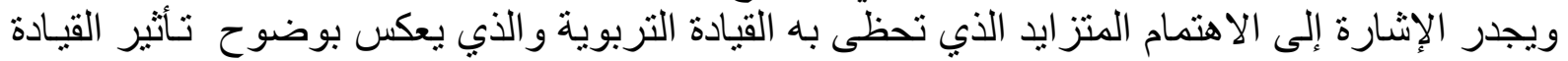

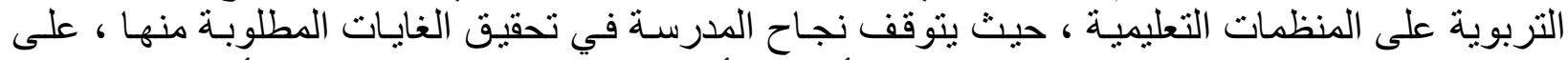

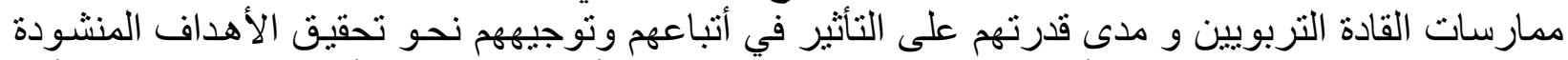

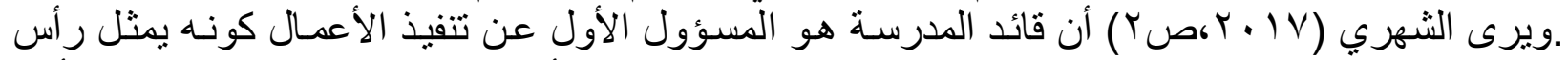

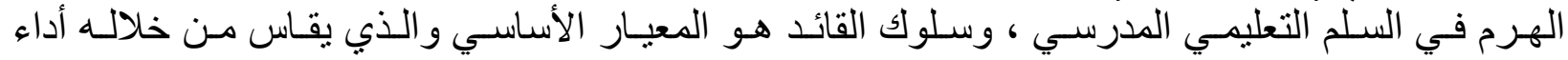

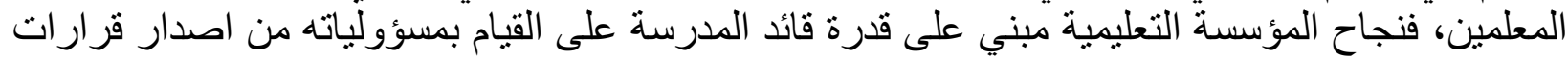

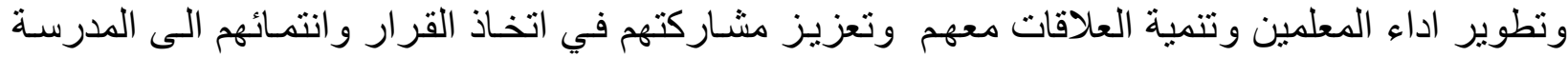

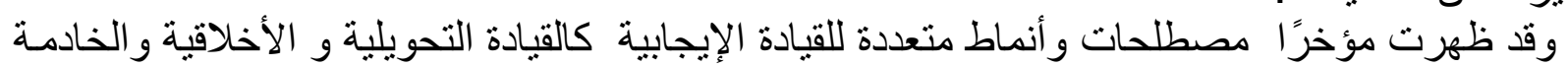

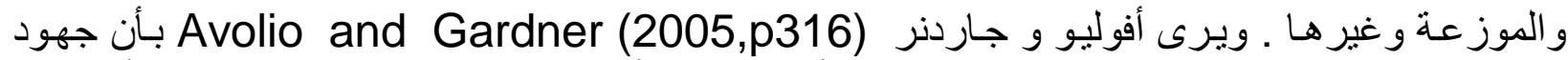

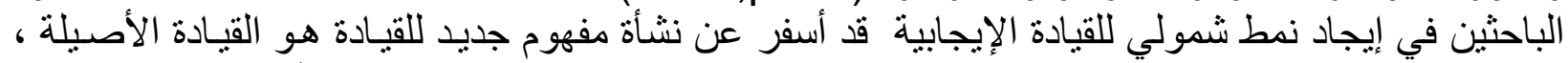

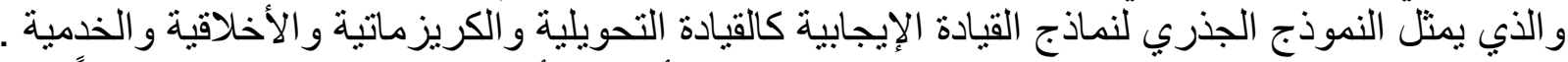

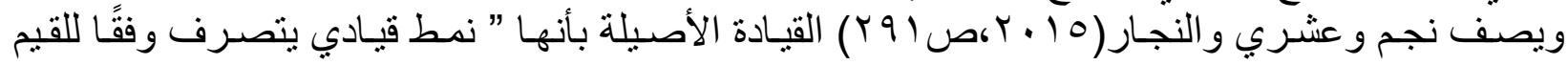

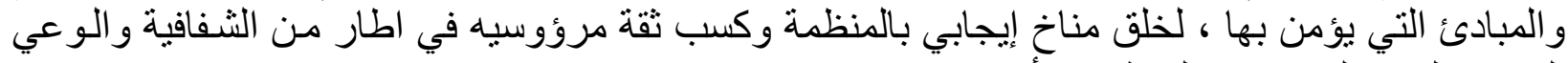

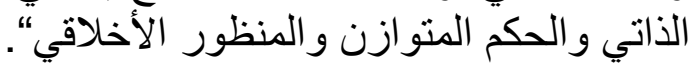

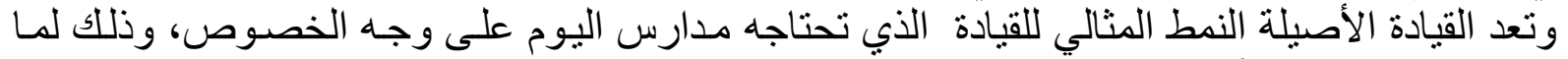

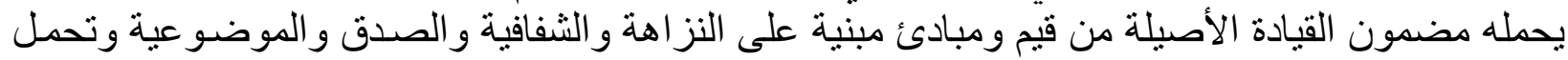

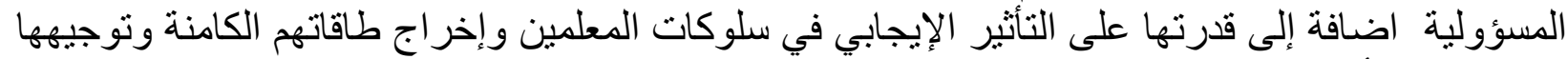
نحو تحقيق الأهداف المنشودة (كيتس دي فر ايزئ، Kets de Vries, 2006,p.376). 
وتتجلى قيمة القيادة الأصيلة في العلاقة القوية التي يبنيها القائد مع مرؤوسيه ، و التي تسهم في خلق ثقافة

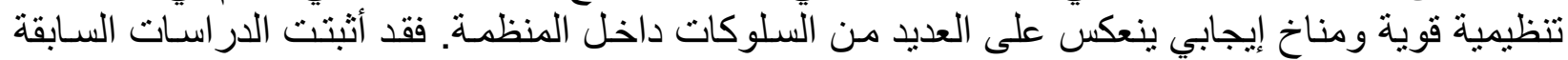

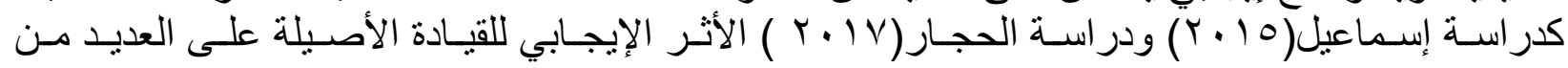

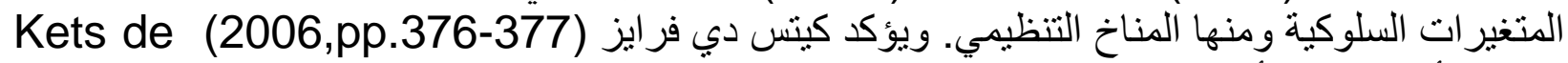

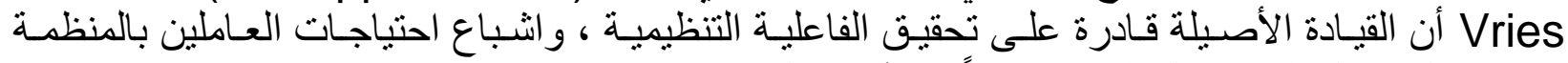

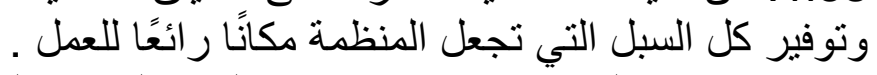

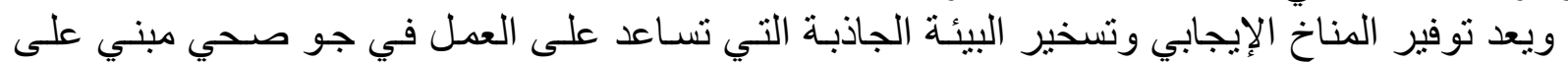

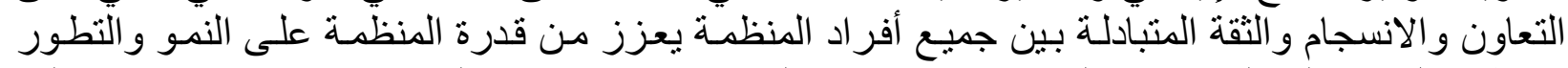

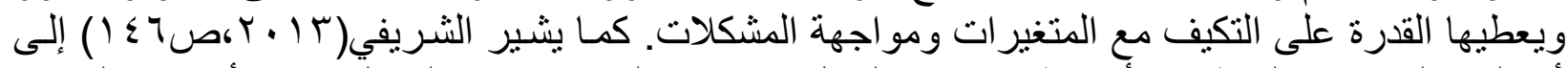

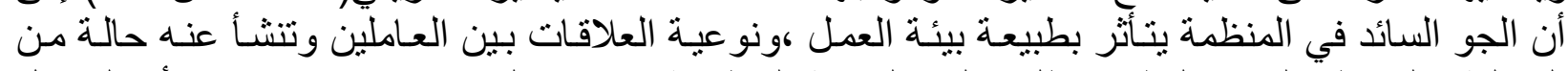

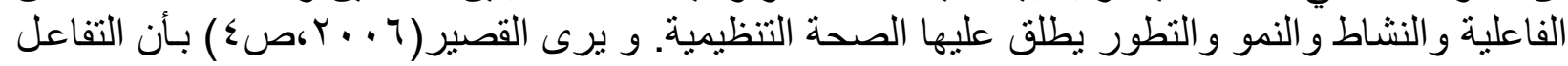

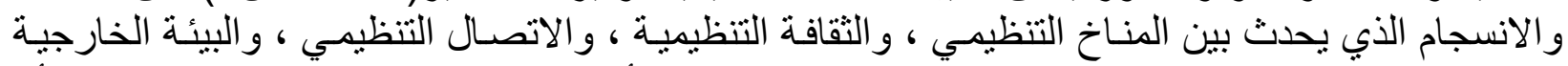

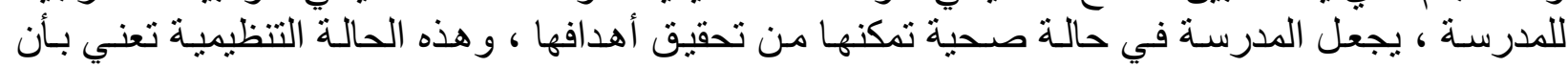
المدرسة تتمتع بمستوى عالٍ من الصحسة المدرسة التظيمية. ويعرف مايلز Miles(1969,pp17-22 الصحة التنظيمية على أنها مقدرة المنظمة على العمل العمل بكفاءة

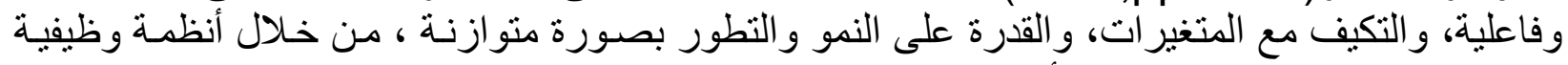

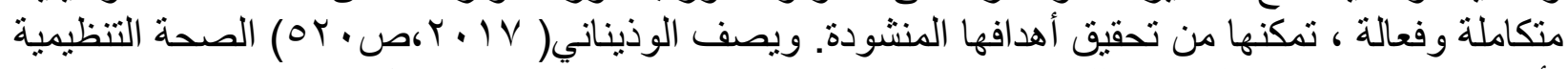

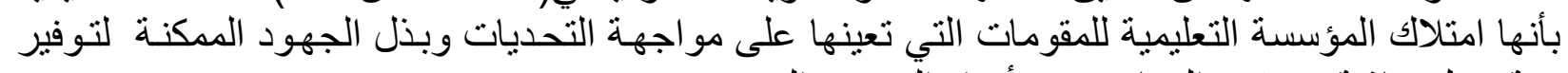

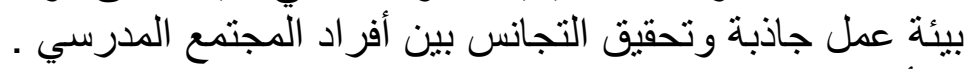

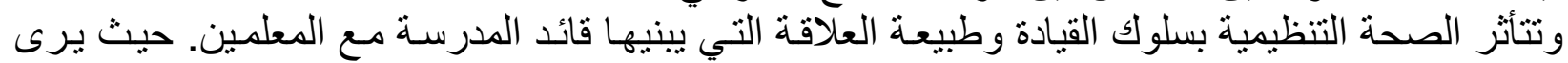

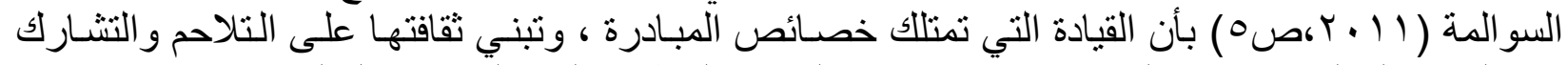

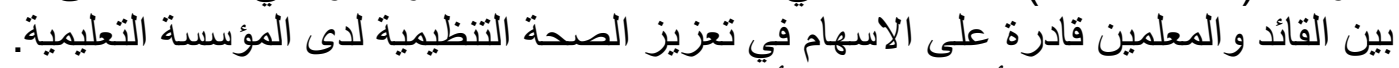

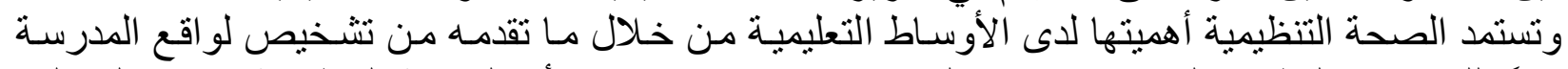

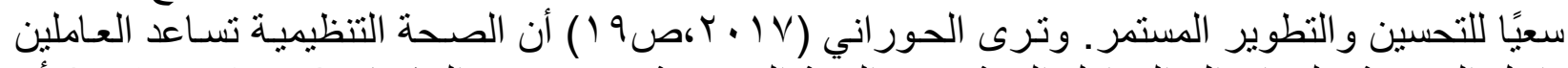

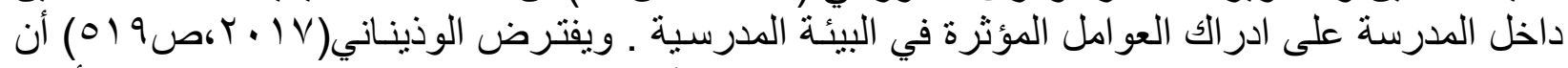

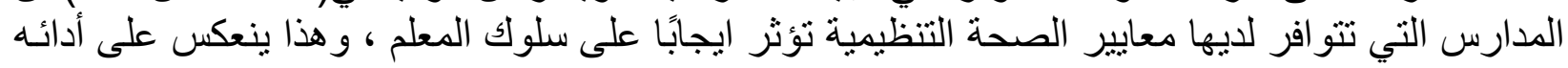
ونتائج طلابهة.

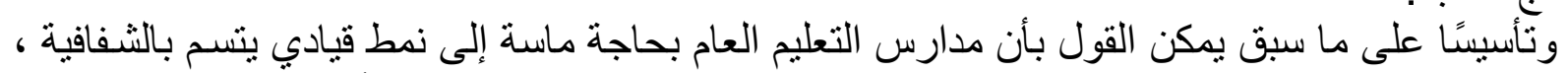

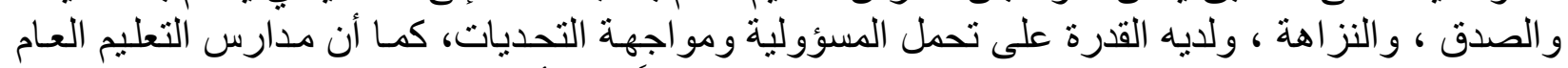

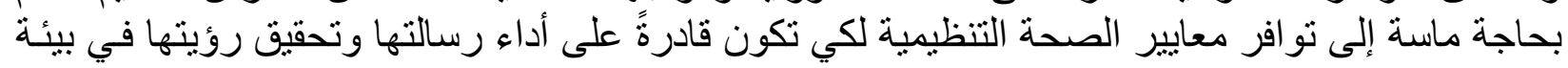

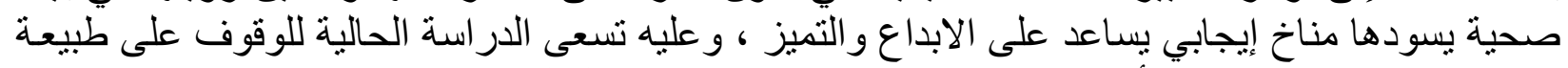

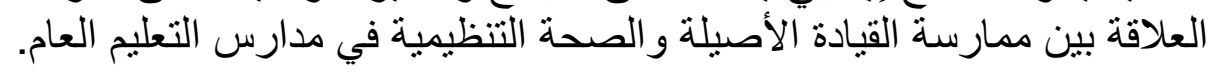

\section{مشكلة البحث: - 20}

إن الاصلاح التعليمي الذي تقوده وزارة التعليم لتطوير مدارس التعليم العام والذي أسفر عن إطلاق عدد

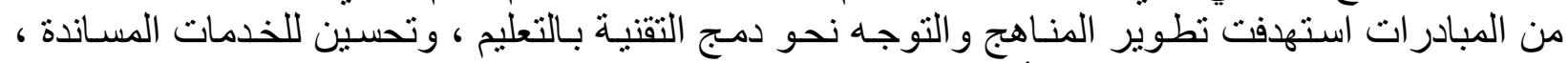

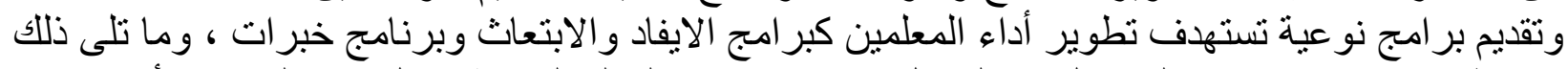

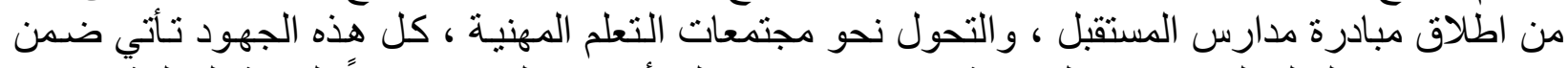

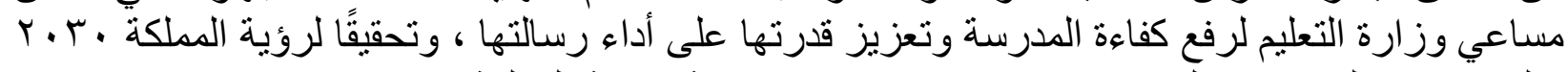

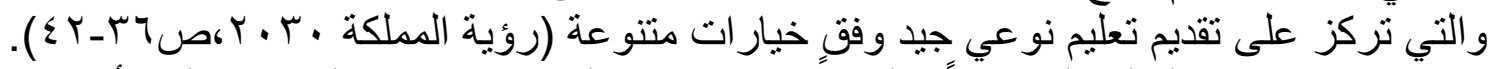

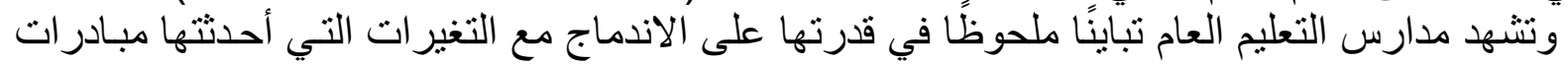

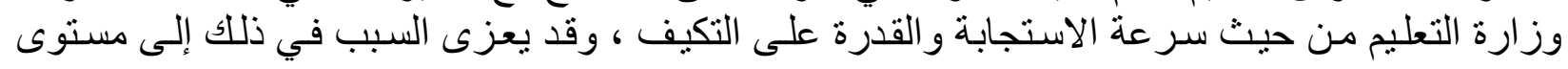




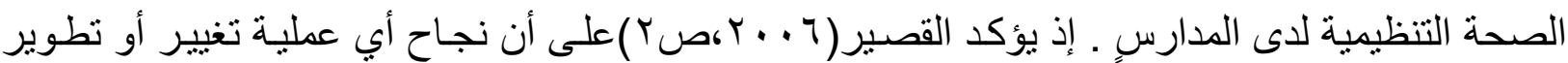

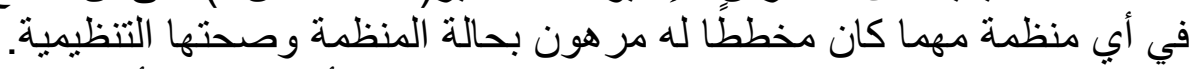

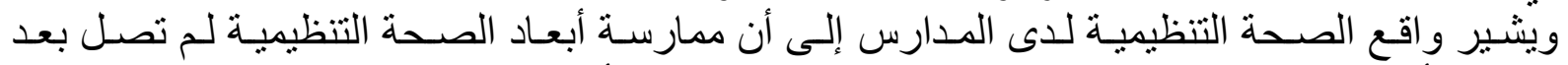

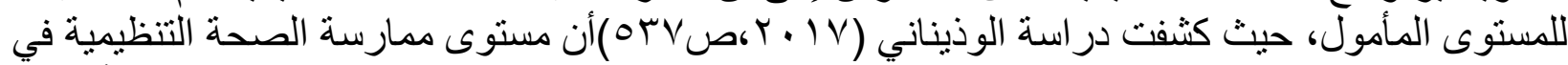
المدارس جاء بدرجة متوسطة ، ممـا بؤثر بشكلٍ عـام على نشـاط المدرسـة وفاعليتها في تحقيـق الأهداف المنشودة.

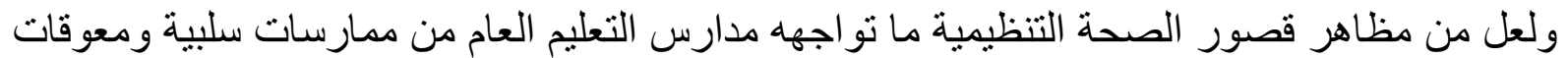

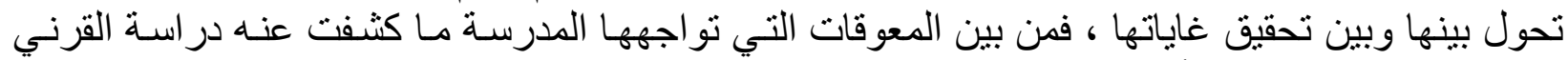

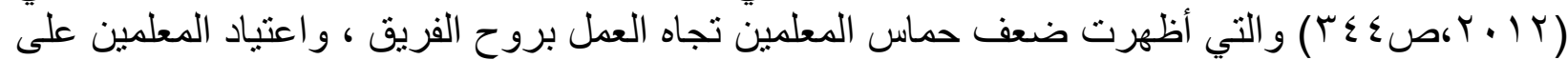

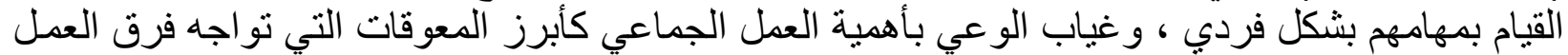

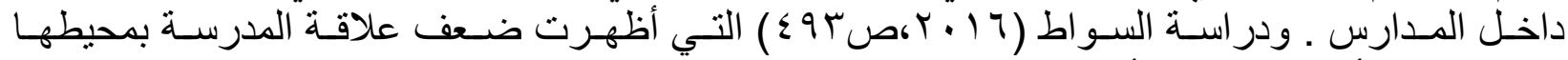

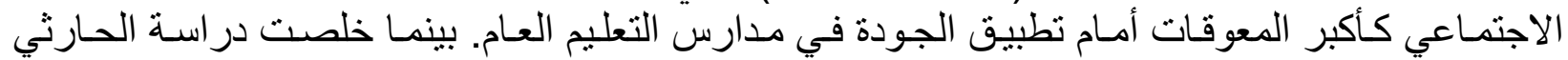

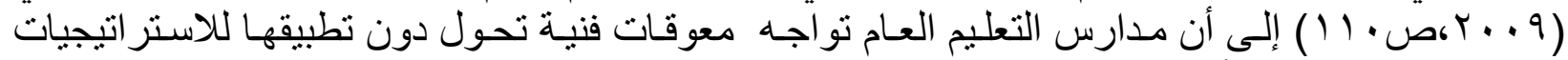

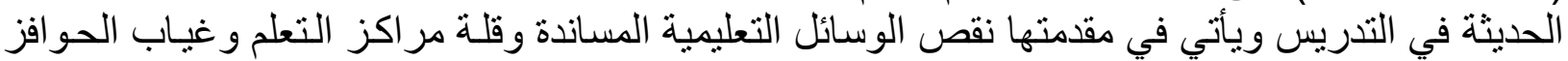
للمعلمين.

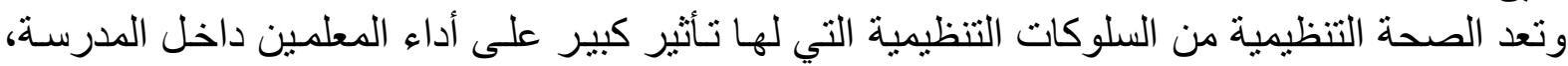

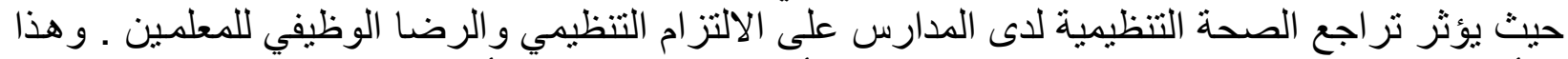

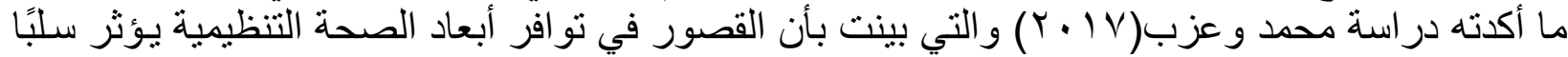

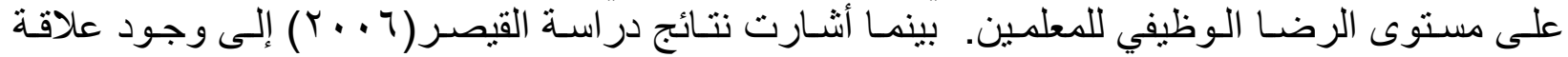

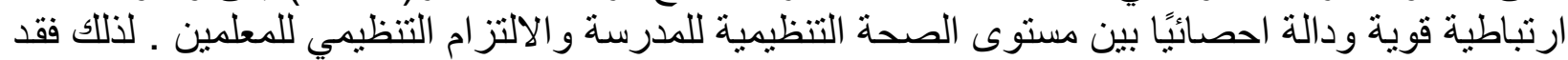

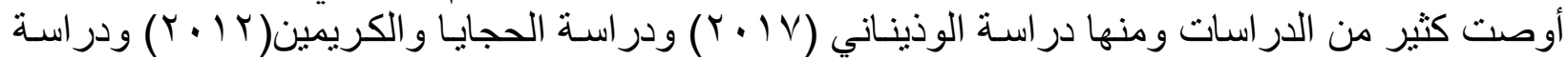

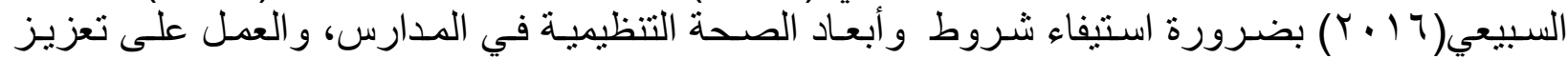

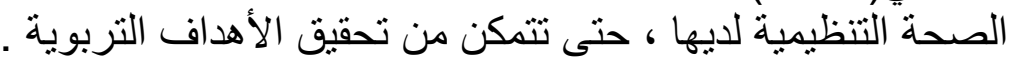

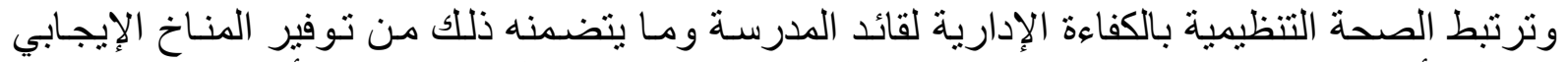

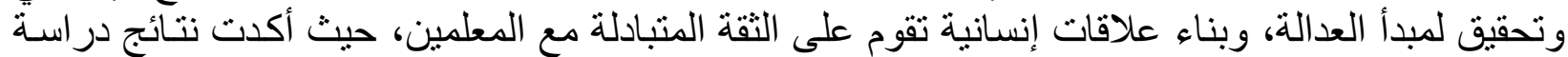

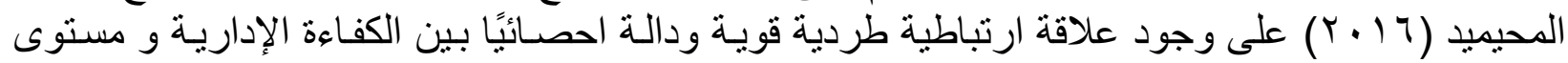
الصحة التنظيمية .

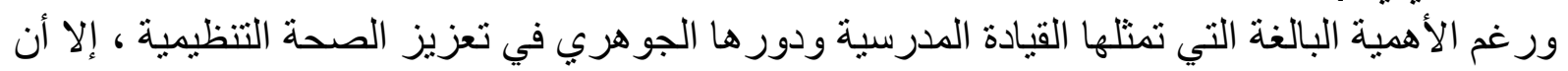

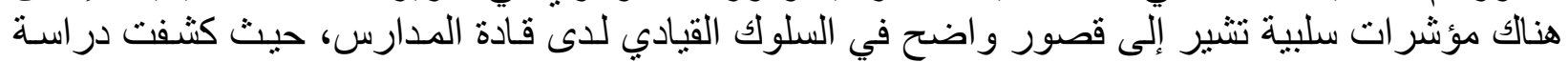

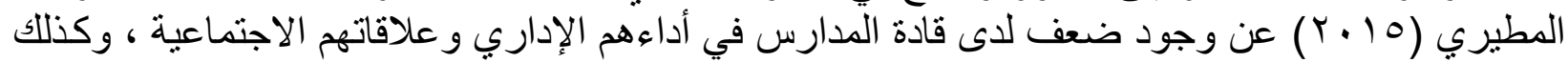

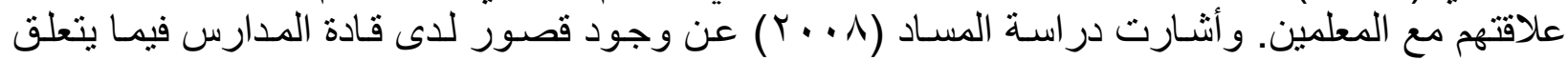

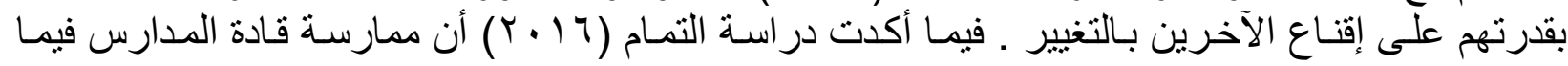

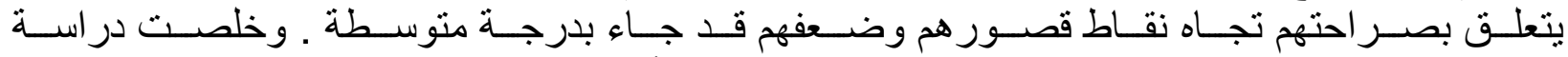

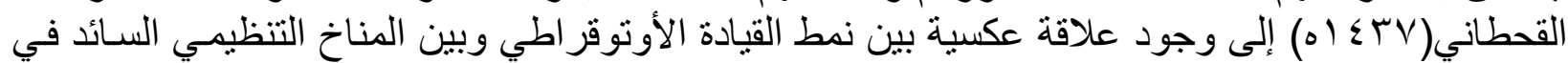

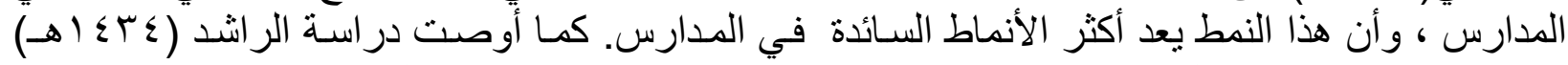

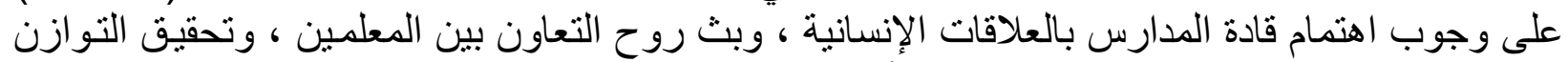

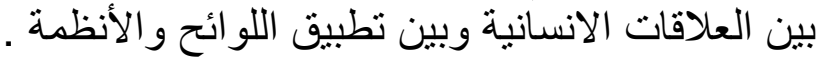

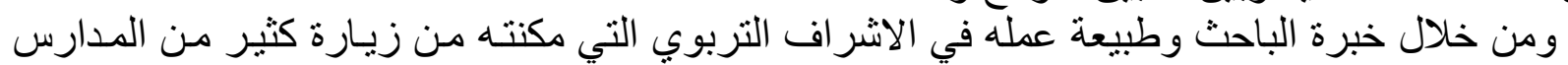

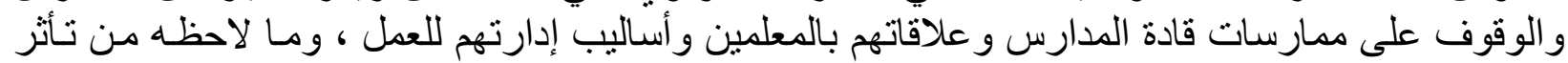

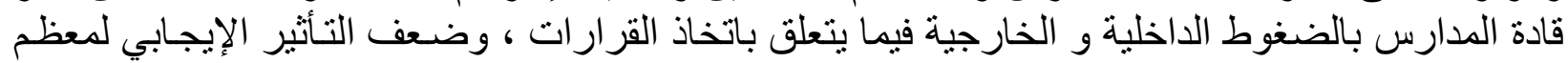

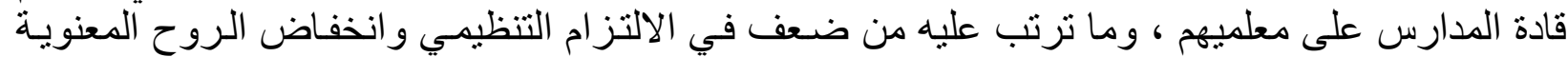

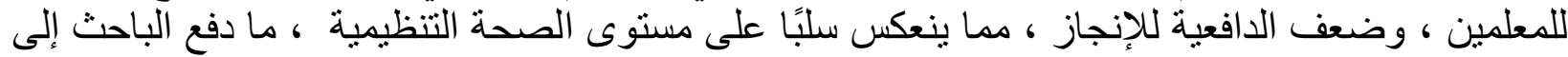

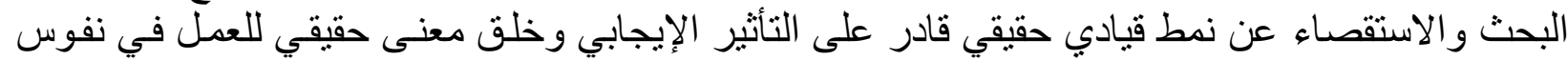

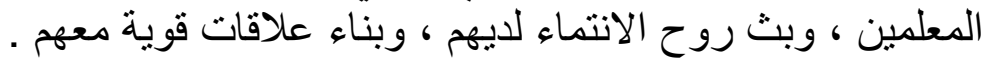


ونظرًا لما تأكد لاى العديد من الدراسات من آثار إيجابية لسلوك القيادة الأصيلة في ميادين العمل بشكل

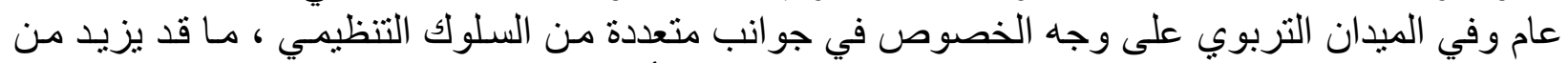

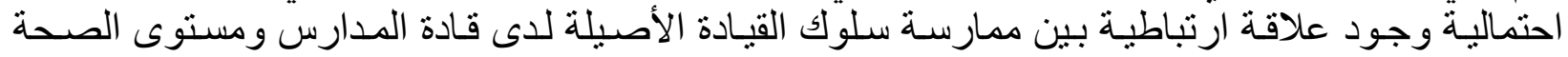

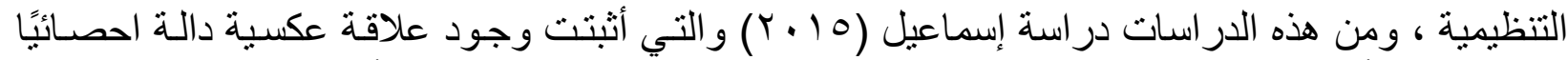

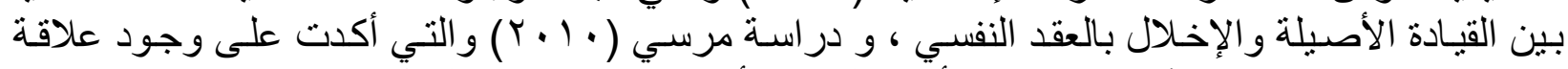

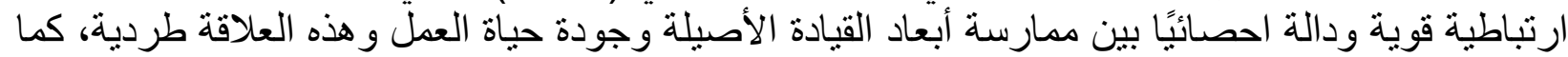

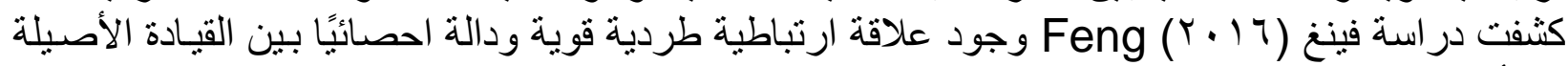

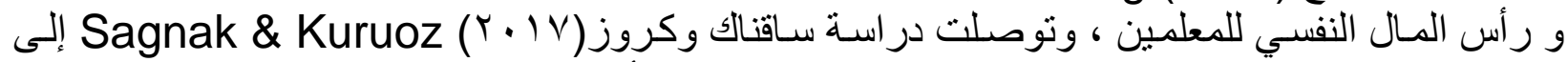

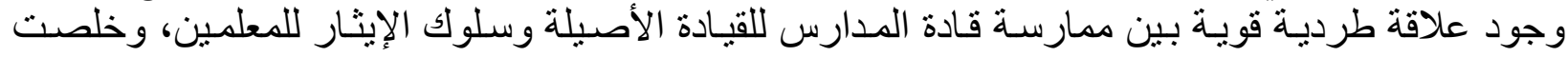

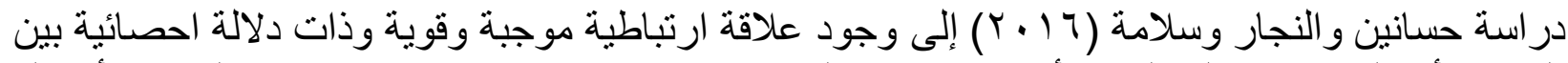

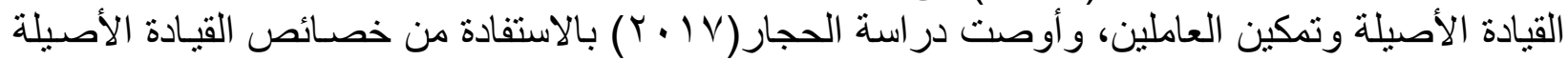

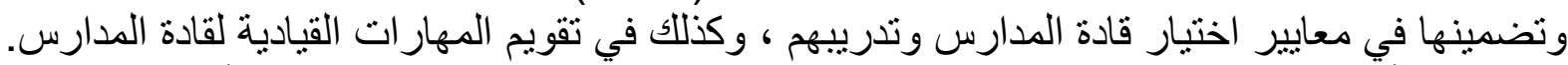

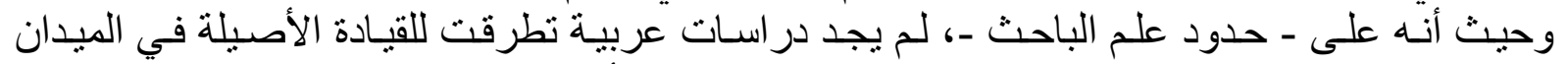

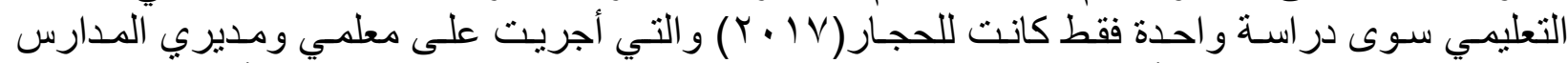

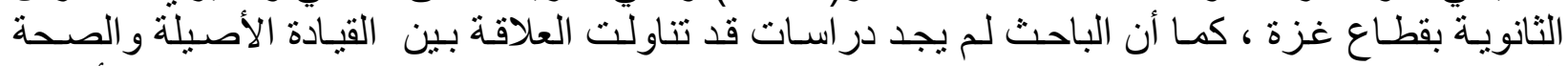
التنظيمية ، لذى فقد جاءت رغبة فأنة الباحث في الكثف عن طبيعة العلاقة بين ممارسة سلوك القيادة الأصيلة

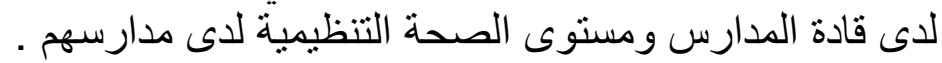

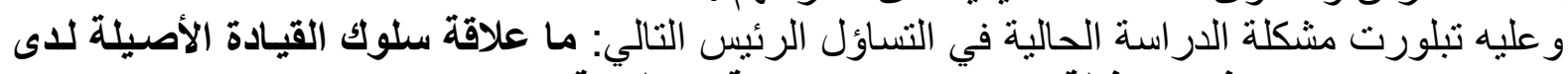

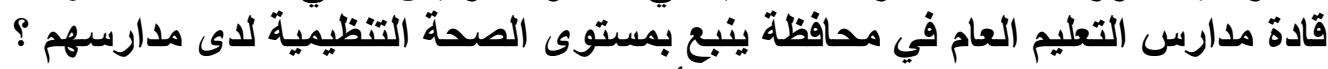

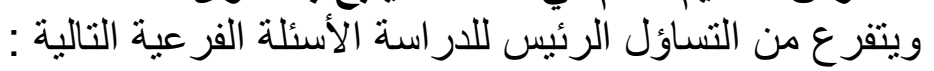

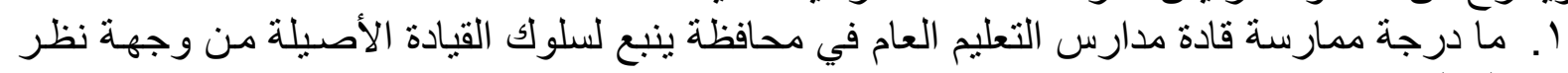

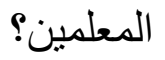

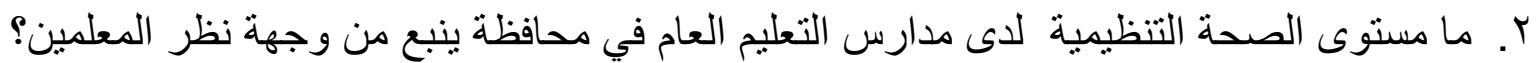

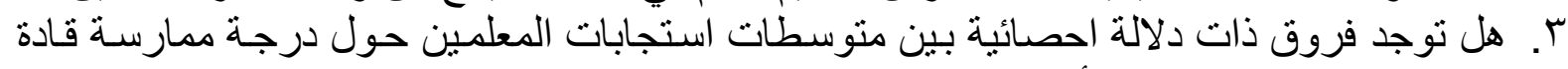

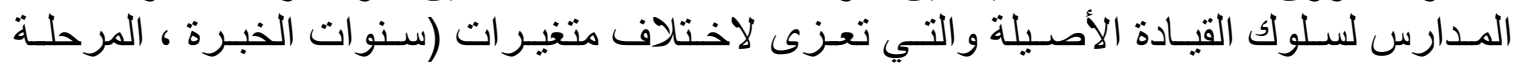
التعليمبة)؛

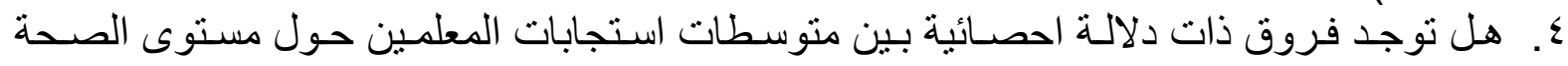

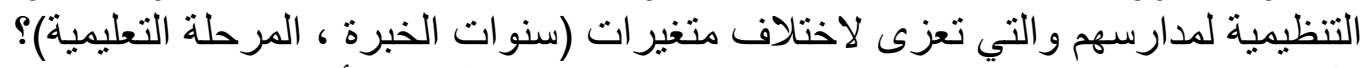

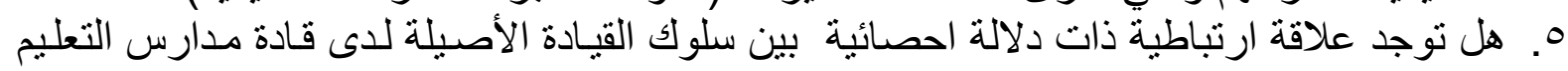

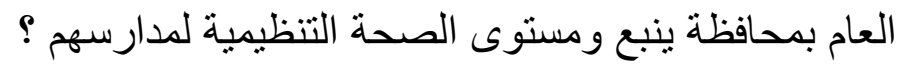

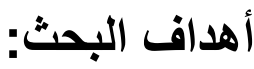

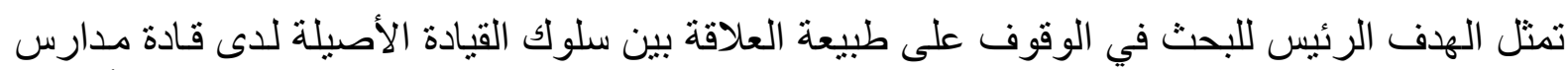

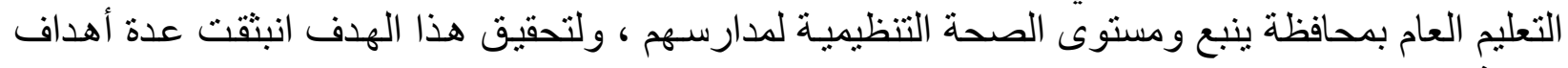

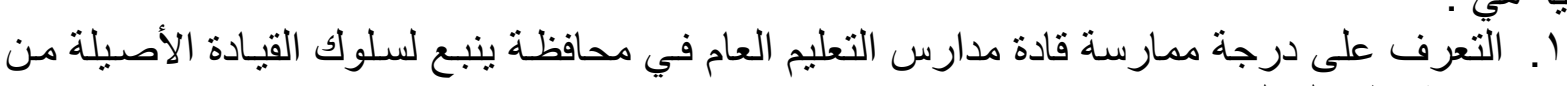
فر عية هي : (لأنيم وجهة نظر المعلمين. r. التعرف على مستوى الصحة التظيمية لدى مدارس التعليم العـام في محافظلة ينبع من وجهة نظر المعلمين. ب. الكثف عن الفروق ذات الدلالة الإحصائية بين متوسطات استجابات المعلمين حول درجـة ممارسـة

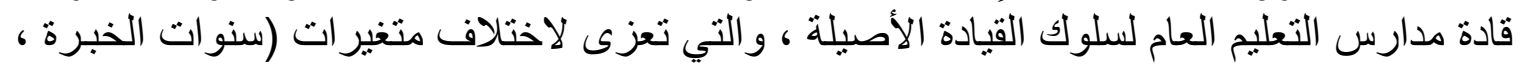
المرحلة التعليمية). 
ع. الكثف عن الفروق ذات الدلالة الإحصائية بين متوسطات استجابات المعمين حول مستوى الصحة

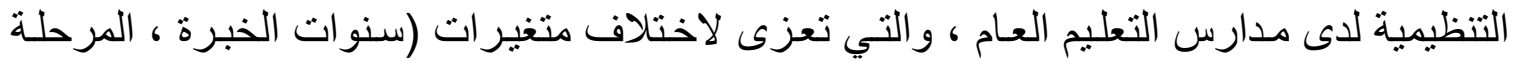
•. الكثف عن طبيعة العلاقة الارتباطية بين ممارسة قادة مدارس التعليم العام في محافظة ينبع لسلوك

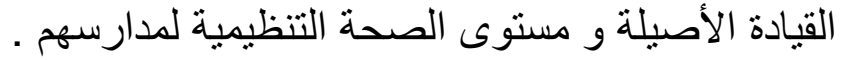

\section{أهمية البحث:}

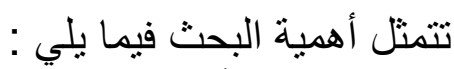

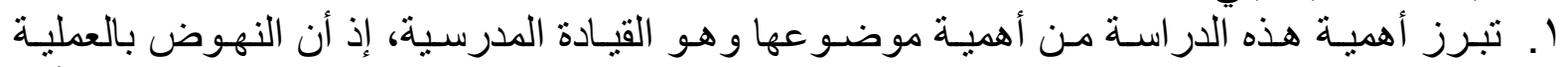

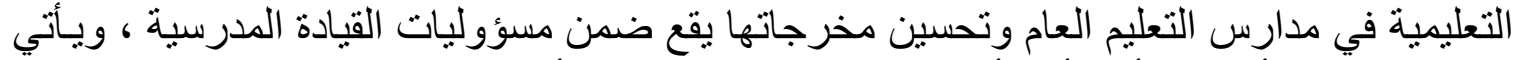

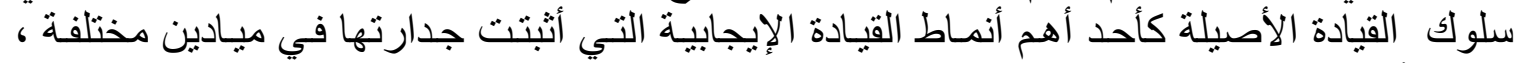

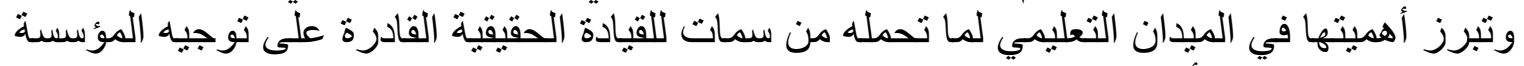

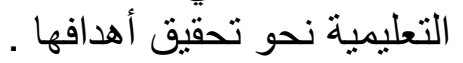

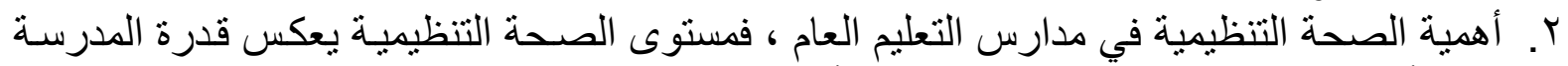

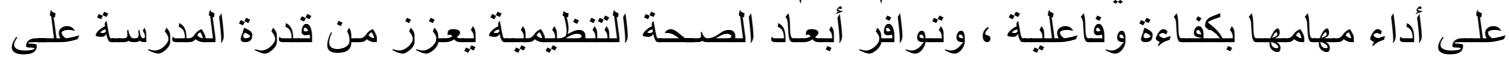
مو اجهة التحديات ، ويسهم في خلق ثقافة قوية تقوم على التعاون والاحتر ام المتبـادل بين المعلمين

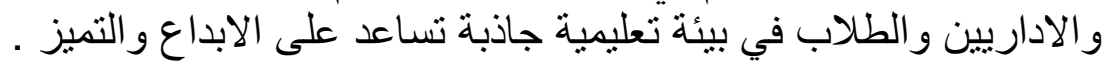

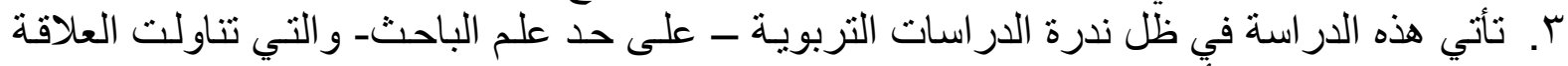

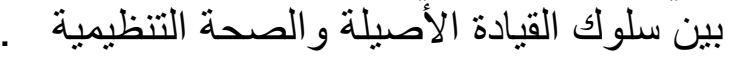

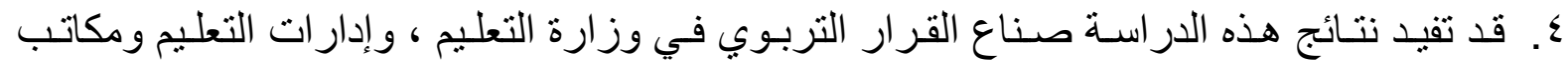

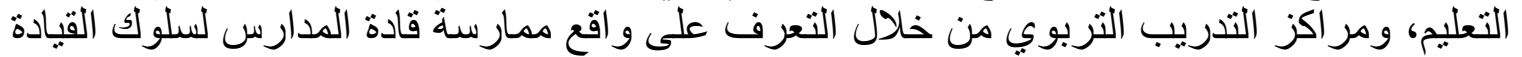

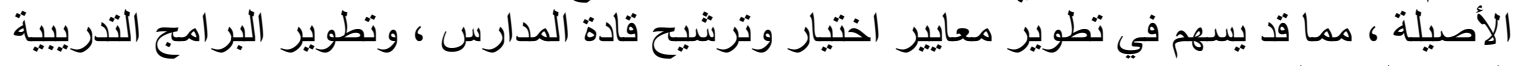

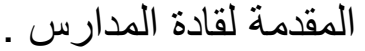

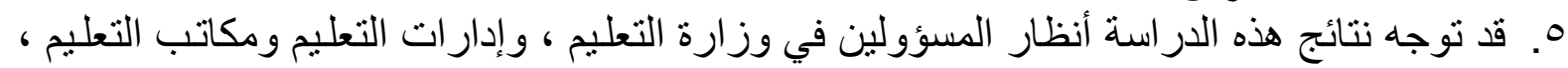

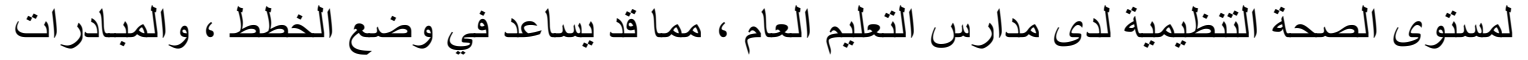

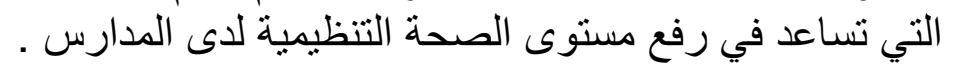

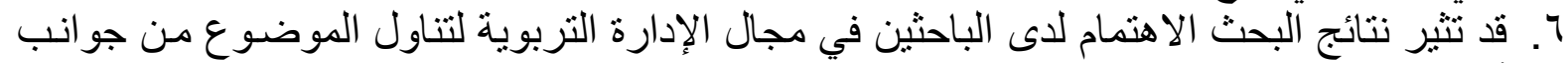

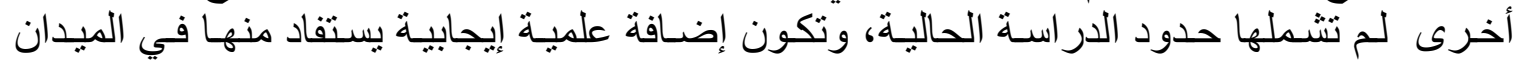
التعليمي . حدود البحث :

اقتصر البحث على الحدود التالية:

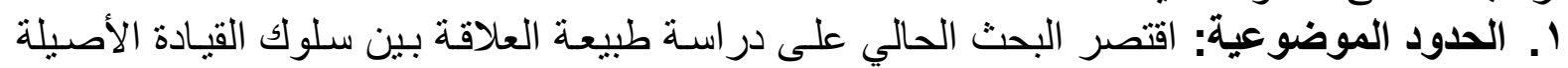

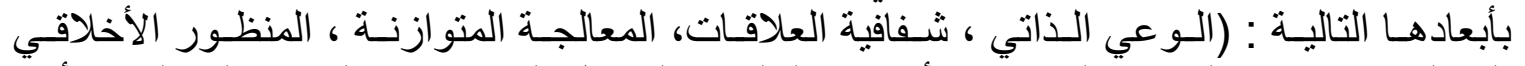

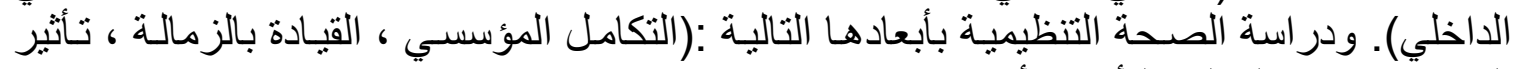
الموارد، انتماء المعلم، التأكيد الأكاديمي).

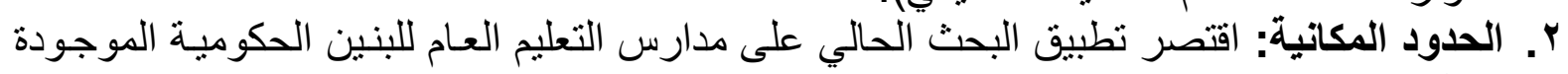

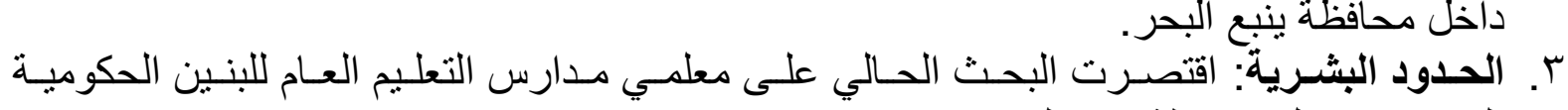

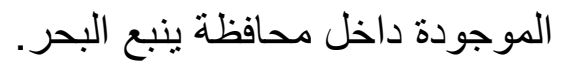

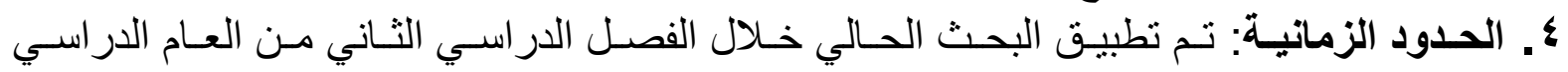

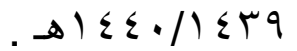




\section{تمثلت المصطلحات الأساسية للبحث ، فيما يلي:}

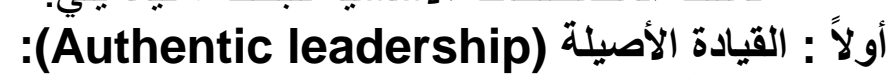

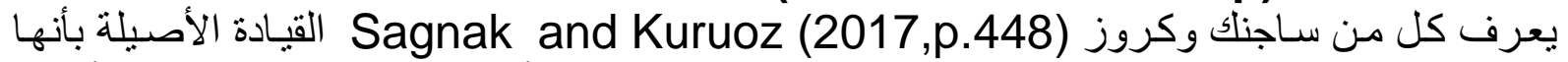

سلوك القائد الذي ينبع من إدر اكه لقيمه وقيم الآخرين ووجهات التهات نظر هم الأخلاقية ، ويظهر فيه القائد الأصيل بانيل

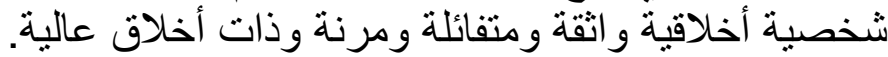

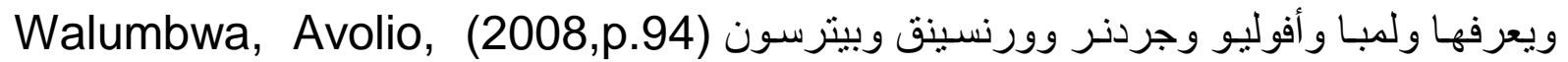
Gardner, Wernsing, \& Peterson

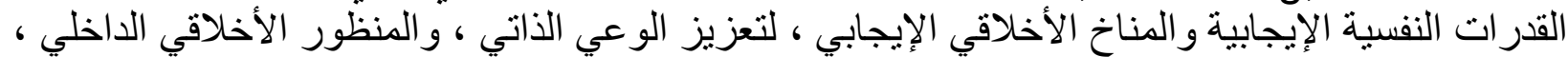

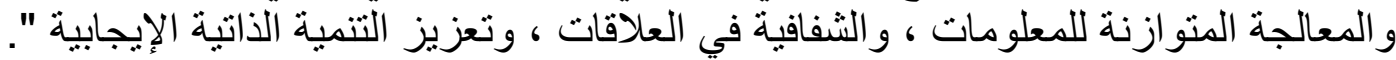

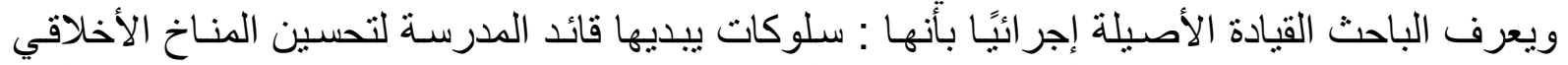

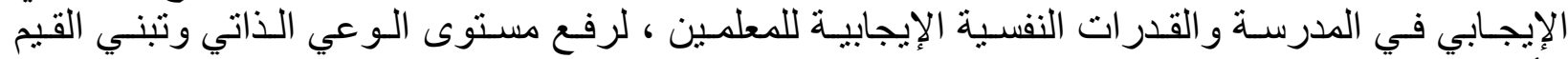

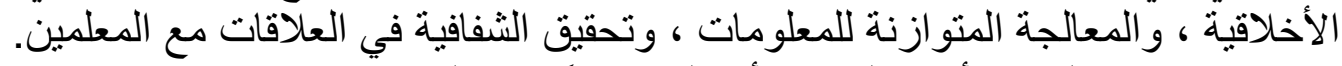

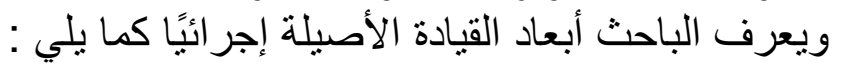

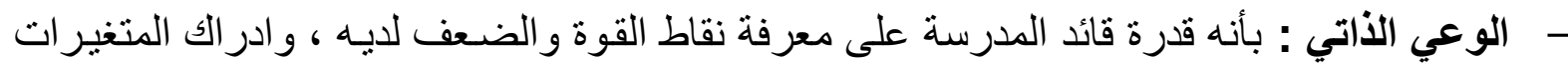
المحيطة و أثر ها على بيئة المدرسة.

- - المعالجة المتوازنة : ويقصد به قدرة قائد المدرسة على تحليل المعلومات و المو اقف بموضو عية

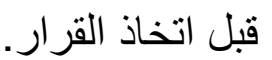
- - المنظور الأخلاقي الداخلي : ويعني أن سلوك قائد المدرسة وممارسـاته تحكمها القيم والمعتقدات

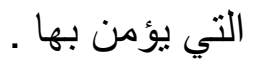

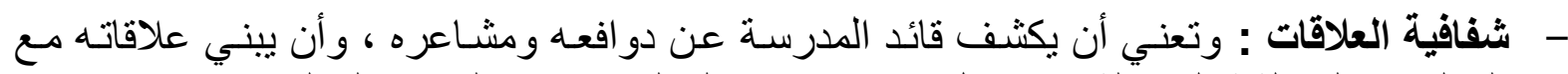

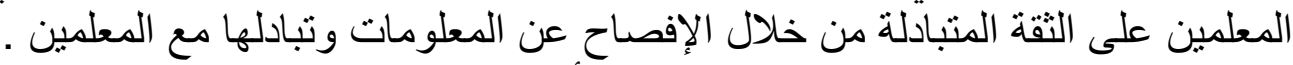

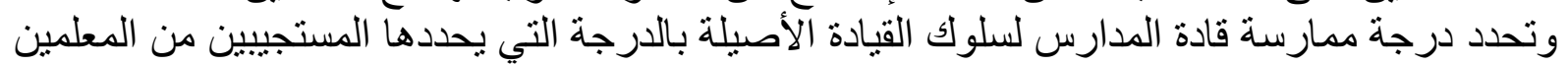

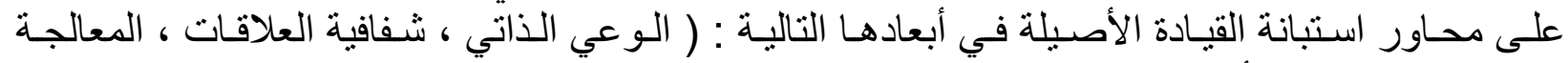
المتوازنة، المنظور الأخلاقي الداخلي).

ثانياً: الصحة التظيمية (Organizational Health): عرفها وولف Wolff (2003,p7) بأنها ما تقوم به المنظمة من اجر اءات تهدف من خلالها إلى تحسين

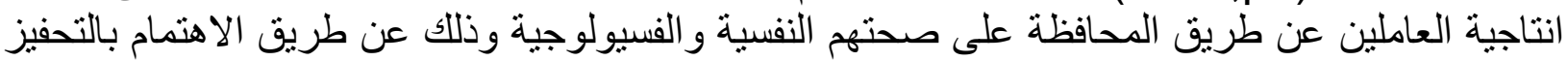

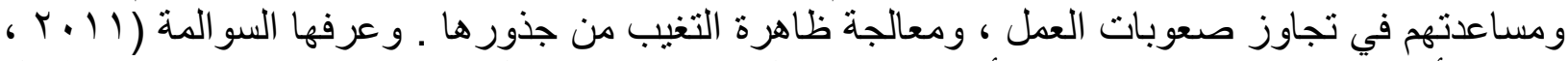
صج9 ) بأنها قدرة الددرسة على تحقيق أهدافها من خلال نظام وظيفي فعال يضمن لها التكيف و والنمو و العمل بكفاءة.

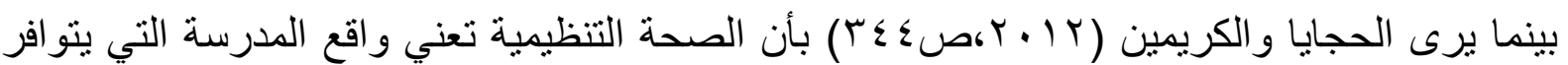

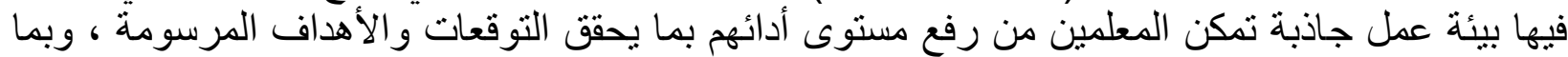

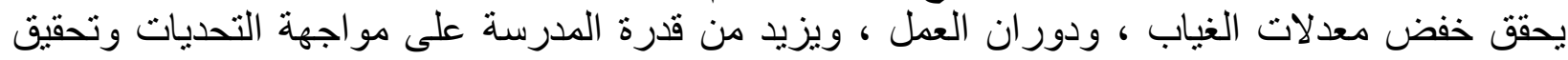

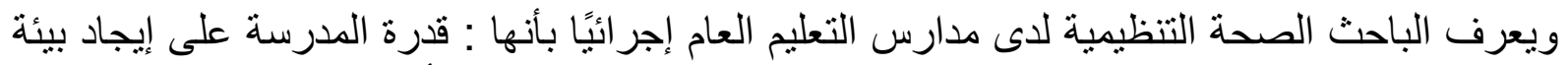

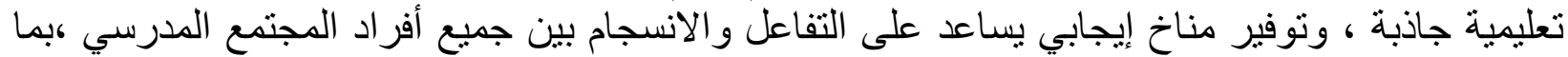

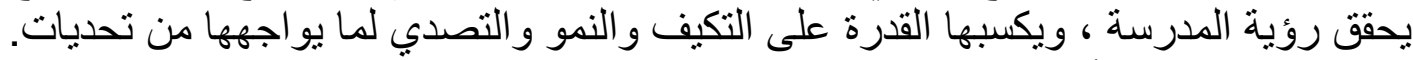

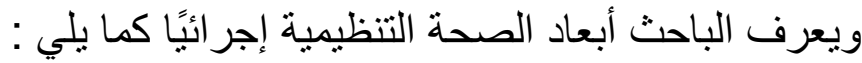

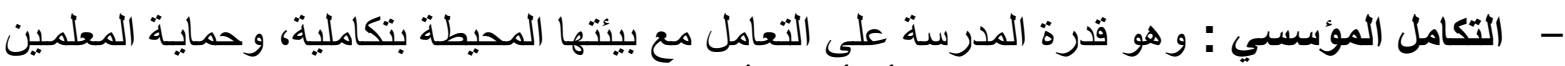

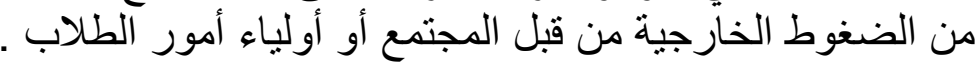


- القيادة بالزمالة: ويقصد بها سلوك القيادة المدرسية الداعمة و الودودة و المنفتحة و التي تتبنى مبادئ

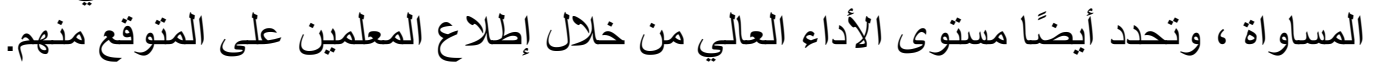

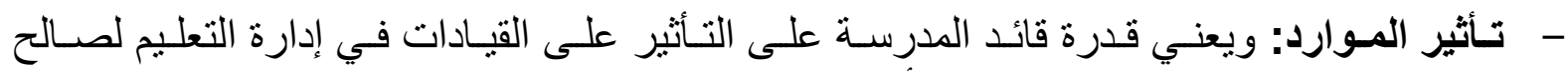

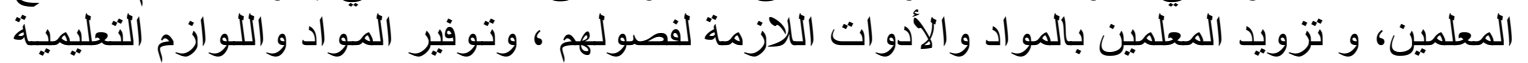
الإضـافية.

- ـ انتمـاء المعلم: وهو شـعور المعلمبن بالانتمـاء والارتبـاط القوي مـع المدرسـة، وشـعور هم بالرضـا

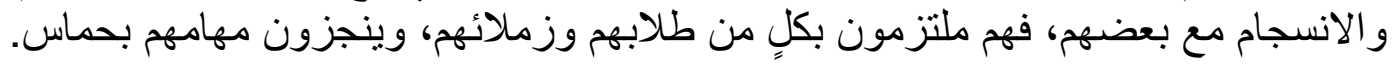

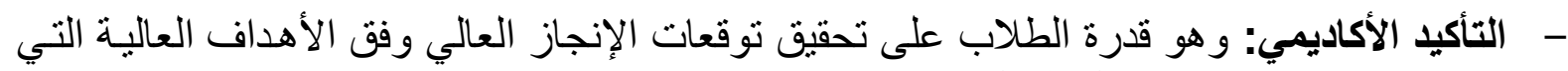

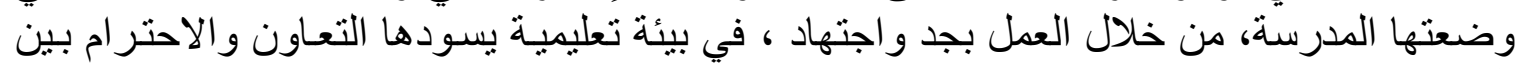
ويحدد مستوى الصحة التنظيمية لمدارس التعليم العام بالارجة التي يحددها المستجيبين من المعلمين على التى التهادي

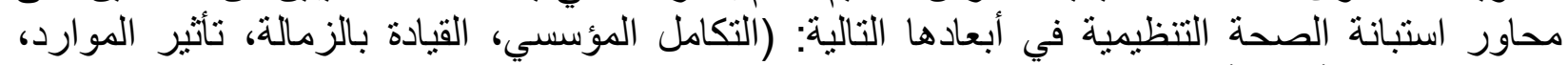
انتماء المعلم، التأكيد الأكاديمي).

أولاً: الإطار النظري

يتضمن الإطار النظري المباحث و الموضو عات التالية:

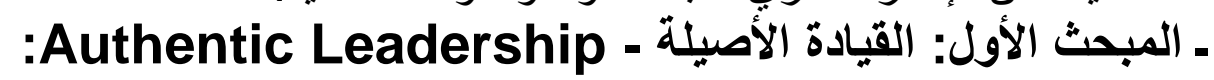
وسوف يتطرق الباحث من خلال هذا المبحث إلى الموضو عات التالية:

• مفهوم القيادة الأصيلة:

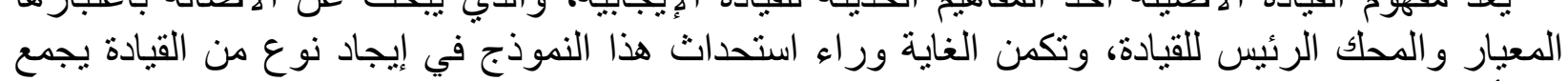

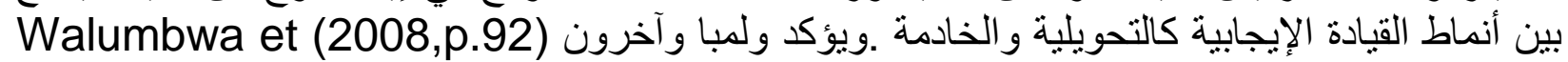
al أن ظهور نظرية القيادة الأصيلة على مدى السنوات العديدة الماضية هو نتاج لتقاطع القيادة والأخلاق

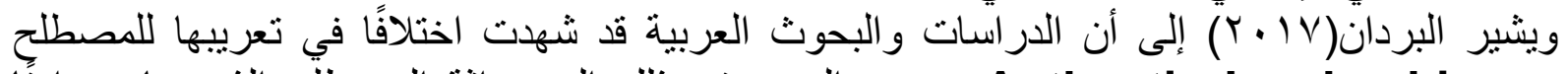

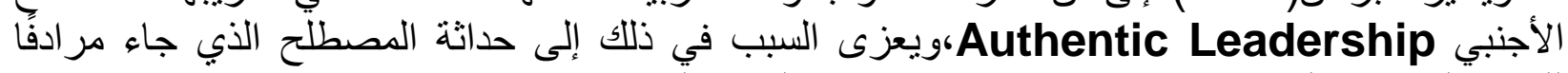

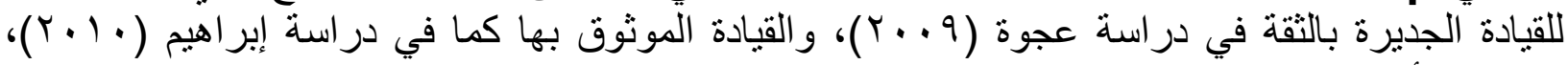

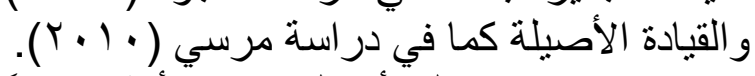

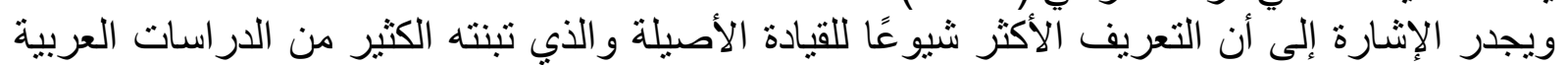
و الأجنبية قد وضعه ولمبا وآخرونسWalumbwa et al (2008,p.94، حيث أنثار فيه إلى أبعاد القيادة

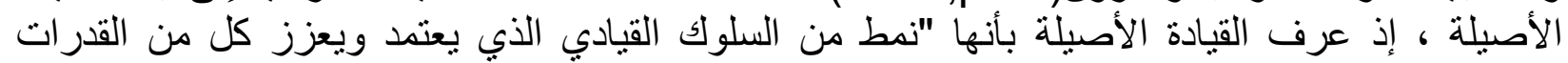

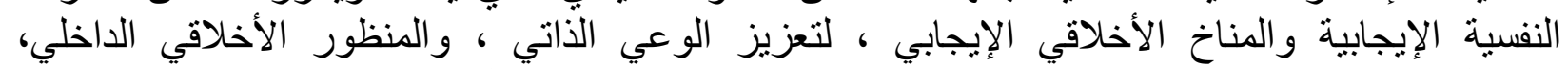

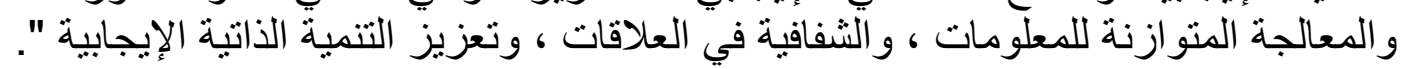

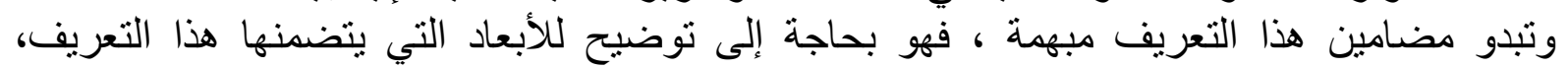

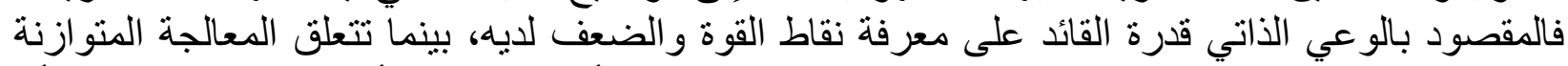

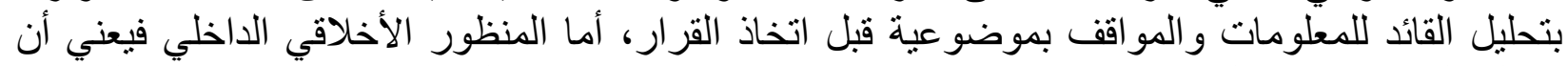

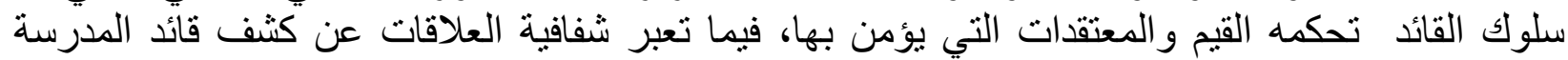

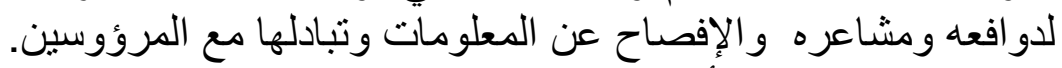

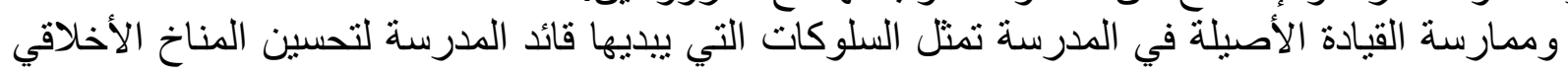

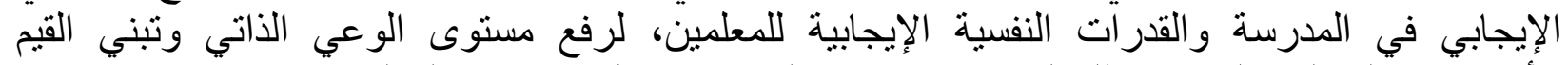

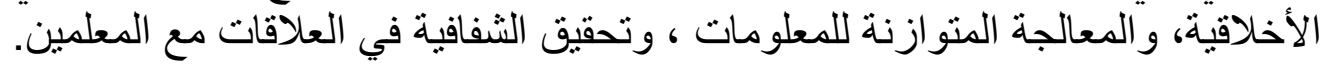




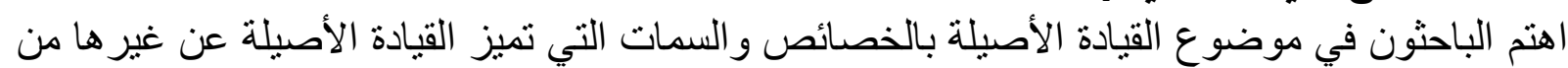

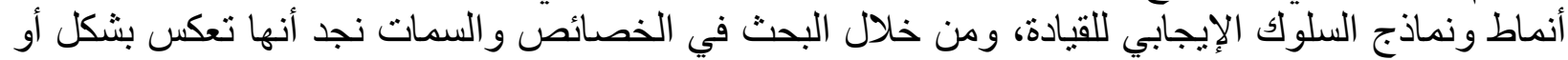

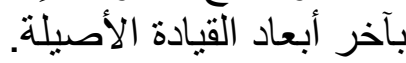
ويمكن تحديد ما تعرضت التباد له الدراسات السابقة حول خصائص القيادة الأصيلة ، والتي أوردها البردان

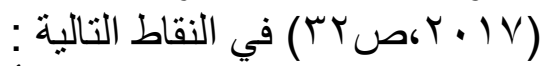

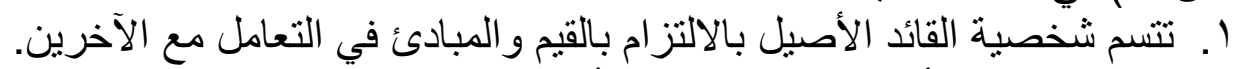

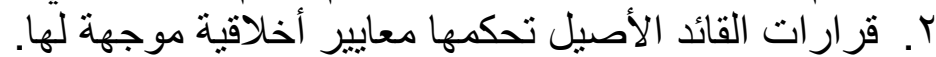

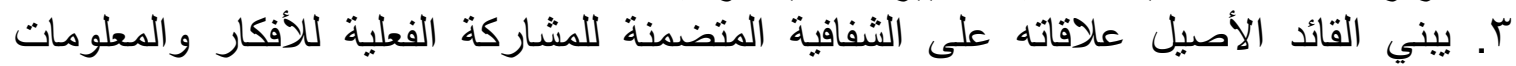

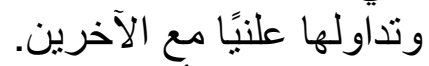
ع. يظهر القائد الأصيل النزائنة العالية وتطابق الأقوال والأفعال، وعدم التأثر بالضغوط عند

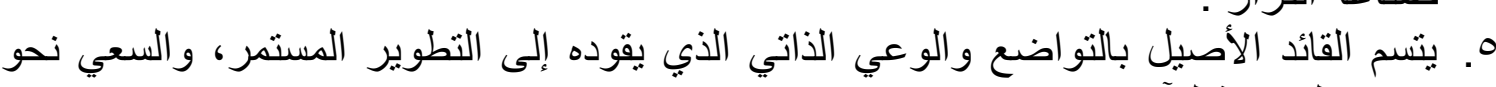
تحقيق الرفاهية للآخرين.

7. . يسعى القائد الأصيل إلى بناء الثقة المتبادلة مع العاملين ضمن إطار قئيمي و أخلاقي.

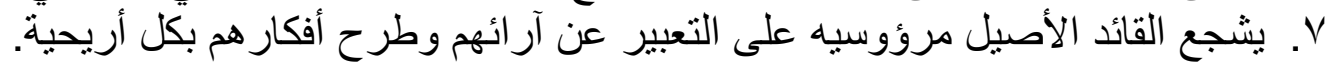

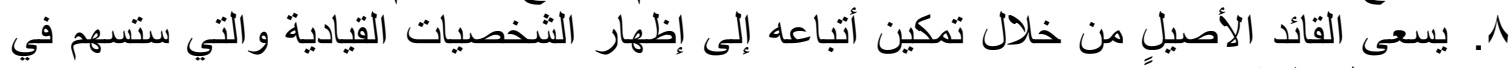
قيادة المنظمة مستقبلًا. وتأسيسًا على ما سبق يمكن القول بأن أهم خصائص القيادة الأصيلة التي يجب نوافرها لدى قائد

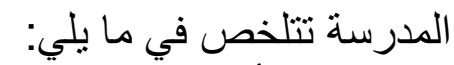
- - أن يعيش قائد المدرسة حالة من التعلم المستمر، فهو يعي تمامًا المهارات التي ينبغي عليه اكتسابها. ـ ـ أن يكون قائد المدرسة قادرًا على التحليل الموضوعي للمعلومات، والاستماع لجميع الآراء

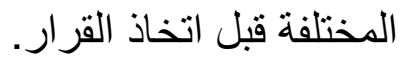

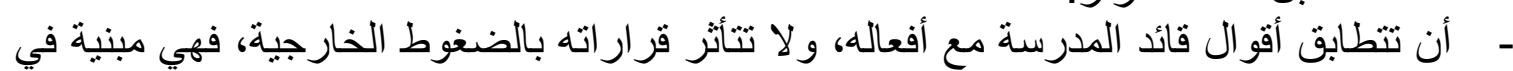

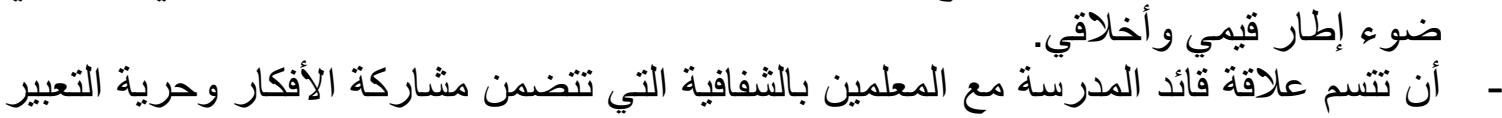
في جو من الثقة والاحتر ام المتبادل.

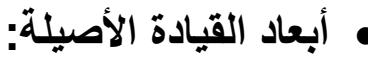

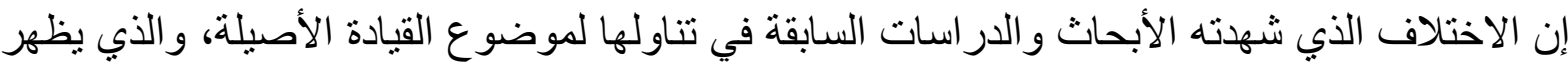

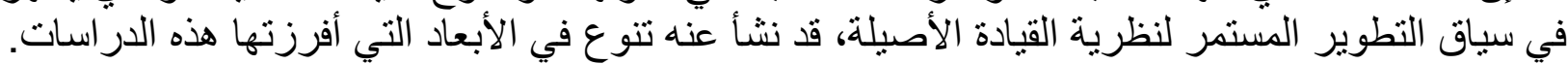

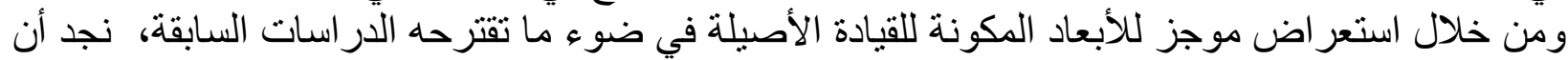

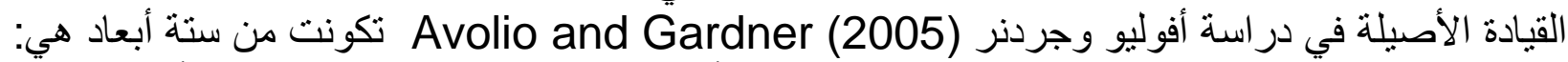

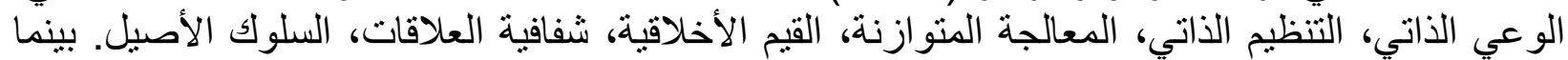

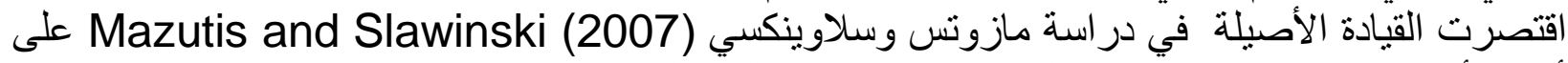

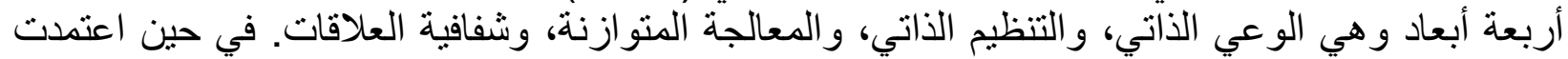

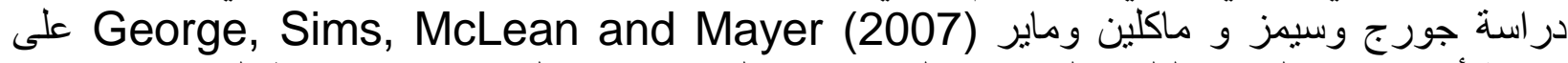

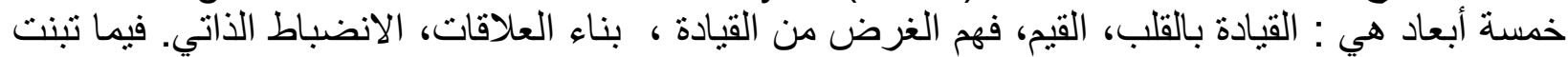

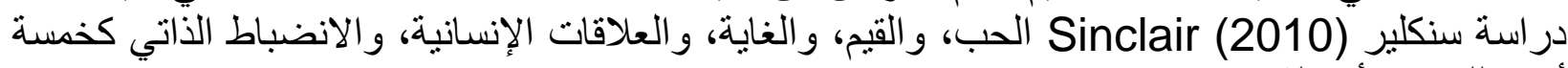
أبعاد للقيادة الأصيلة.

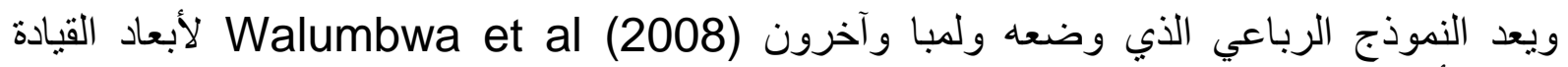

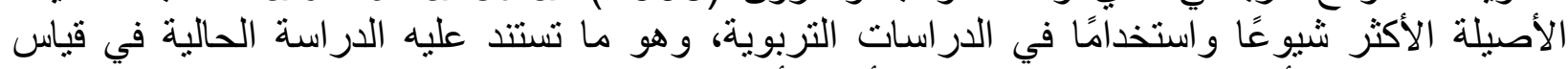

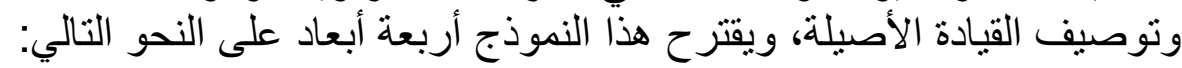




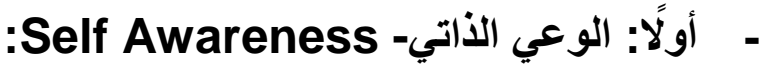

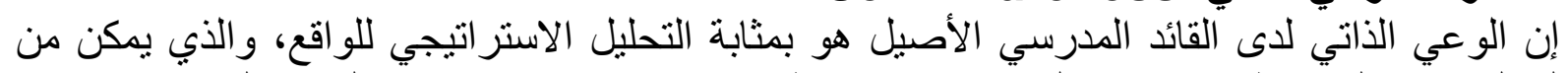

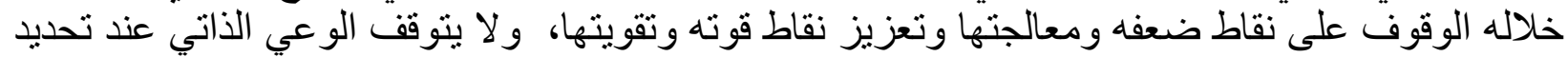

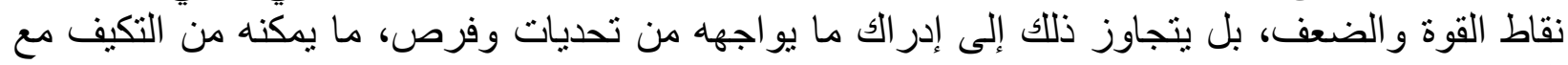

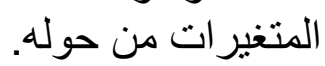

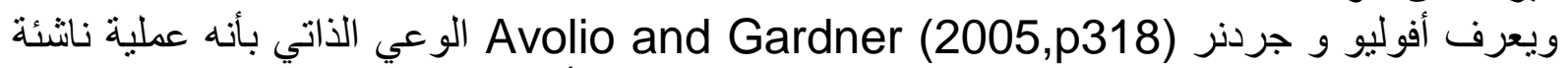

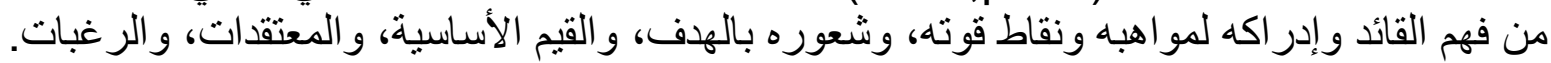

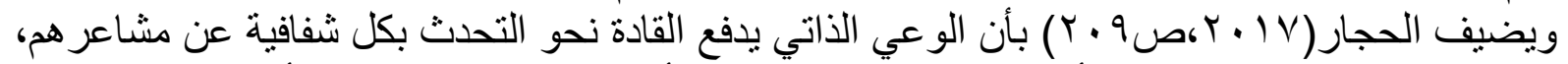

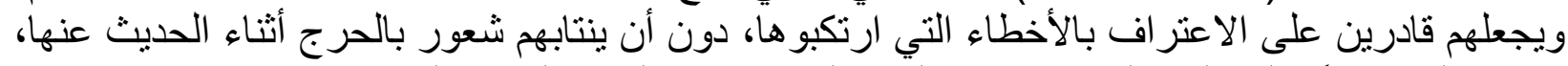

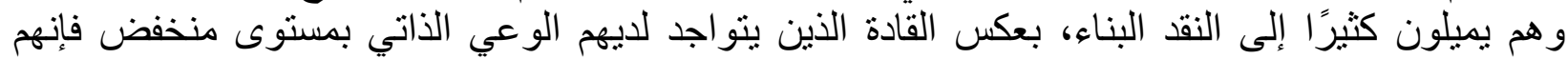

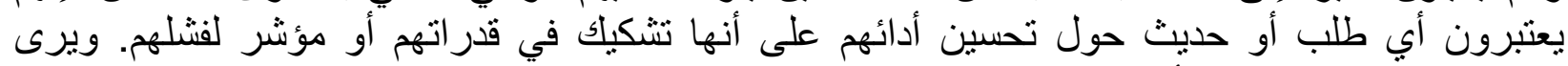

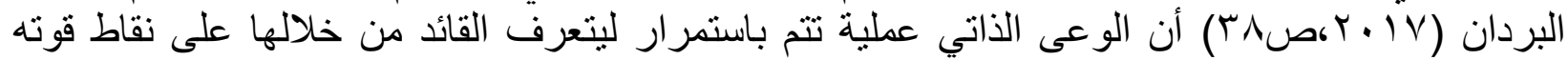

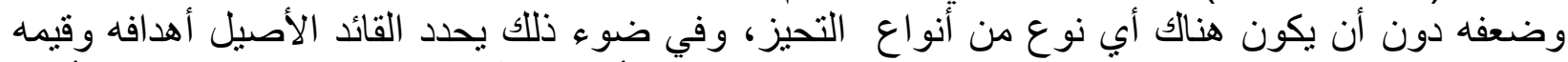

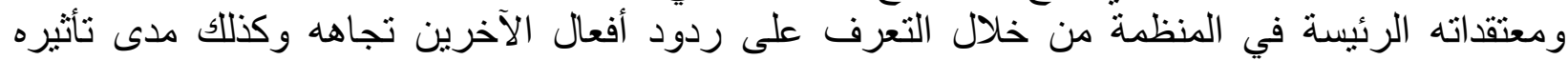

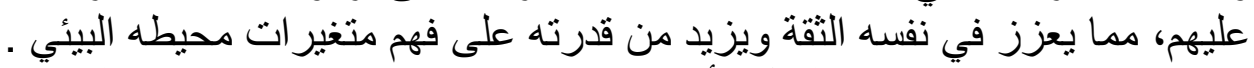

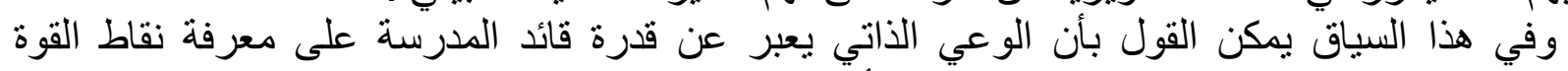

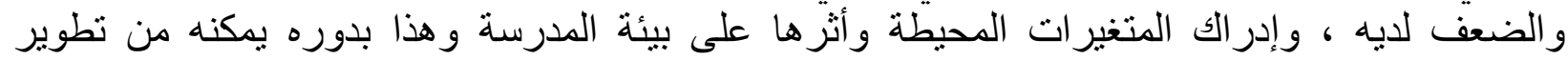

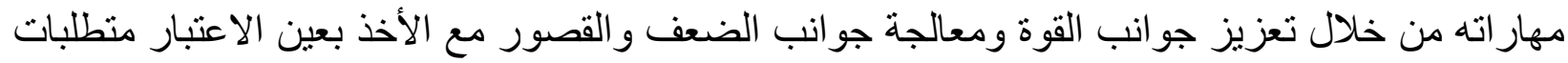

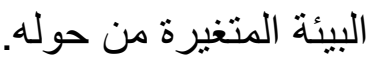

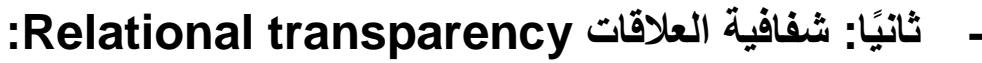

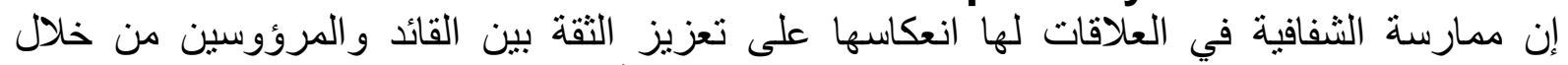

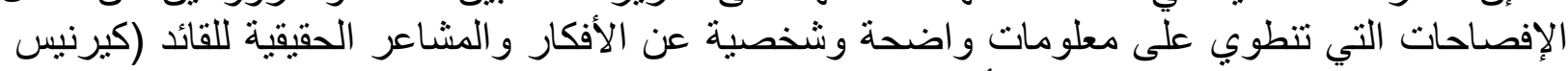

Kuruoz (2017,p.448) (Kernis, 2003,p.3 , Sagnak and

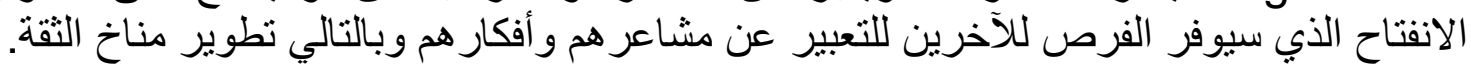

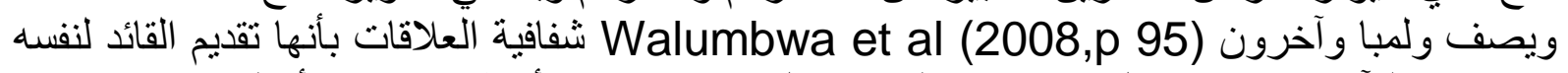

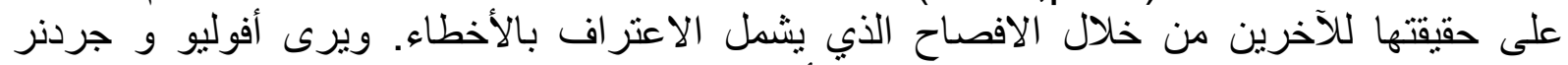
Avolio and Gardner (2005,p.317)

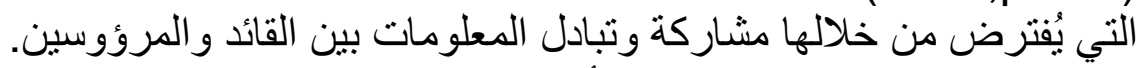

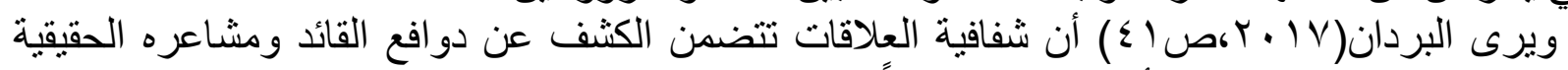

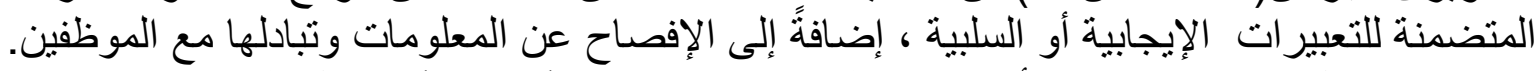

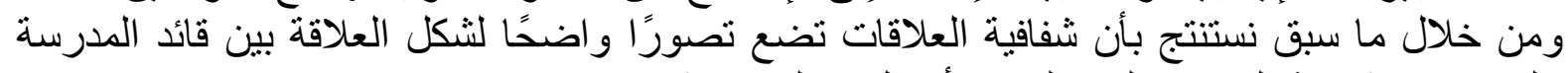

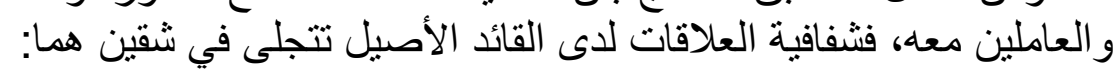

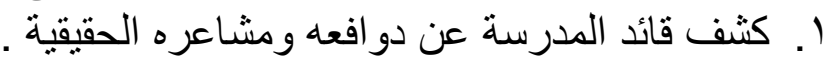

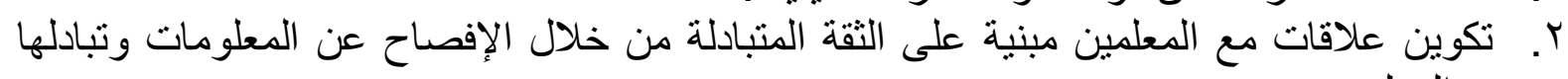

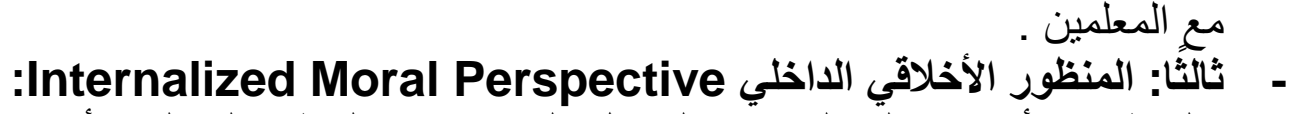

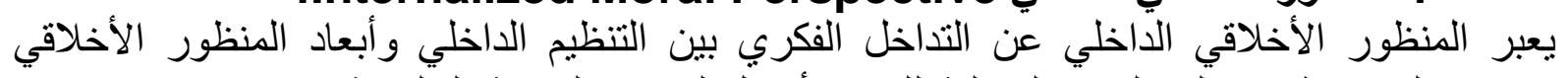

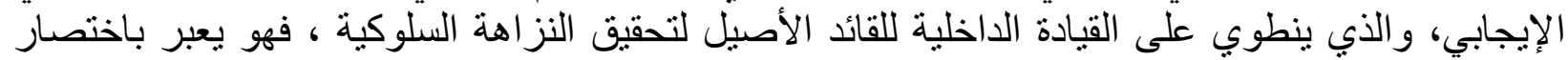

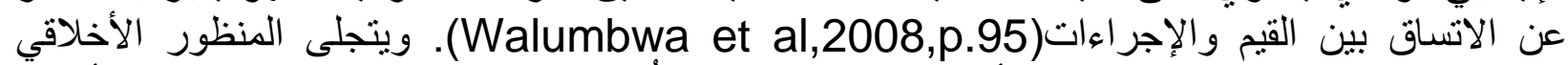
الداخلي في كونه بسترشد بالمقاييس الأخلاقية الداخلية ، التي تُشتخدم في تنظيم سلوك الفرد بنفسه (أفوليو وآخرون, Avolio et al,،2009,p.424. ويعتى القائد الأصيل على القيل القيم الأخلاقية الداخلية في مواجهة الضغوط الجماعية والتنظيمية و المجتمعية، فاتخاذ القرارات والسلوكات التي يبديها القائد الأصيل تتسق مع قيمه الداخلية (ولمبا 


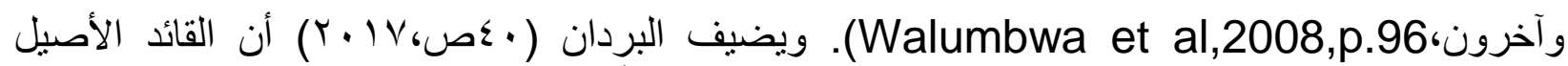

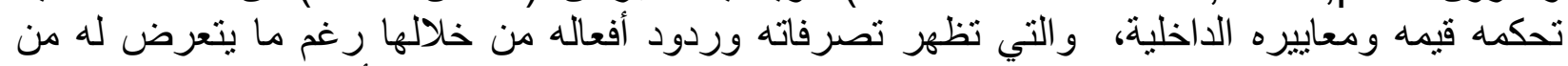

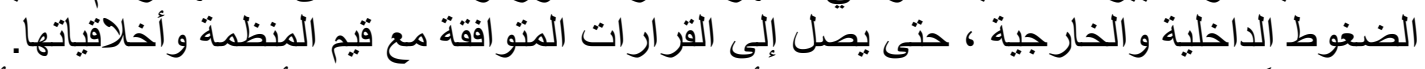

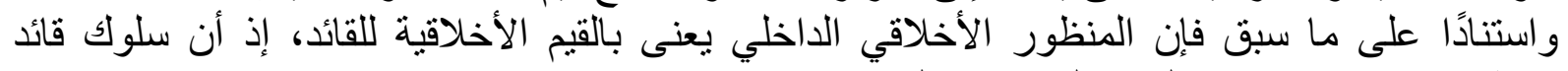

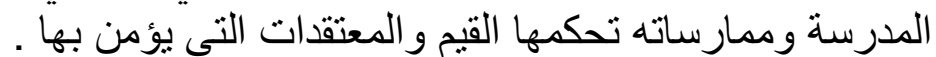

:Balanced Processing -

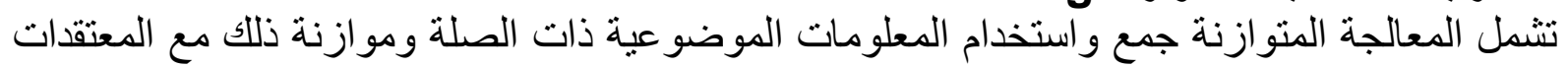

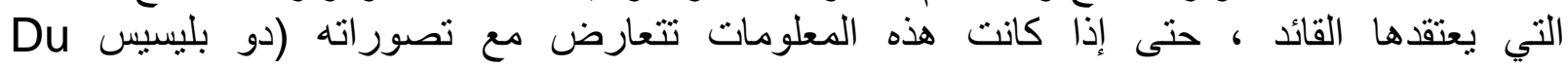
.(plessis,2014,p.59, وتثتير المعالجة المتوازنة إلى تحليل موضوعي للبيانات ذات الصلة قبل اتخاذ القرار (أفوليو

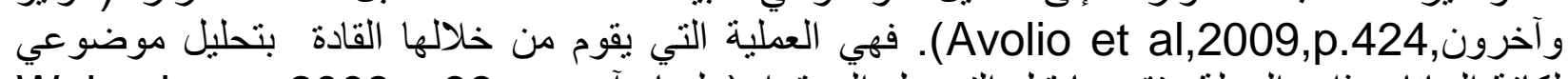

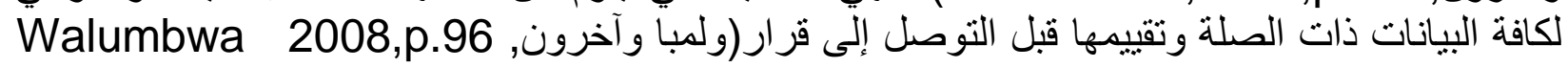
.(et al, ويعرف درويش ورزاي (et al مarvish and Rezaei) 2011,p.430 المعالجة المتوازنة بأنها العملية

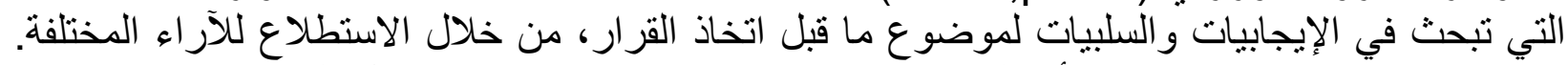

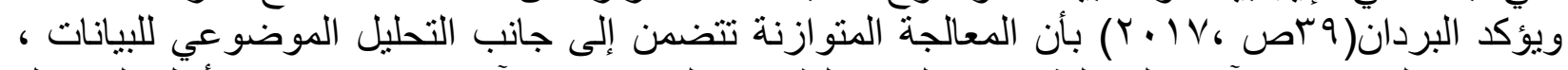

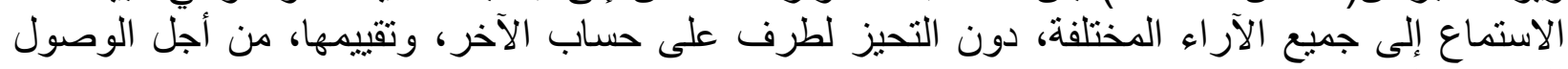
للقر ار السليم.

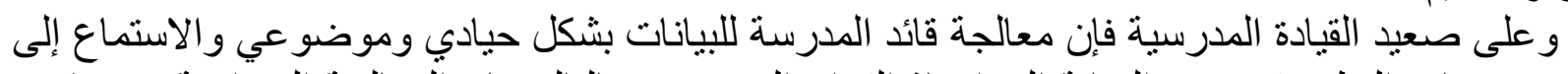

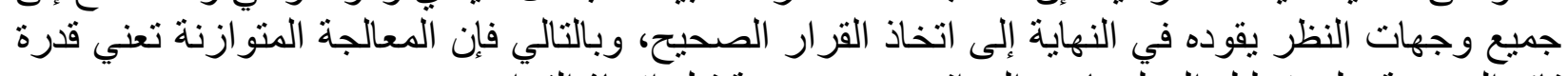

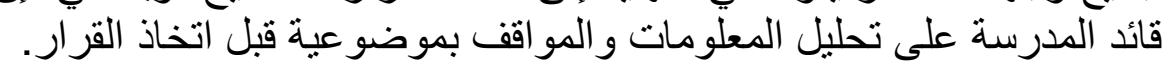

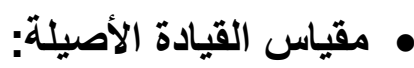

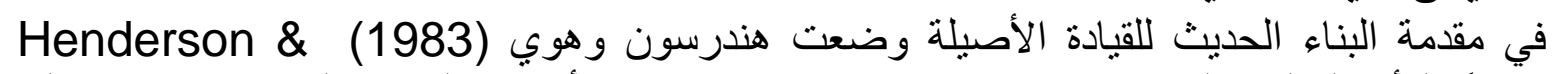

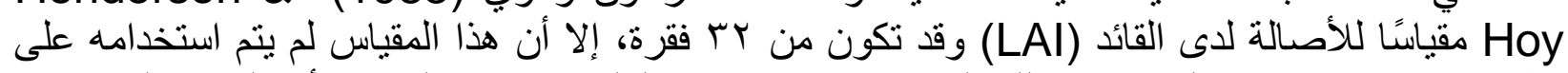

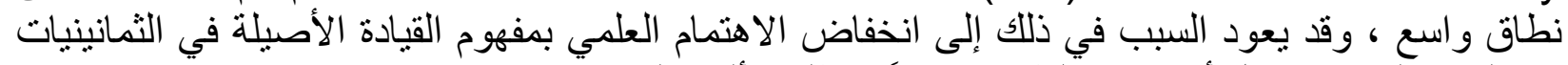

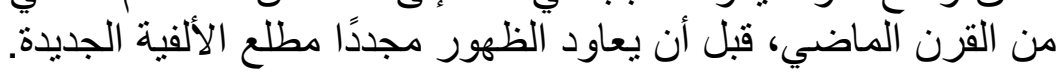

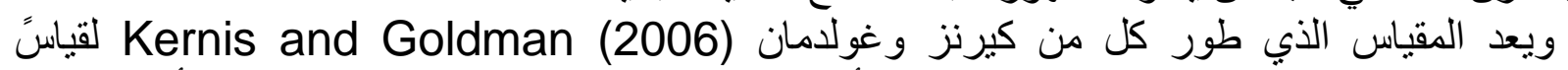

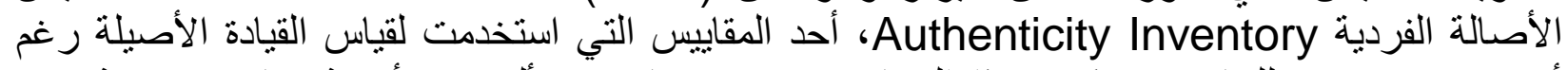

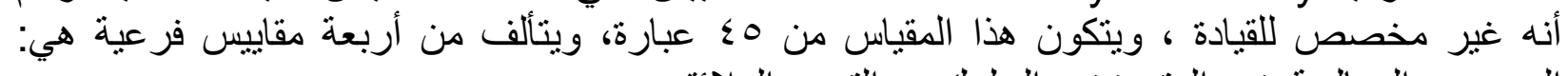

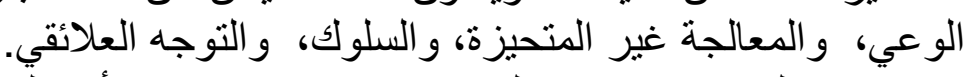

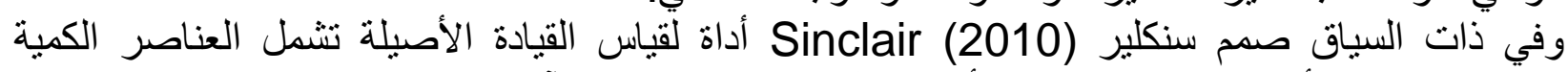

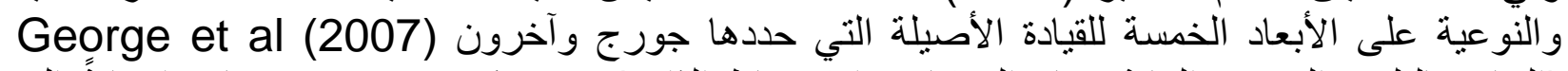

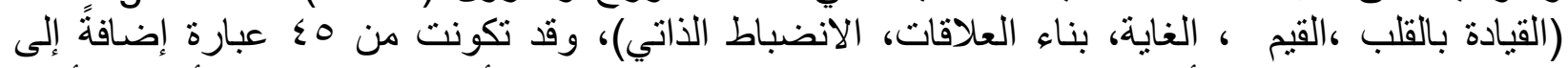
عبار ات مفتوحة لجميع الأبعاد الخمسة بحيث يمكن للمجييين تقديم تعليقات أو شرح استجاباتياتهم أو تقديم أمثلة

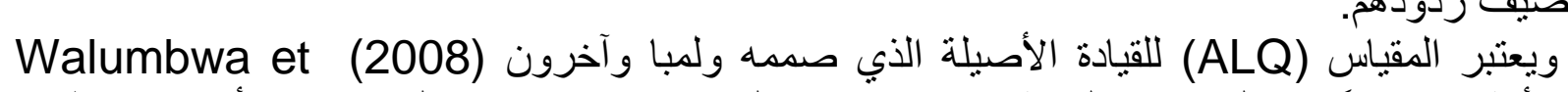

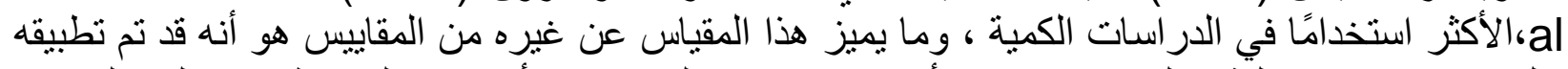

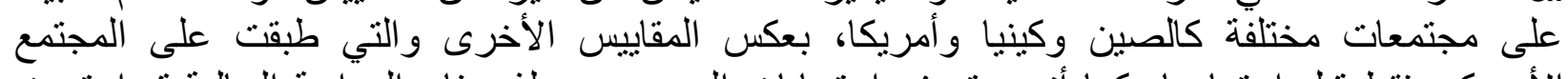

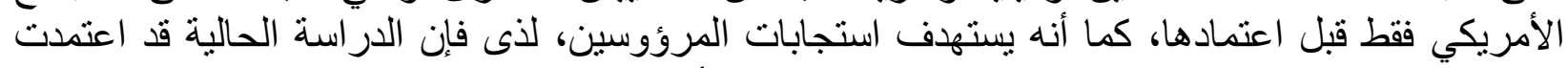

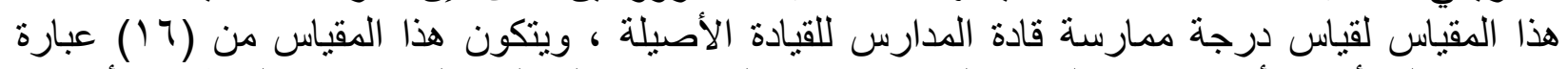

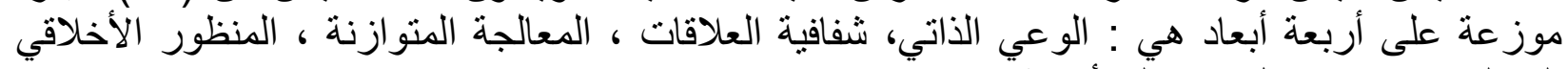
الداخلي ، ويحتوي كل بعد على أربعة فقرات التئ 


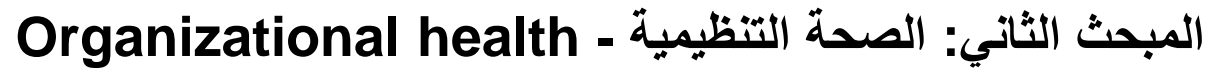

\author{
وسوف يتطرق الباحث من خلال هذا المبحث إلى الموضو عات التالية:
}

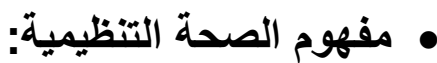

عرف ولف Wolff (2003,p7) الصحة التنظيمية بأنها ما تقوم به المنظمة من إجراءات تهدف

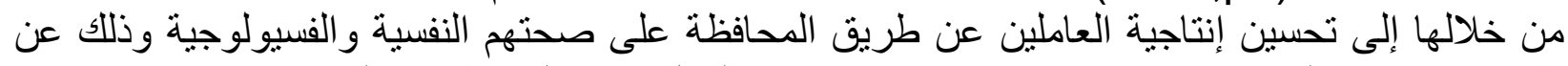

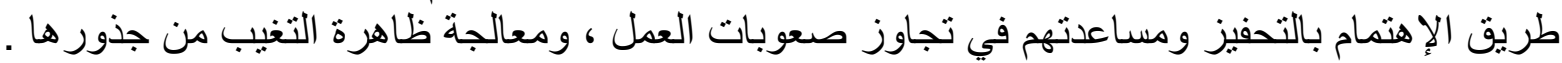

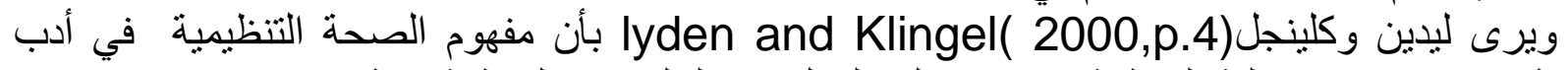

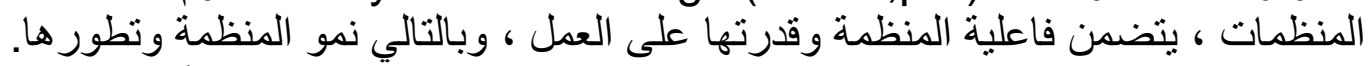

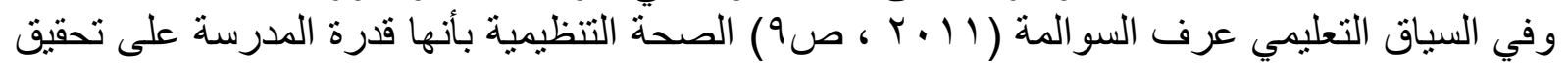

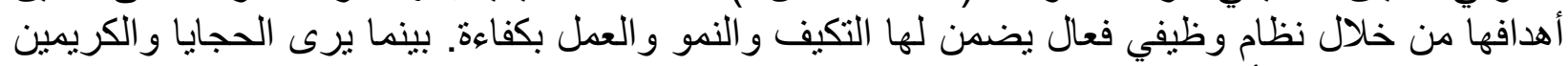

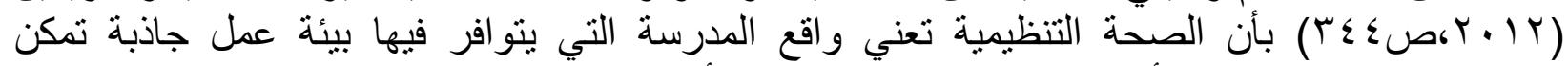

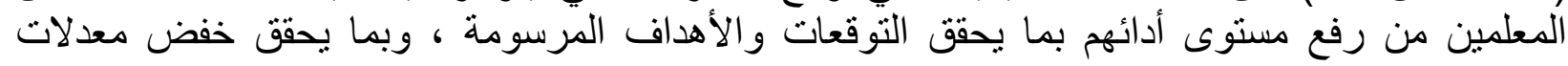

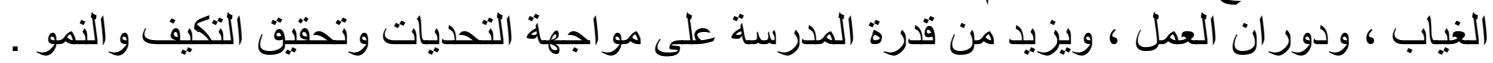

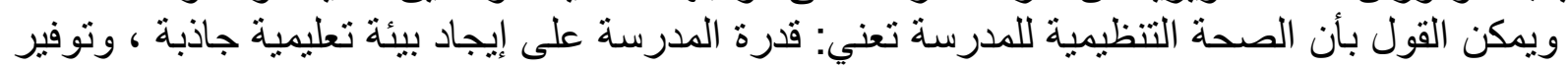

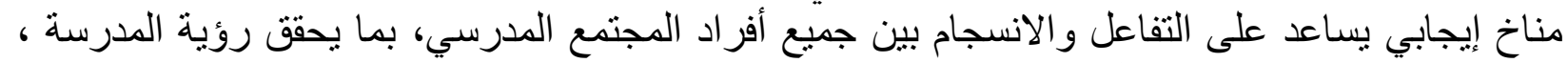
ويكسبها القدرة على التكيف و النمو والتصدي لما يو اجهها من تحديات.

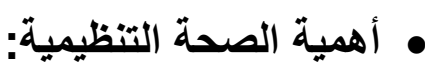

تكمن أهمية الصحة التنظيمية كما تراها وولف Wolff (2003) في كونها تعالج بفعالية الأسباب

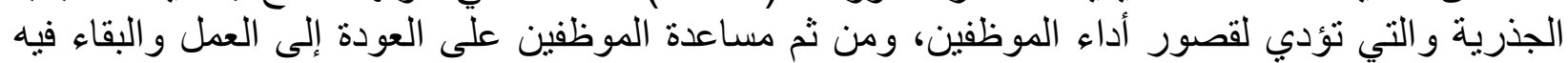

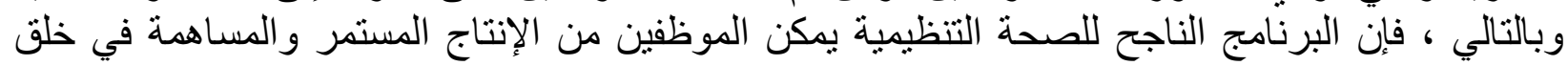

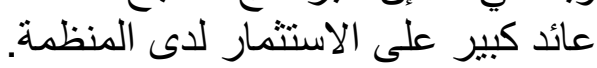

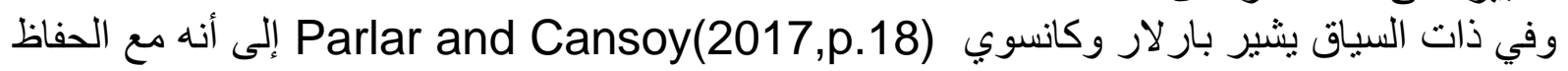

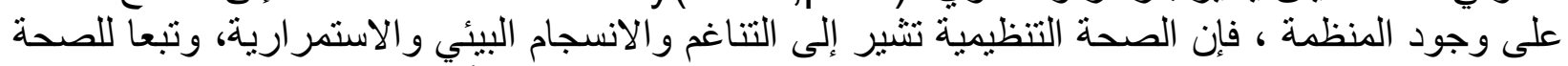

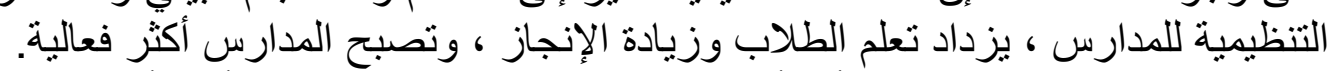

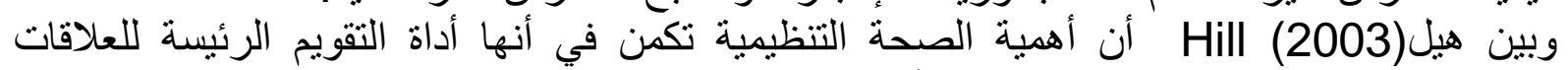

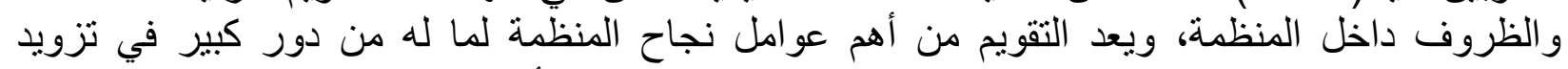

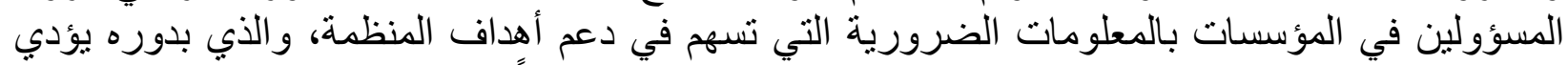

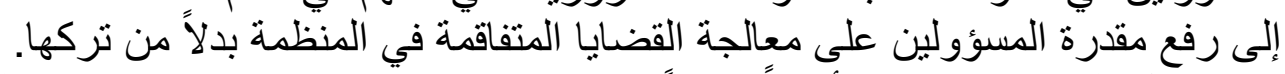

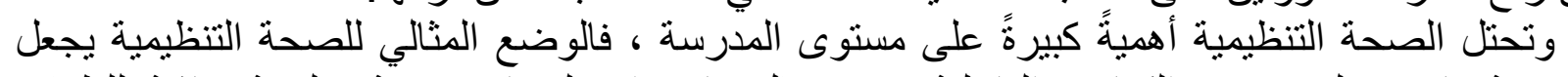

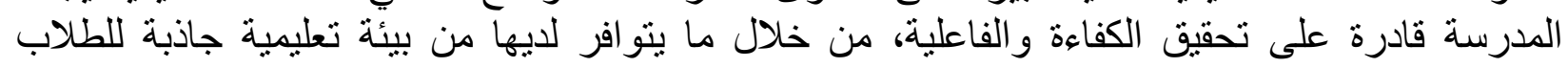

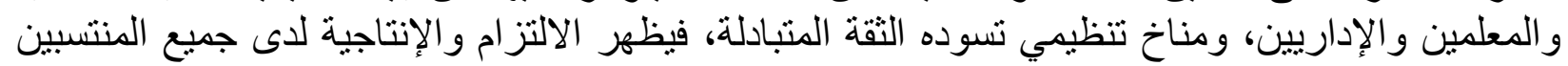

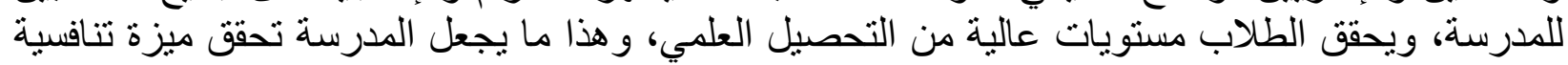
على أقر انها من المدارس الأخرى.

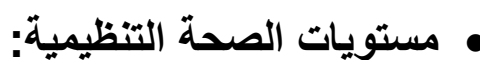

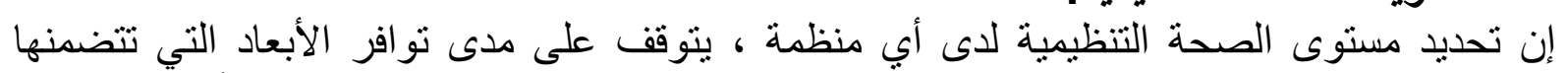

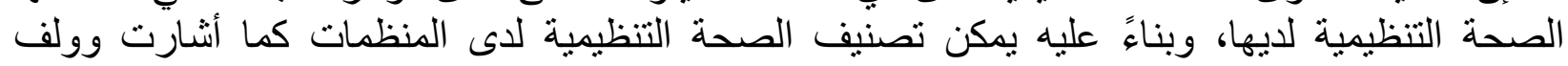

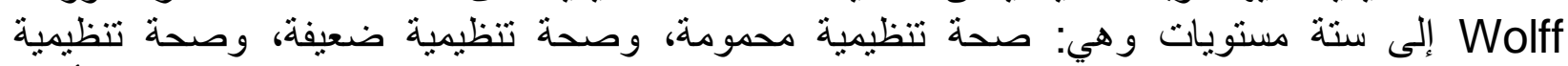

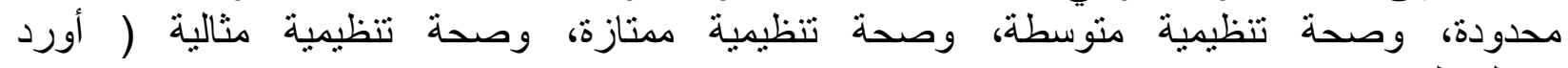

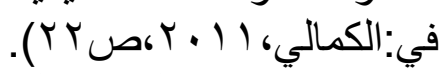

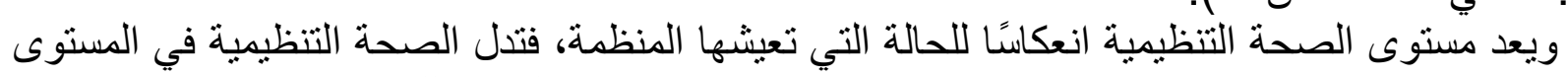

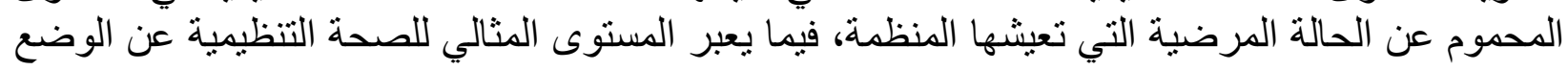




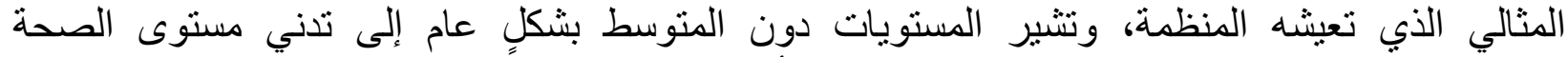

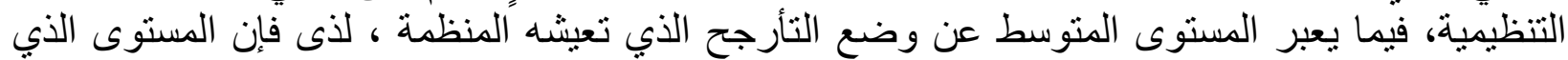

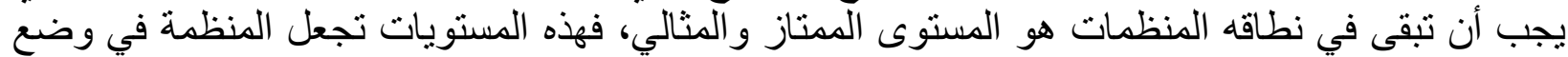

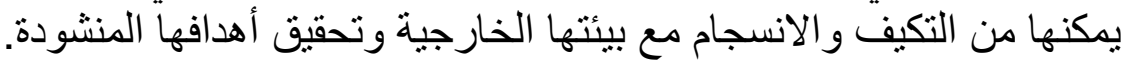

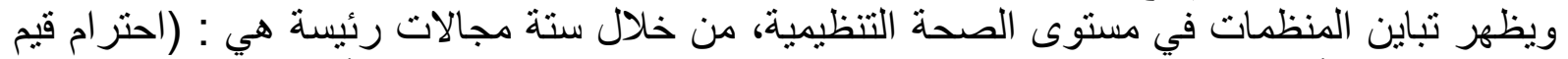

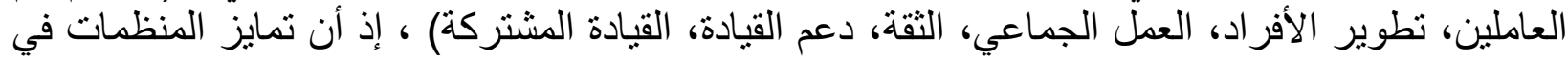
تناولها لهذه المجالات يؤدي للتباين في مستوى الصحة التئ التنظيمية (لواب, Luab,2004 ).

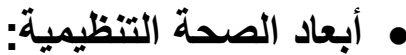

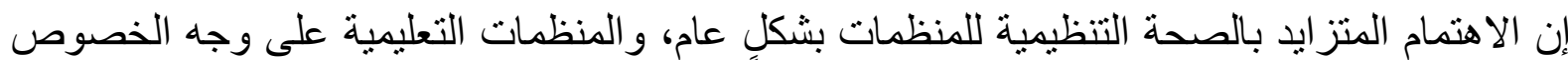

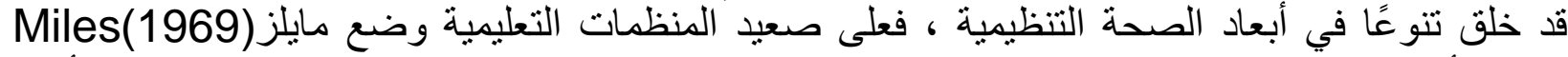

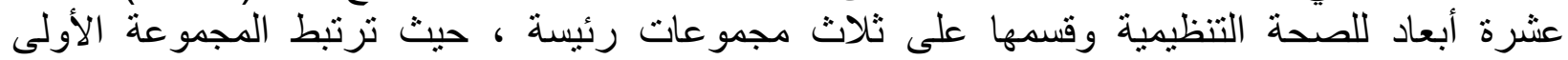

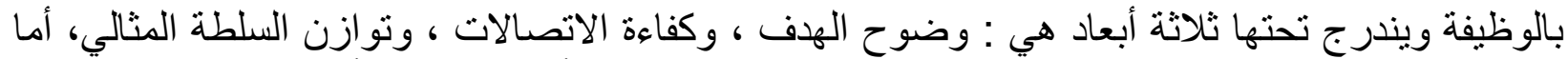

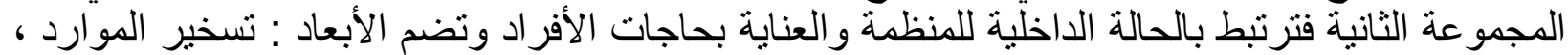

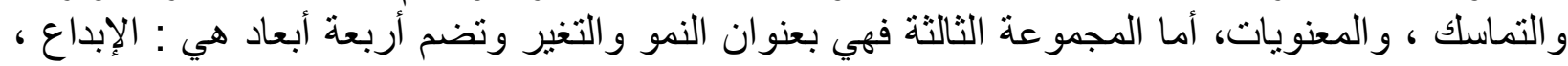
و التكيف ، و الاستقلالية ، وملاعمة حل المبات المشكلات

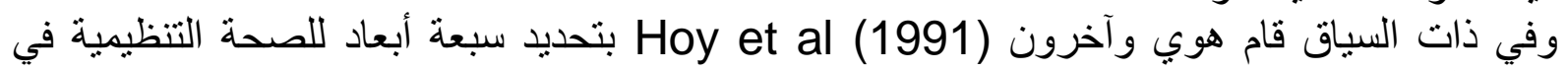

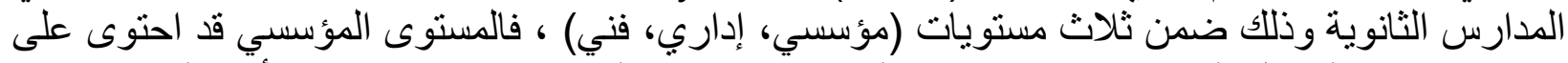

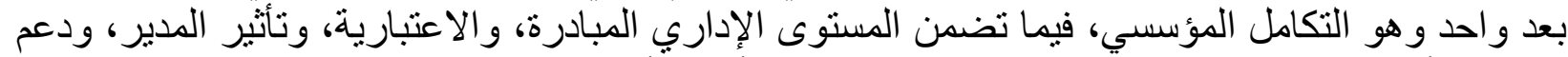

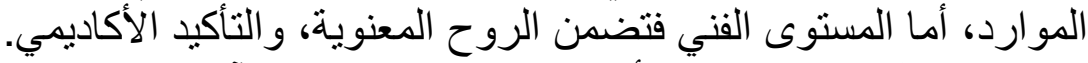

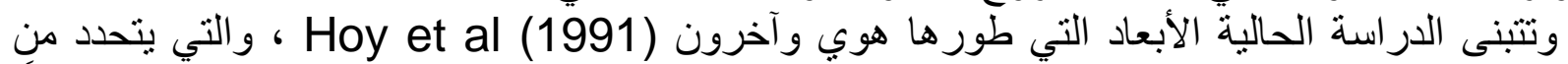

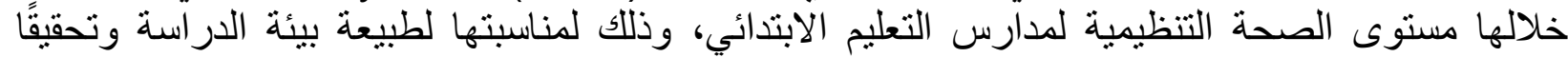

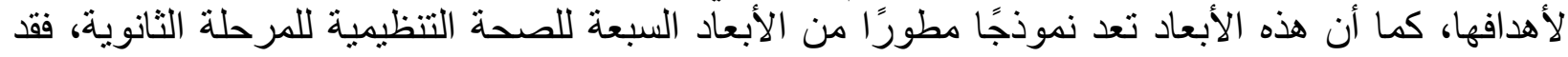

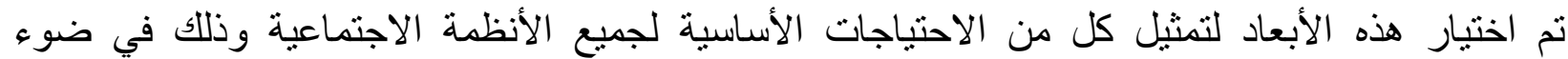

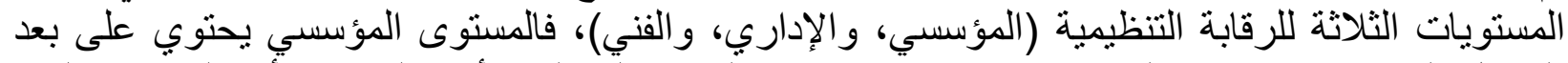

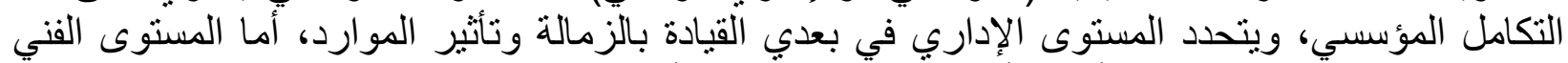

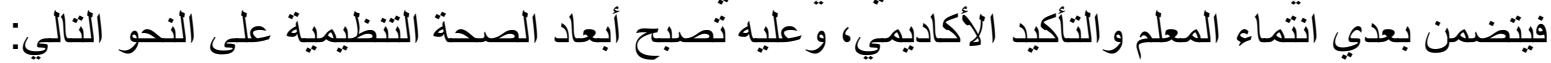

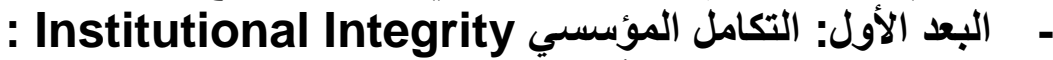

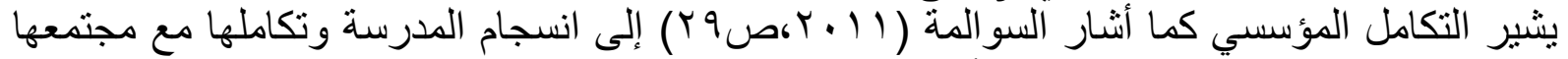

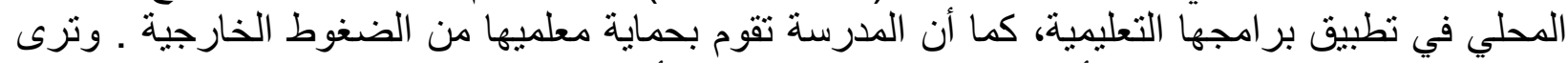

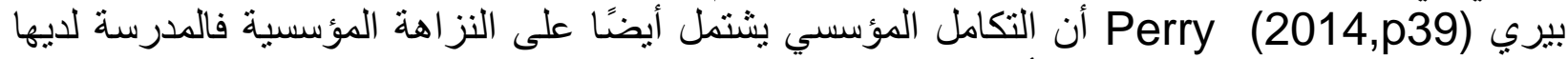

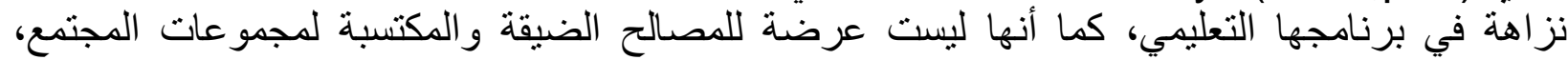

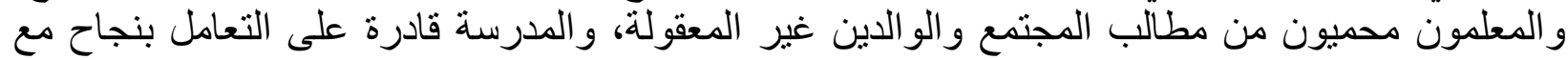

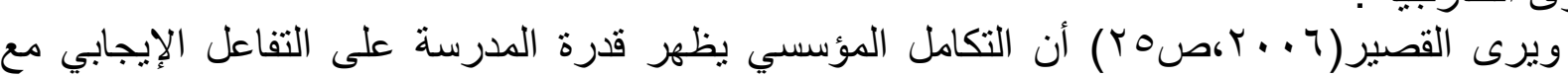

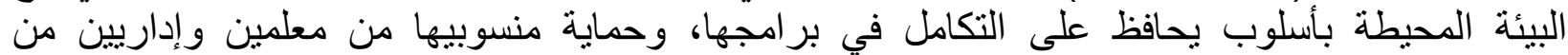

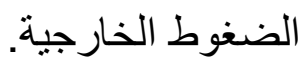

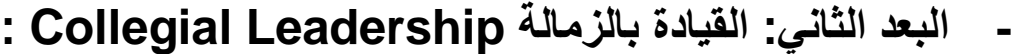

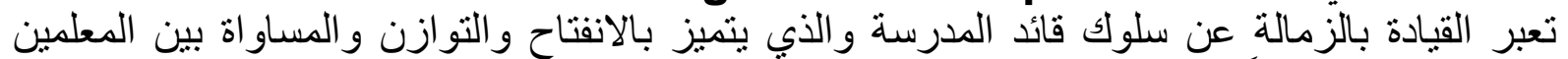

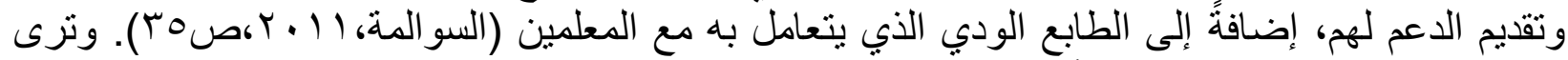

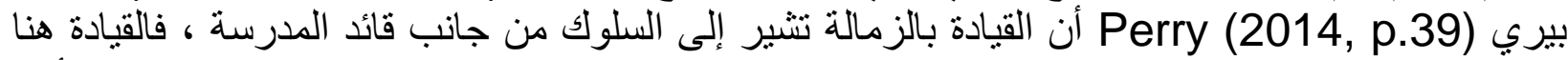

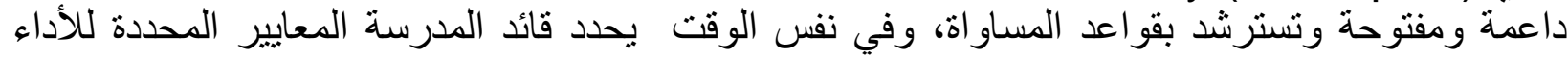

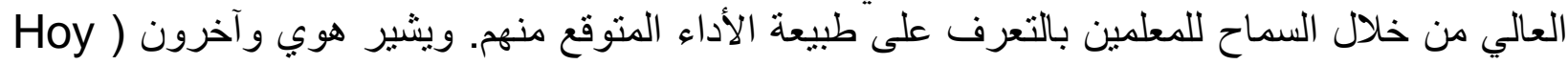


et al (1991,p.163 إلى أن القيادة بالزمالة تجمع بين الدعم الاجتماعي للمعلمين، وتحديد المعايير المحققة لأهداف المدرسة.

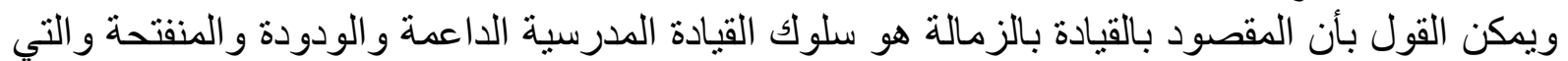

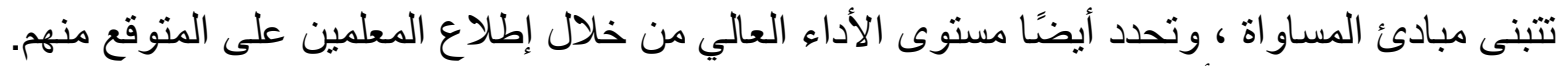

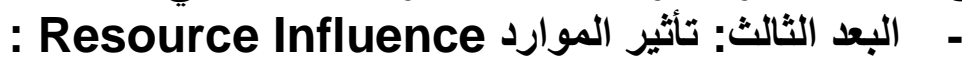

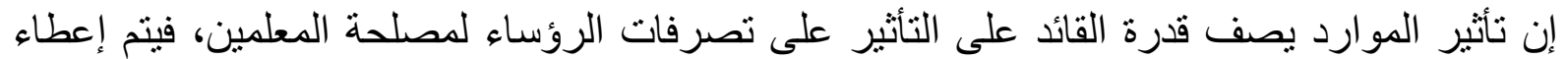

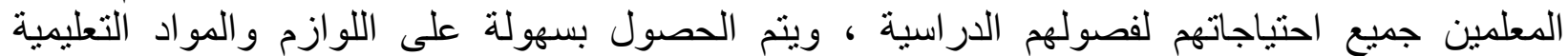

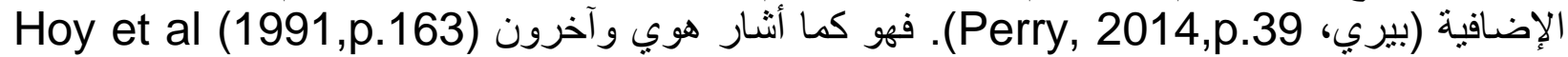

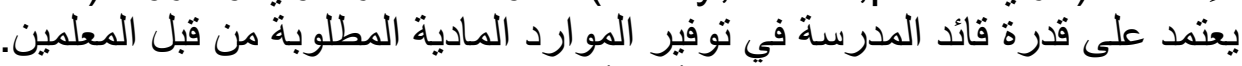

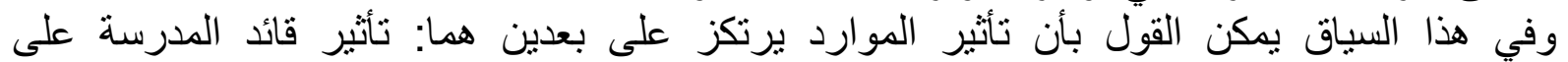

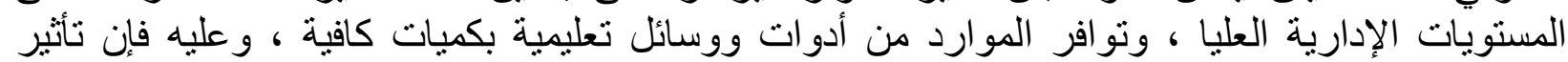

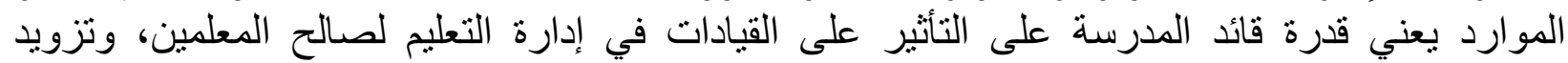

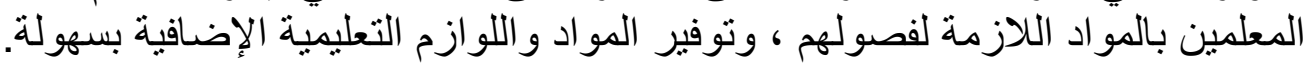

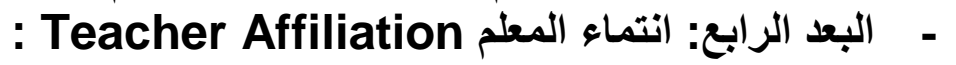

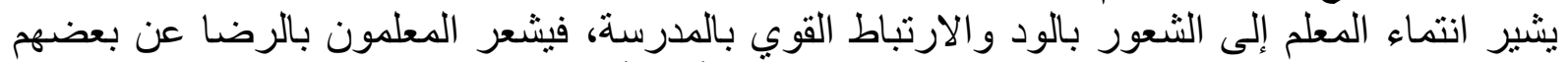

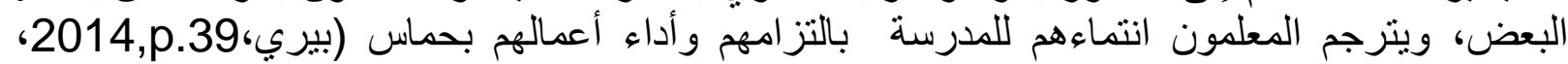

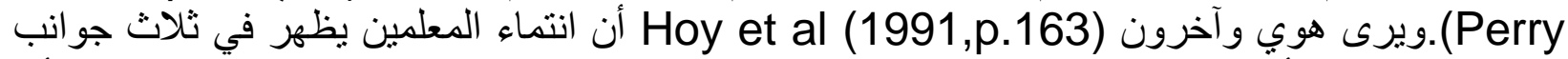

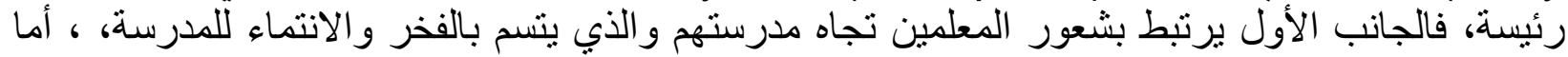

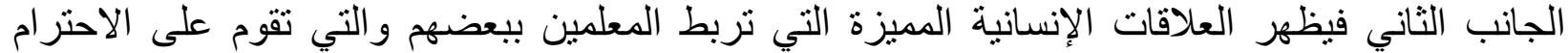

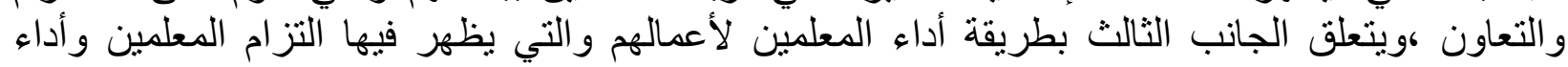

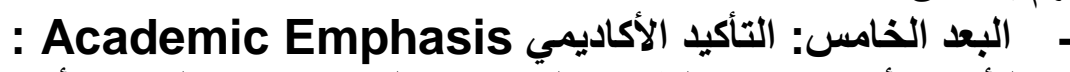

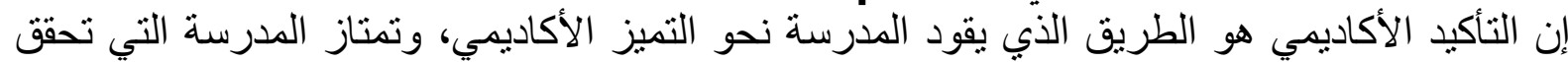

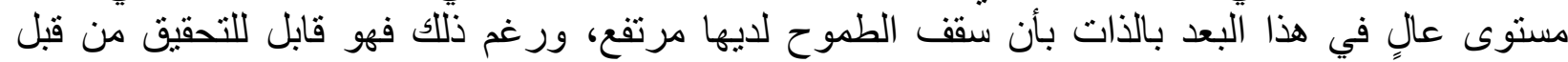

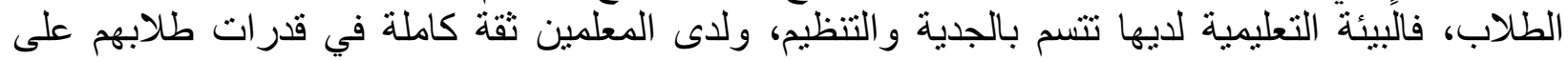

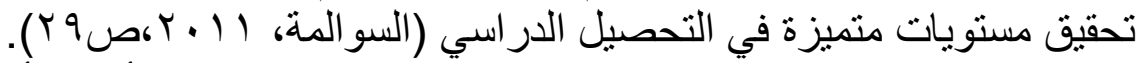

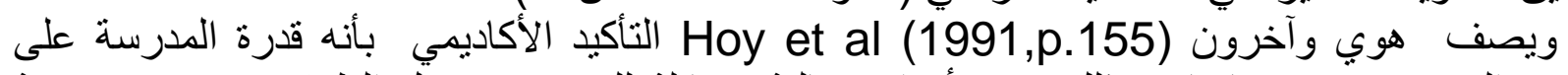

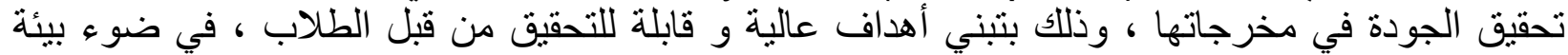

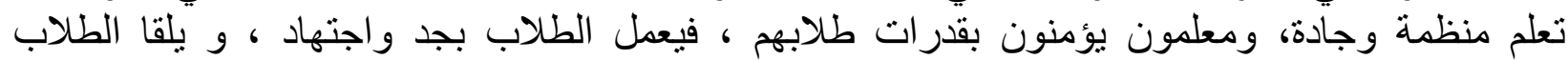
المتفوقون التقدير و الاحتر ام من زملادئهم.

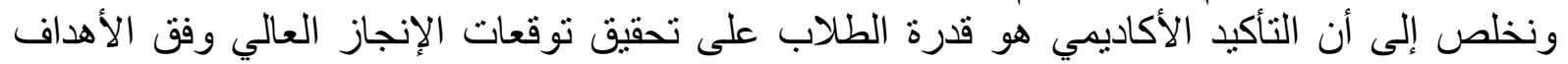

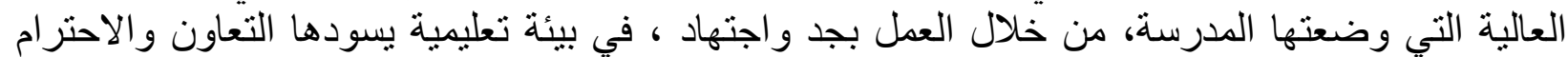

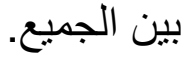

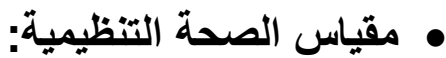

رغم تعدد مقاييس الصحة التنظيمية إلا أن هناك مقاييس خاصة بقياس الصحة التنظيمية للمدارس ،

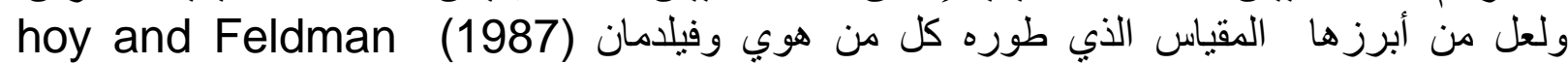

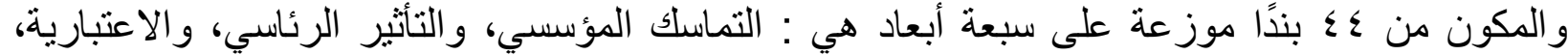

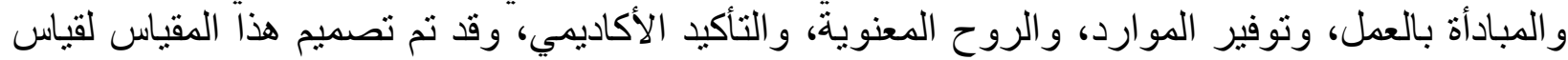

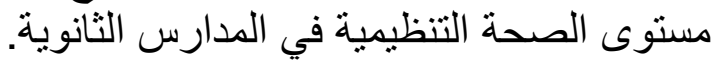

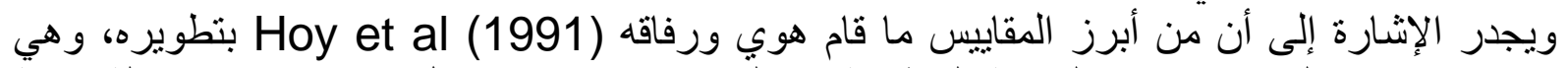

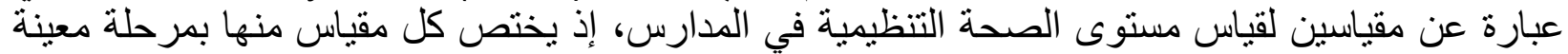

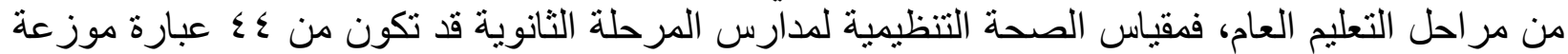

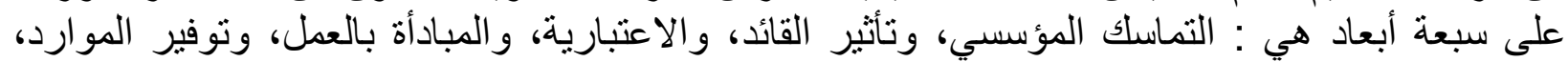




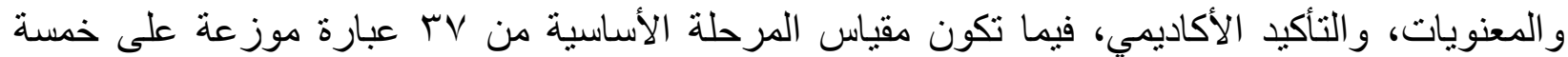

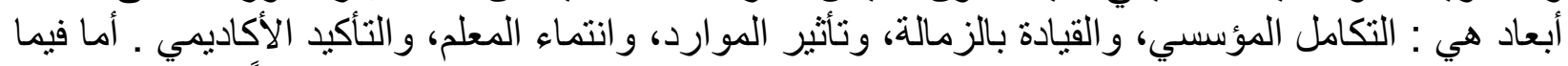

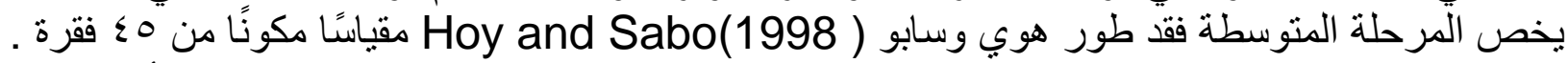

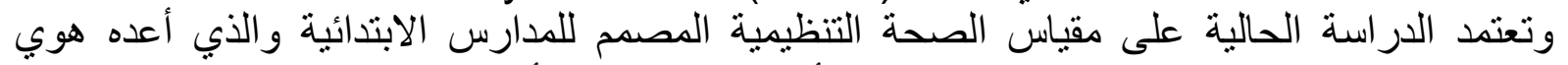

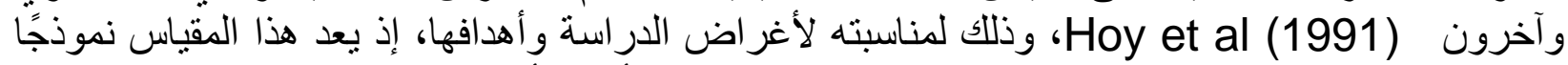

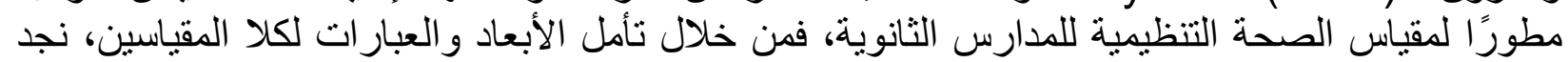

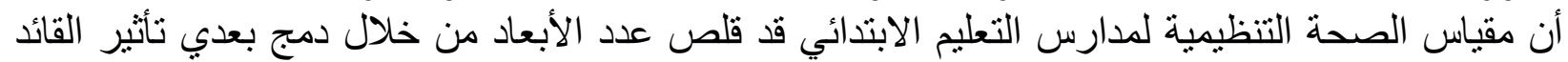

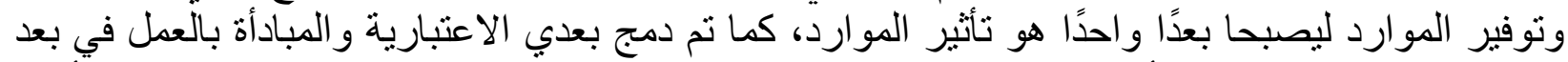

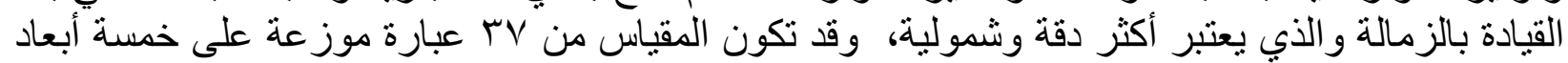

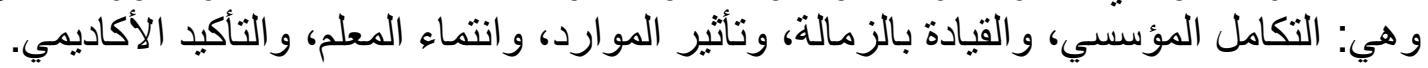

\section{نموذج تصوري لطبيعة العلاقة بين القيادة الأصيلة والصحة التنظيمية:}

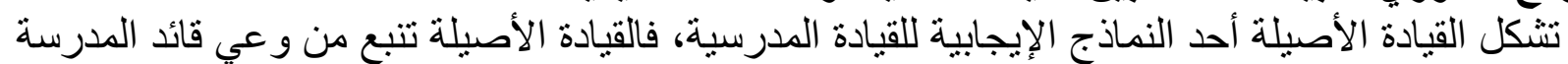

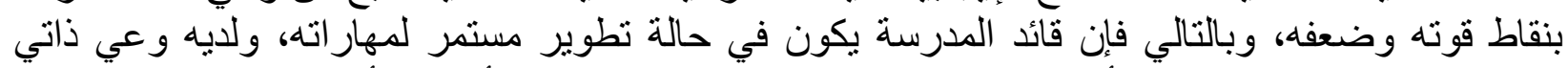

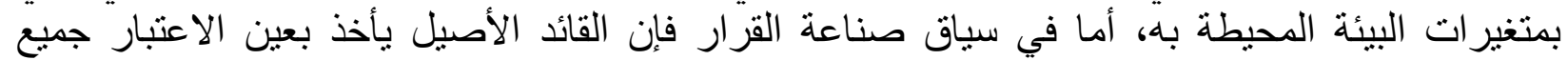

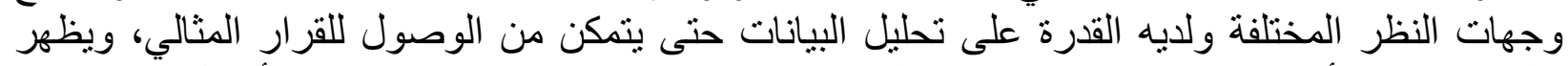

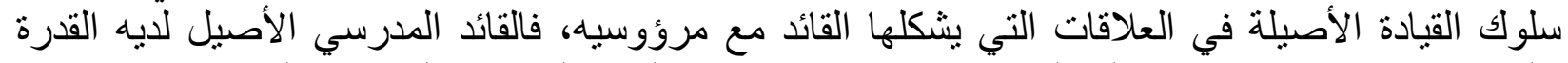

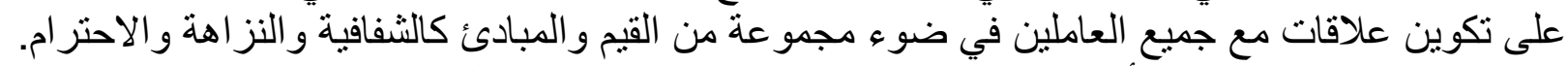

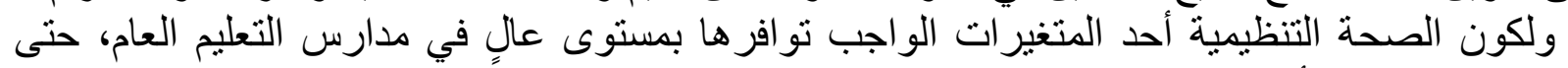

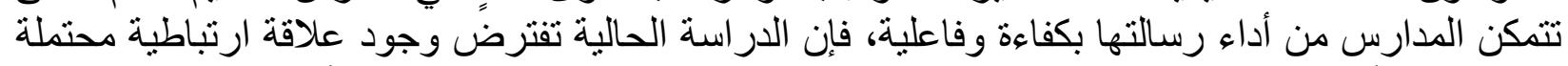

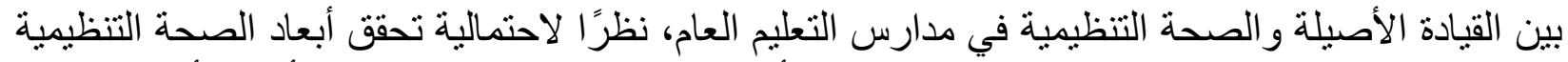

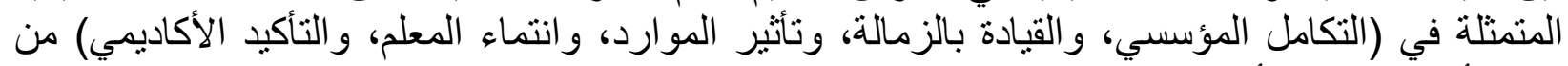

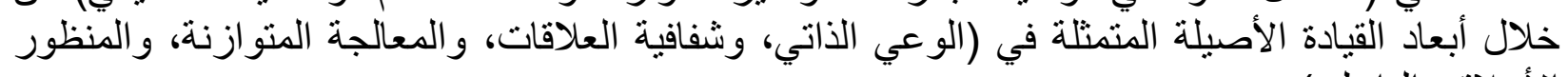

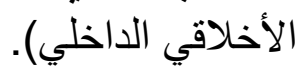

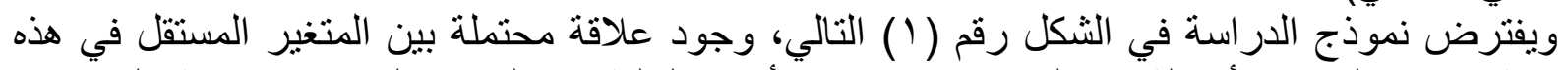

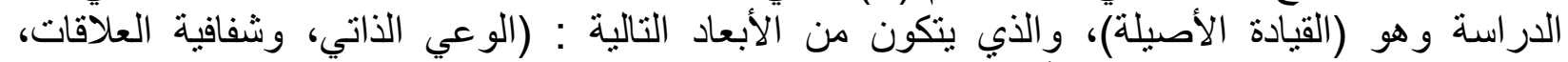

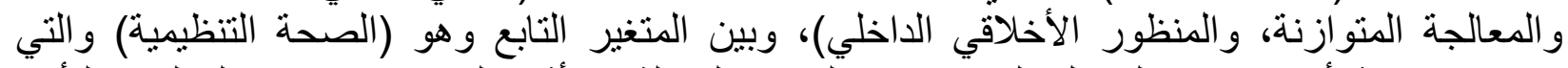

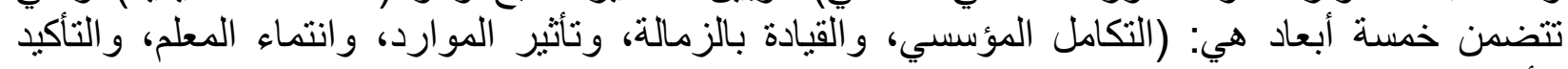
(الأكاديمي)

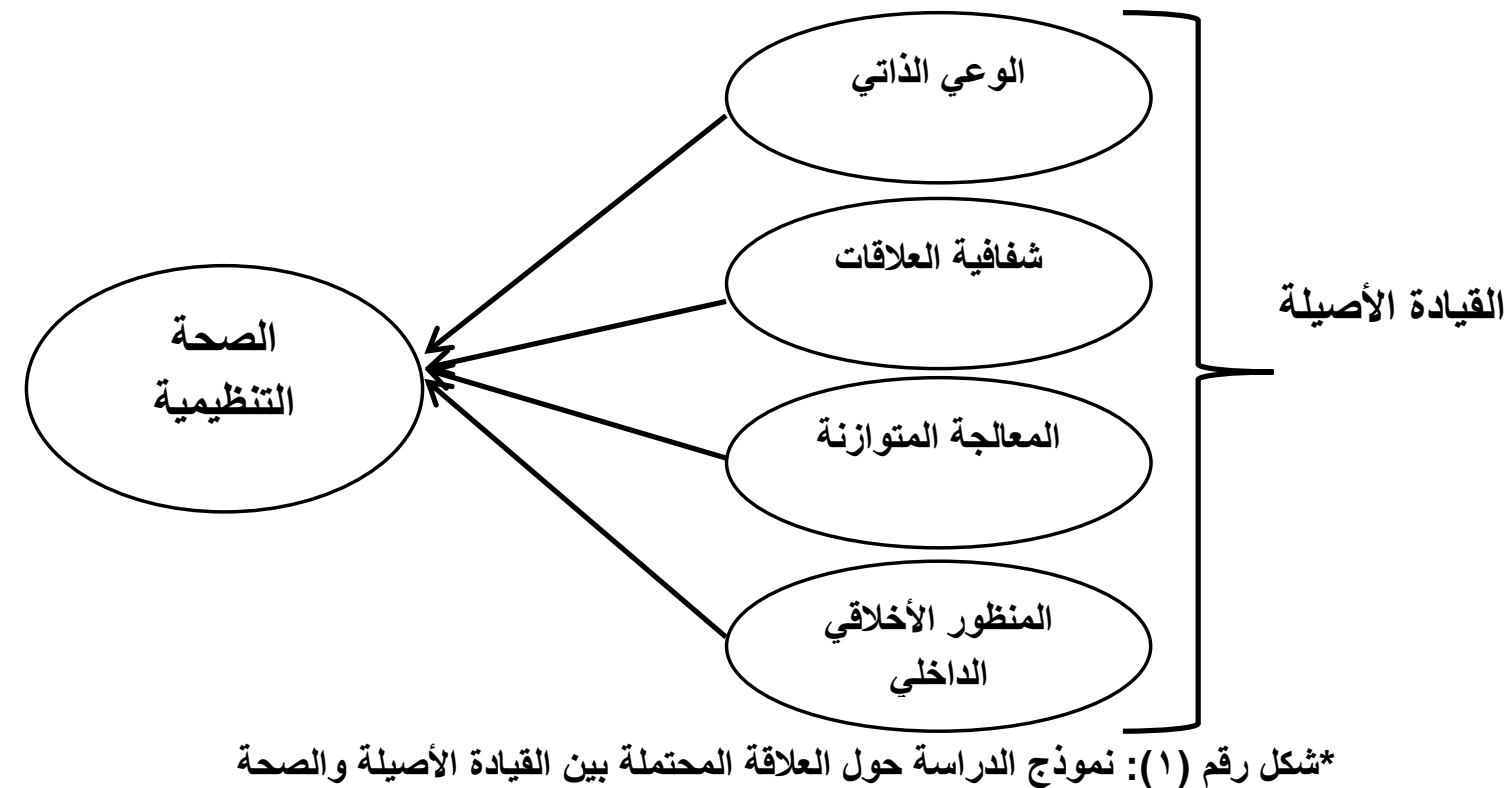




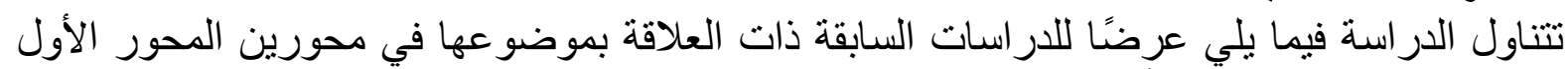

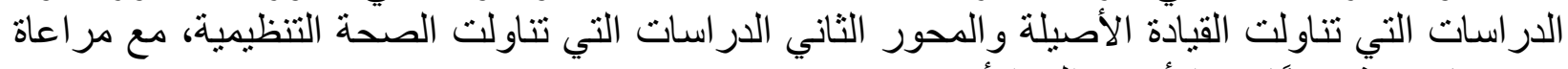
عرضها مرتبة زمنيًا من الأحدث إلى الأقدا.

\section{• من المحور الأول : دراسات متعلقة بالقيادة الأصيلة:}

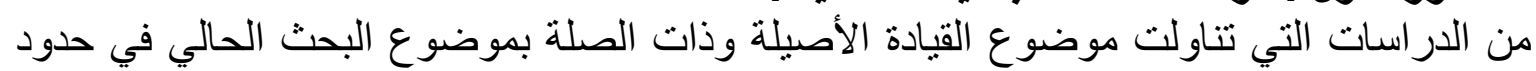
علم الباحث ما يلي : -

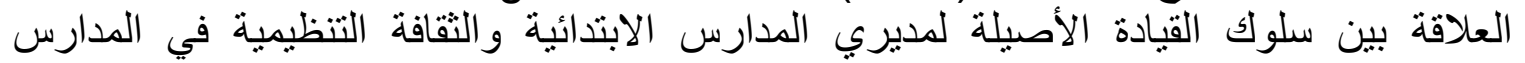

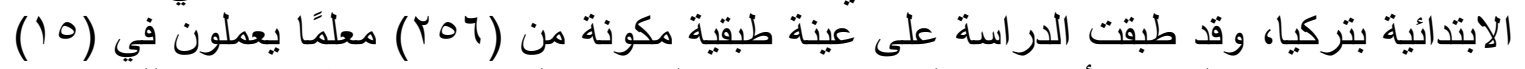

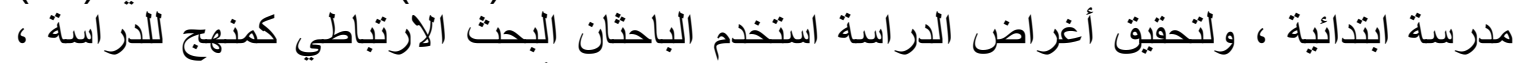

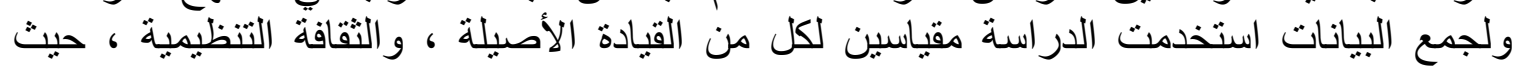

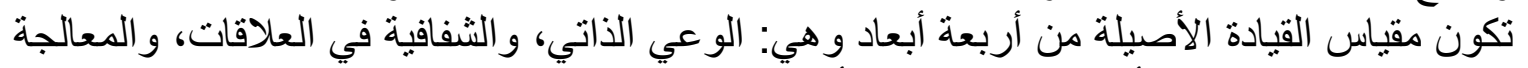

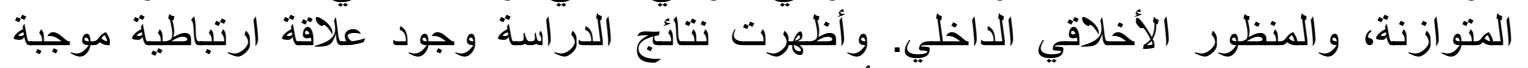

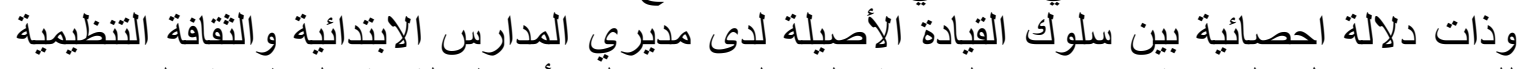

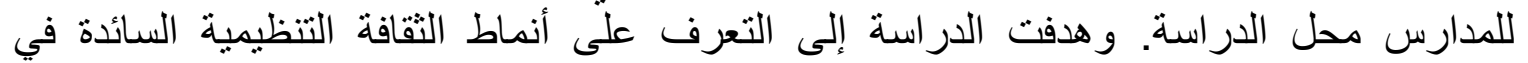

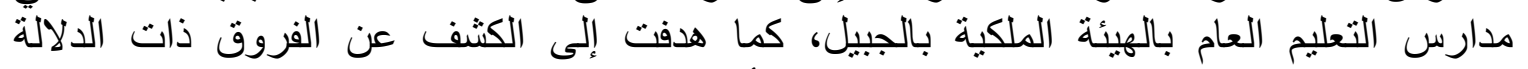

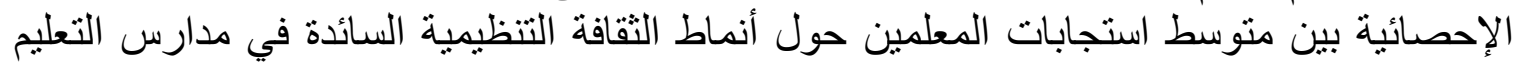

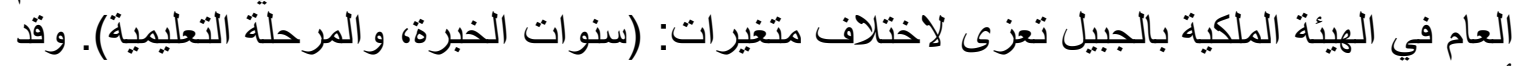

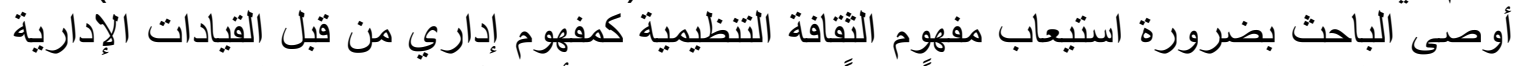

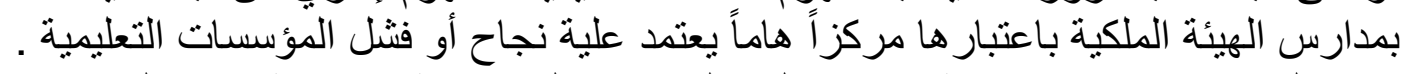

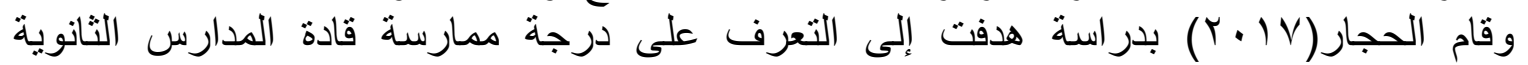

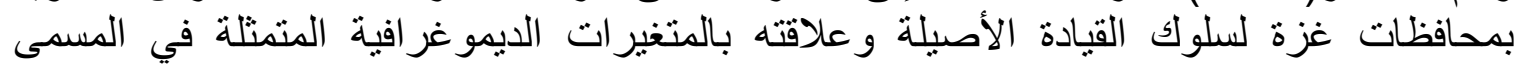

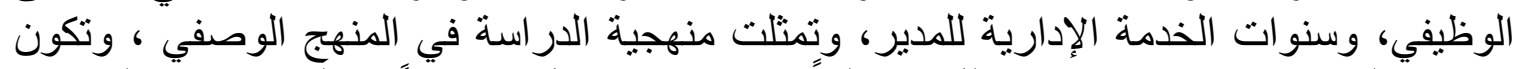

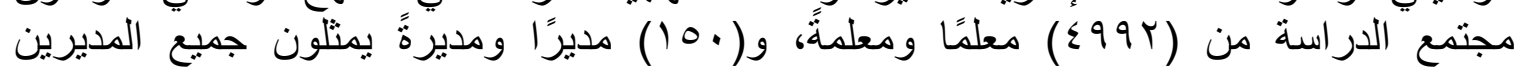

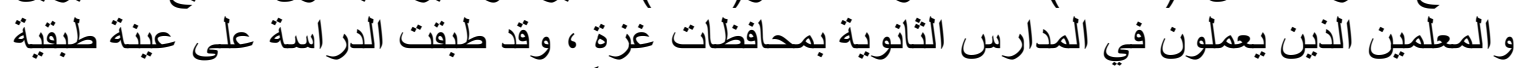

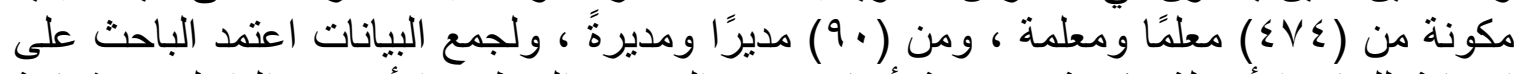

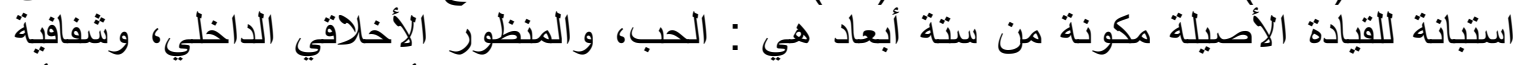

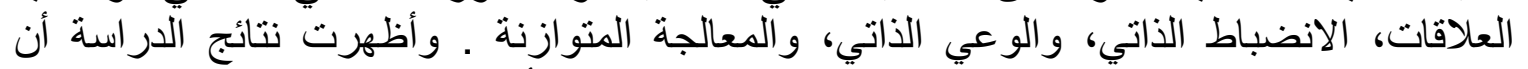

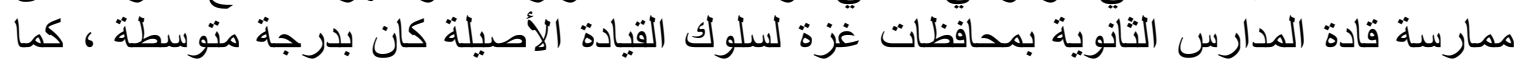

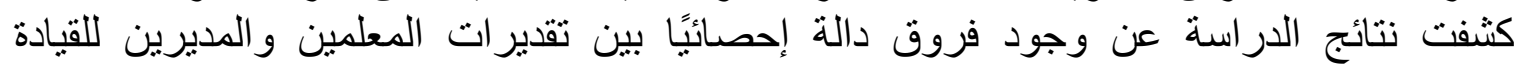

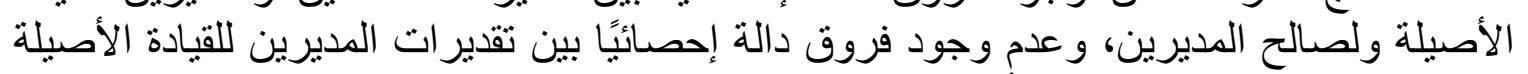

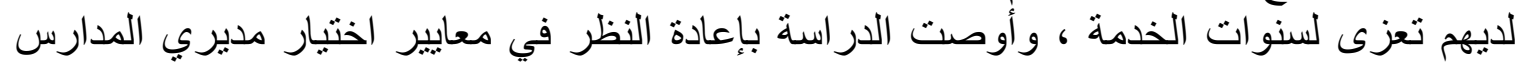

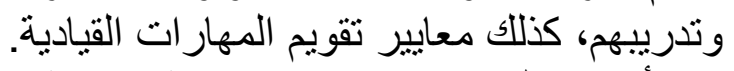

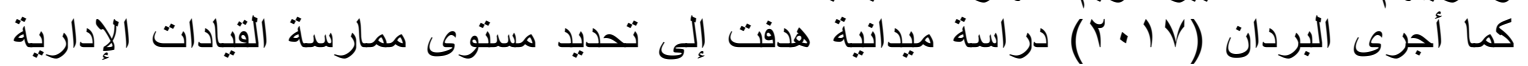

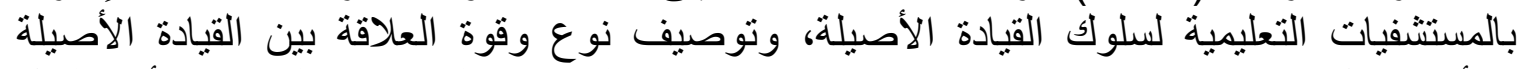

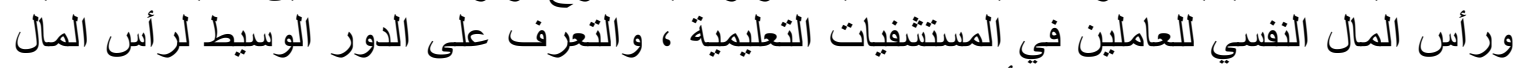

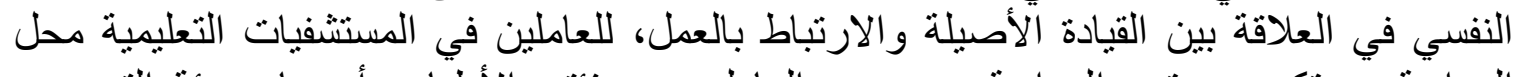

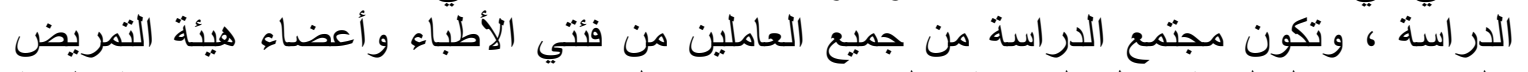

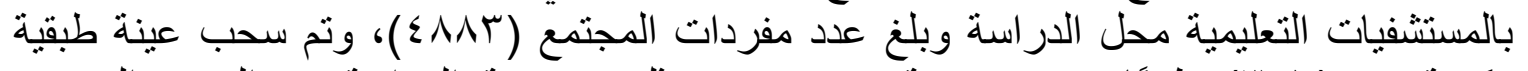

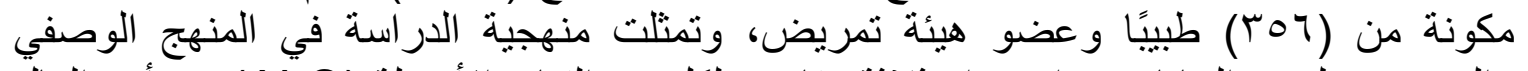

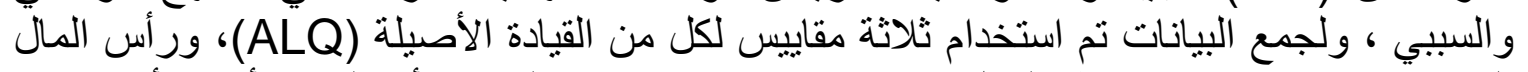
النفسي (PCQ) ، والارتباط بالعمل (WEQ)، وتكون مقياس القيادة الأصيلة من أربعة أبعاد هي: البي: 


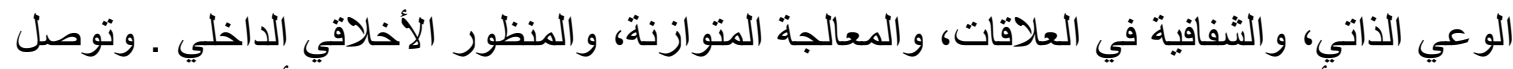

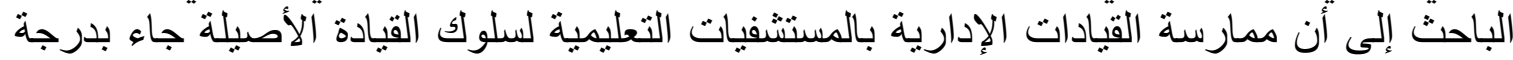

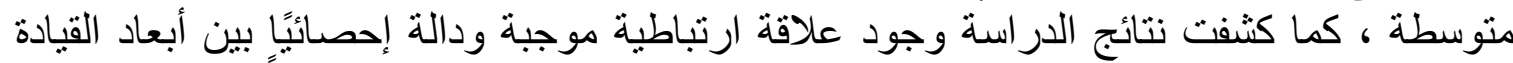

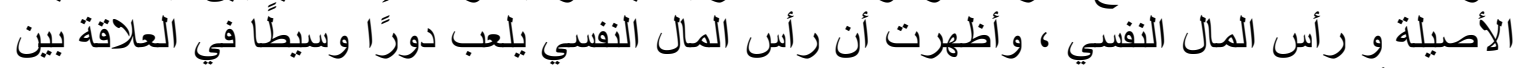

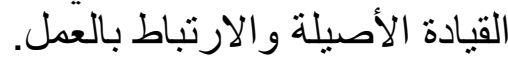

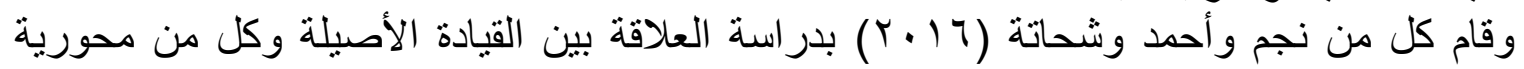

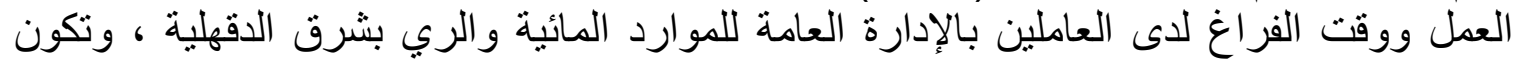

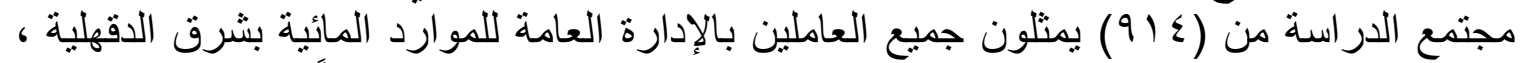

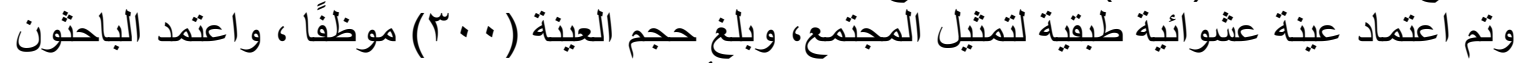

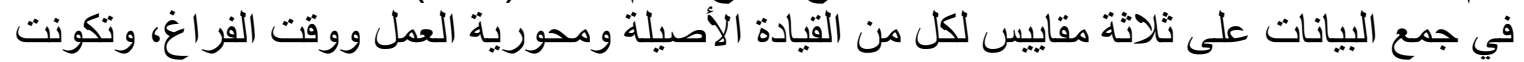

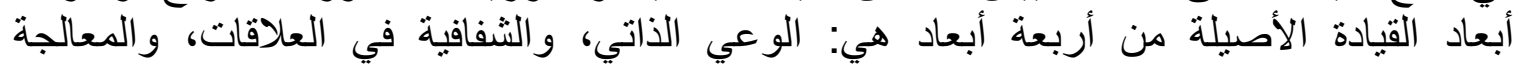

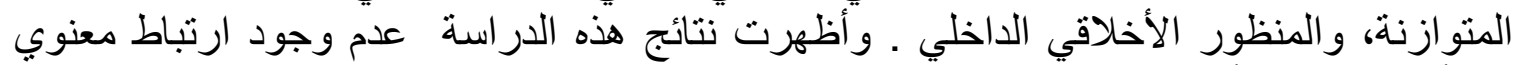

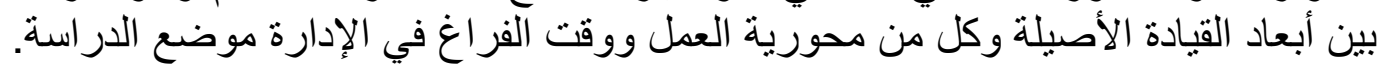

• المحور الثاني: دراسات متعلقة بالصحة التنظيمية: من الدراسات التي تناولت الصحة التنظيمية وذات الصلة بموضوات الصنة الدراسة الحالية في حدود علم

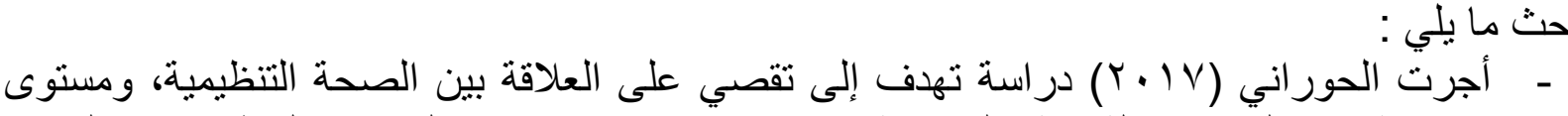

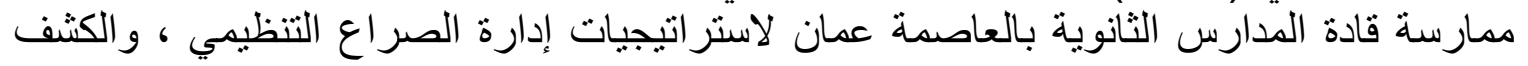

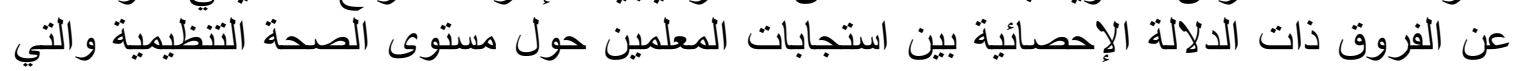

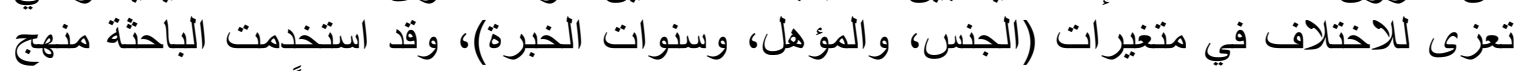

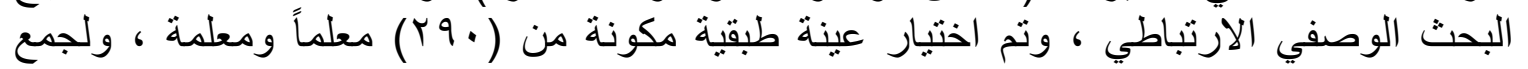

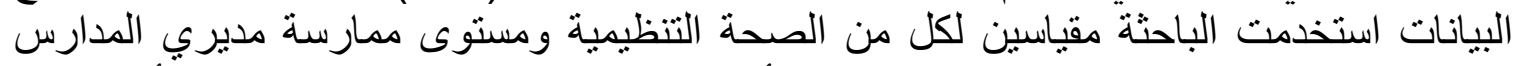

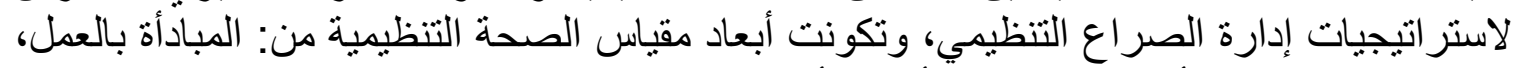

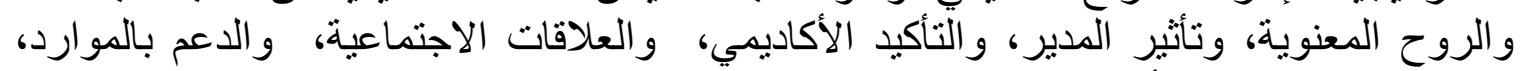

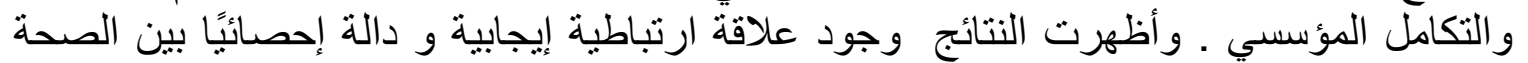

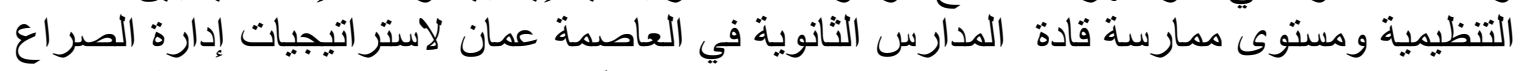

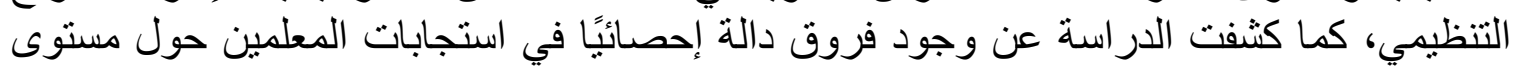

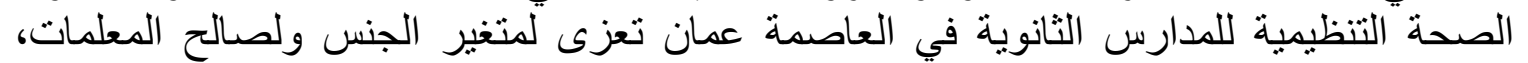

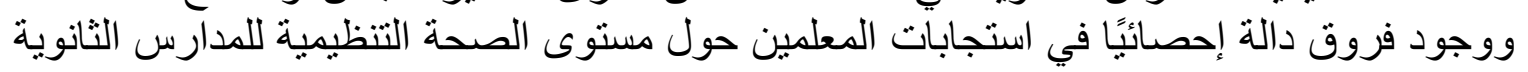

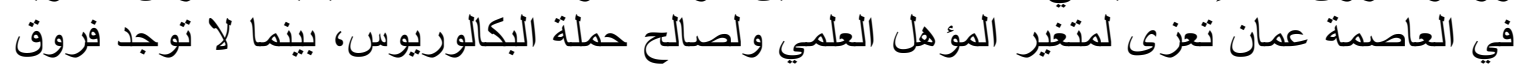

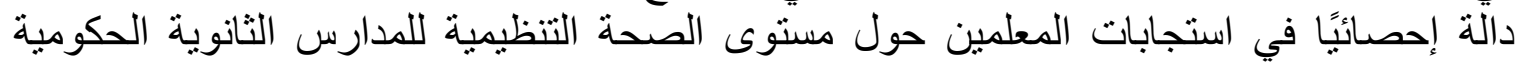

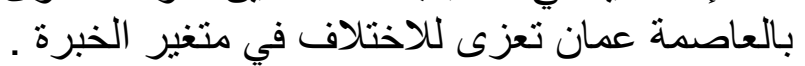

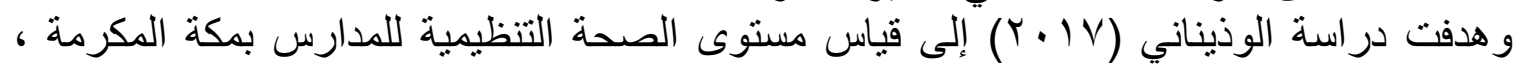

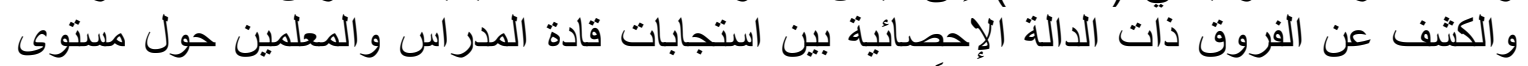

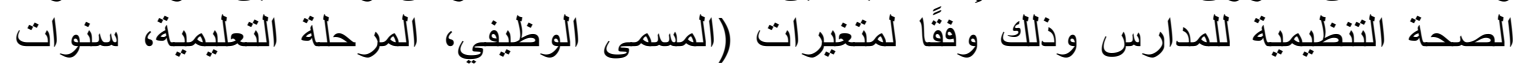

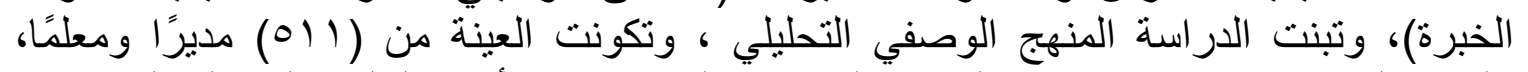

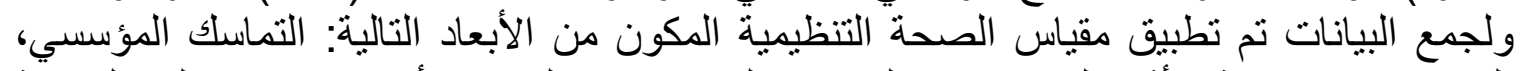

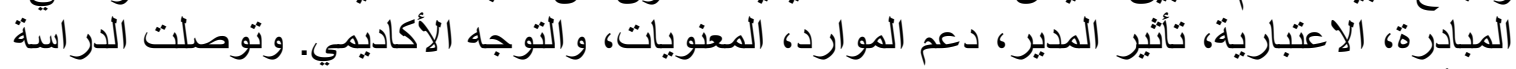

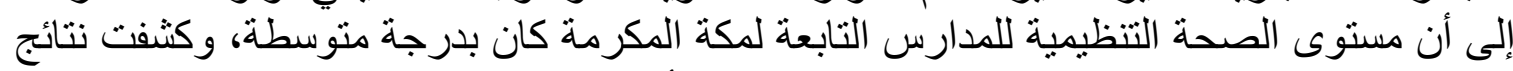

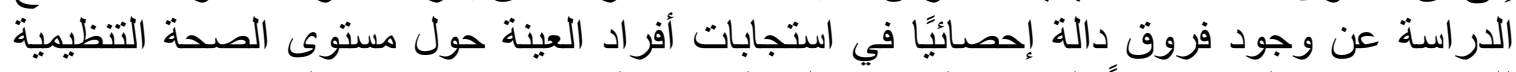

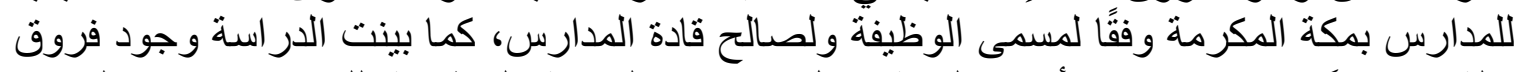

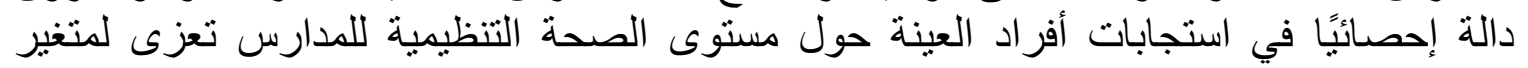


المرحلة التعليمية ولصالح المرحلة الابتدائية، بينما لا توجد فروق دالة إحصائًًا في استجابات أفراد

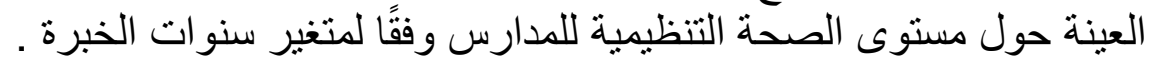

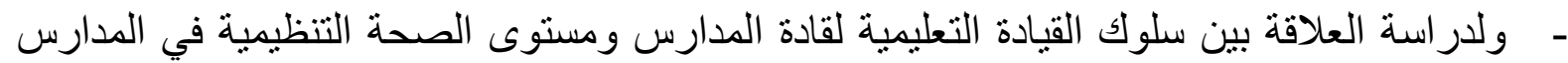

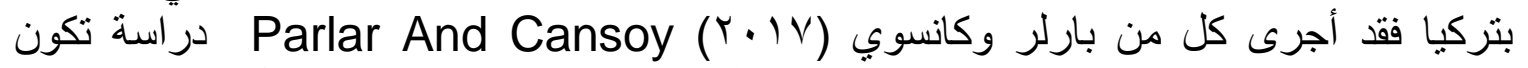

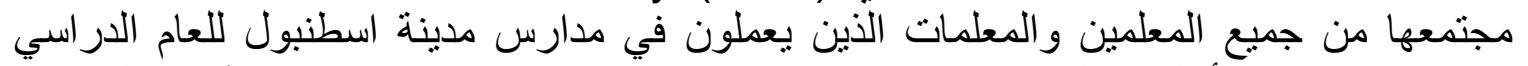

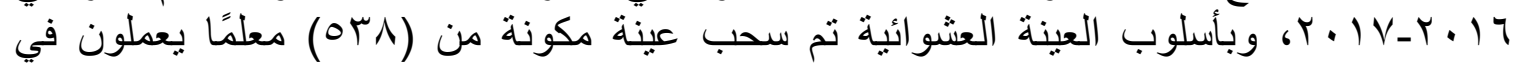

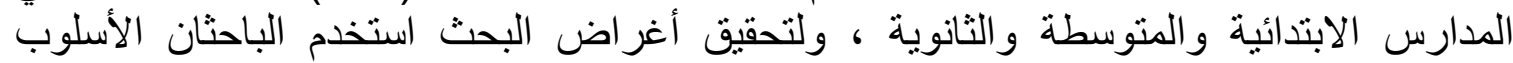

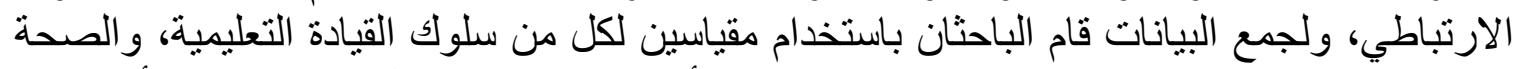

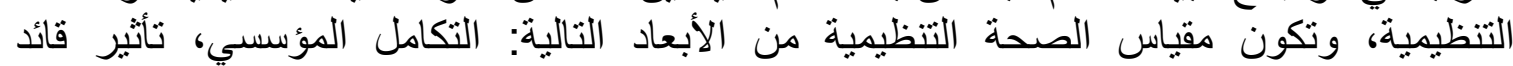

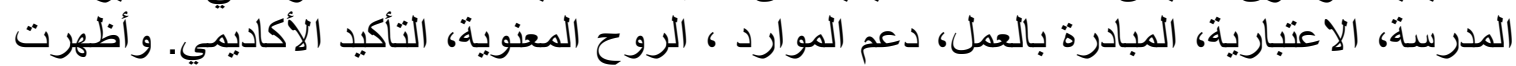

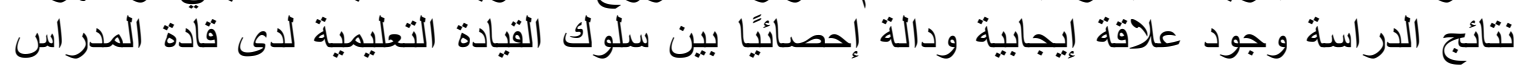
ومستوى الصحة التنظيمية لمدارسهر.

التعليق على الدراسات السابقة المتعلقة بمتغيرات الاراسة الحالية:

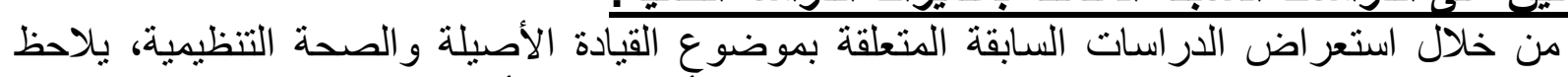

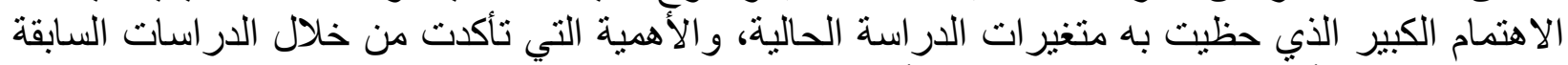

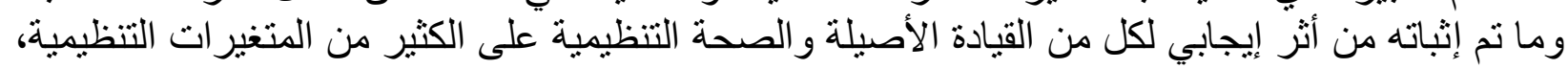

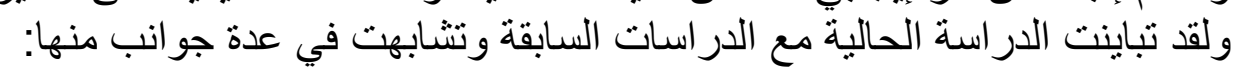

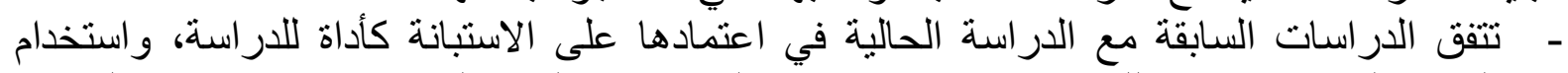

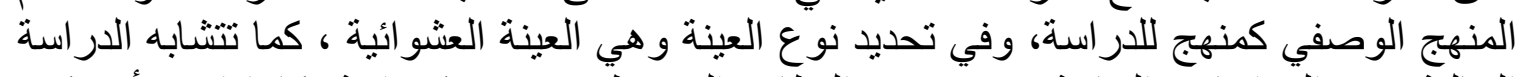

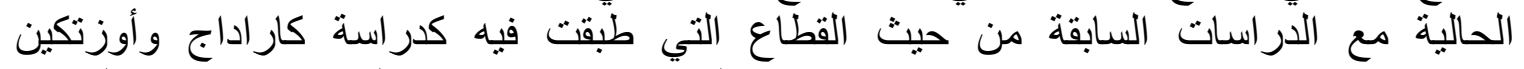
Karadag And Oztekin(Y./1) (Y • l V)

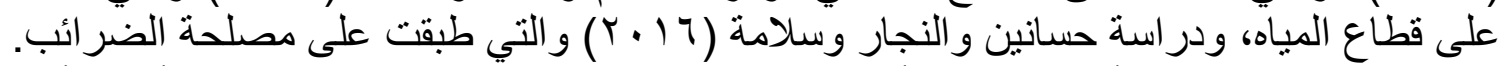

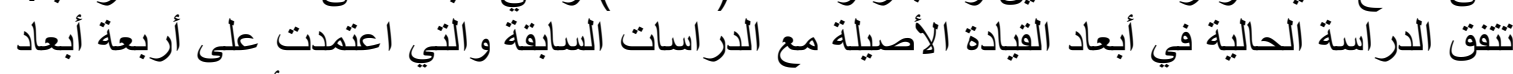

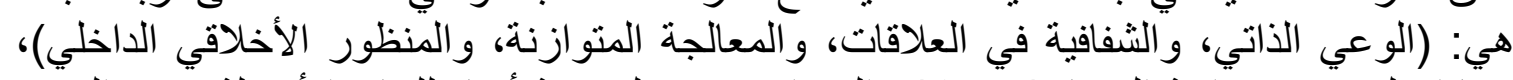

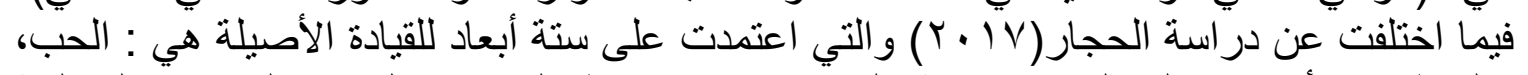

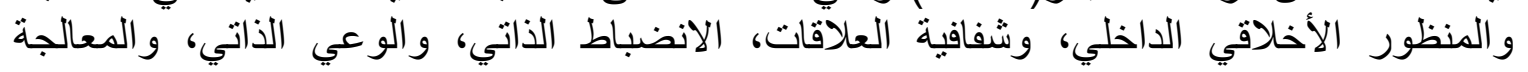

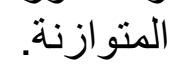
تتفق الدراسات السابقة المتعلقة بالصحة التنظيمية مع الدراسة الحالية في اعتمادها على الاستبانة

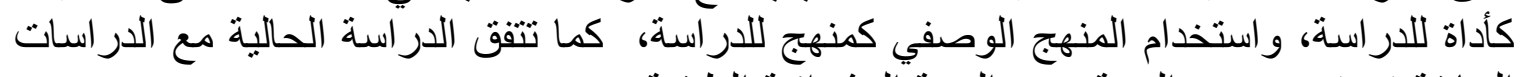

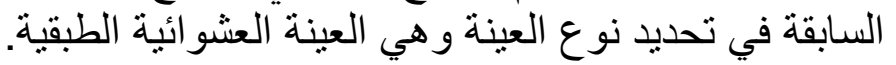

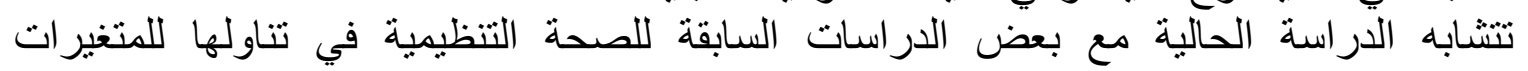

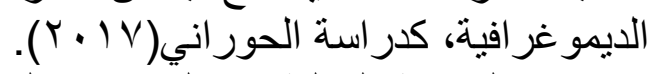

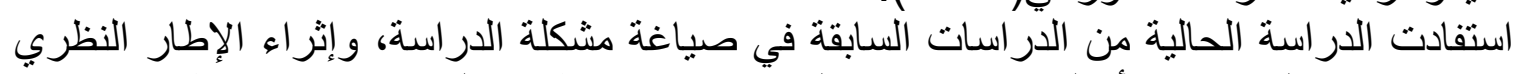

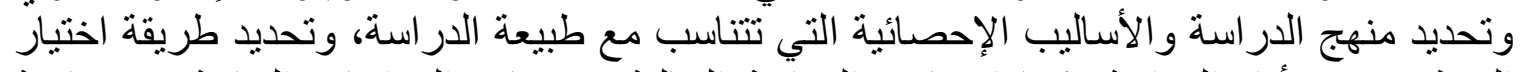

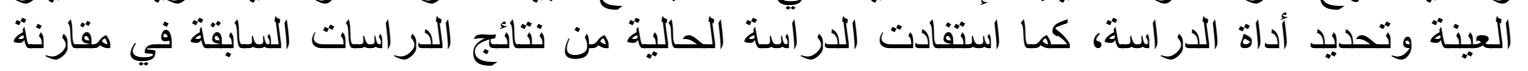

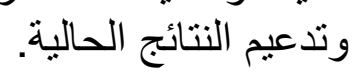




\section{ثالثًا : طريقة وإجراءات الاراسة:}

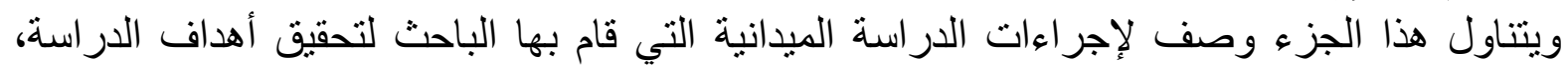
وتحديد منهجها، ومجتمعها، و عينتها، وأداتها، و المعالجة الإحصائية المستخدمة في تحليل النتائج. ( ) منهج الاراسة:

تحقيقًا لأهداف الدراسة استخدم الباحث الدنهج الوصفي بأسلوبيه المسحي والارتباطي، لكونه أكثر

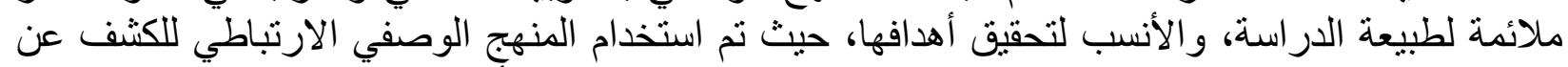

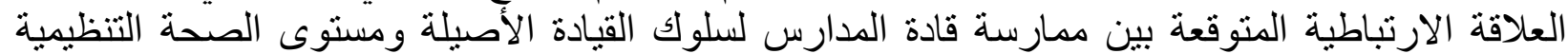

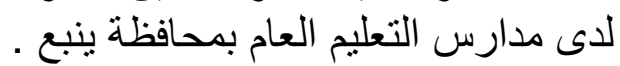

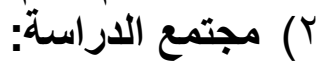
تكون مجتمع الدراسة الحالي من جميع المعلمين الذين يعملون في مدارس التعليم العام الحكومية

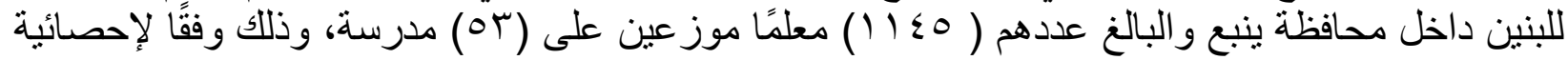

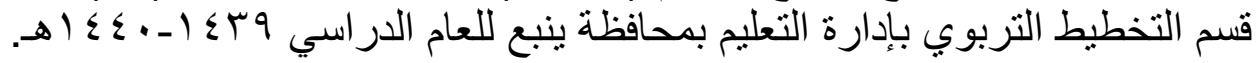
ويوضح الجدول( (1) توزيع معلمي مدارس التعليم العام الحكومية للبنين داخل محافظة ينبع وفقًا للمرحلة

جدول (1)

توزيع أفر اد مجتمع الدراسة وفقاً للمرحلة التعليمية

\begin{tabular}{|c|c|c|c|}
\hline النسبة \% & عدد المعلمين & المرحلة الدراسية & 5 \\
\hline$\%$ or.r & 099 & المرحلة الابتدائية & 1 \\
\hline \%YY. & rqA & المرحلة المتوسطة & r \\
\hline$\%$ \%I.V & $r \leqslant \Lambda$ & المرحلة الثانوية & $r$ \\
\hline$\% 1 \ldots$ & $11 \leqslant 0$ & المجموع & \\
\hline
\end{tabular}

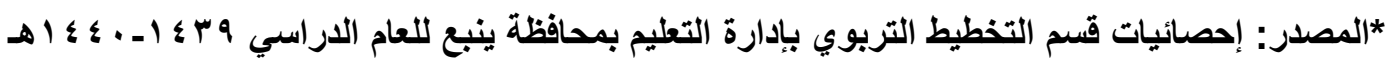

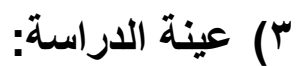
تم اختيار عينة الدر اسة بطريقة العينة العشوائية الطبقية، حيث قام الباحث بتوزيع الاستبانة الكترونباً

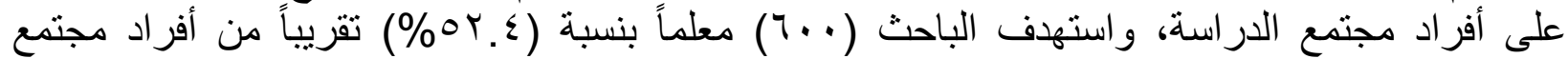

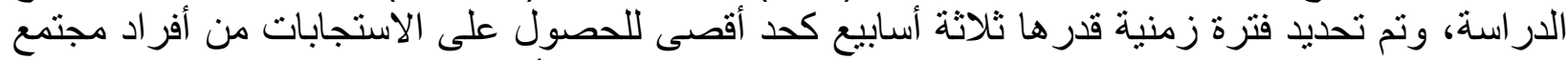

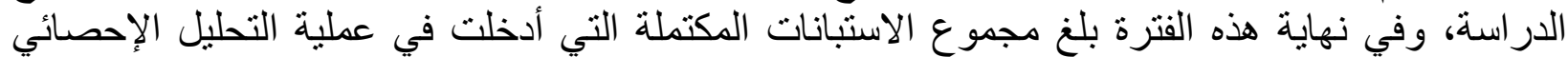

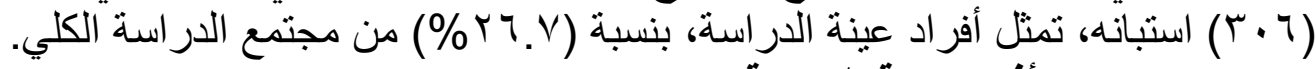
خصائص أفراد عينة الدراسة :

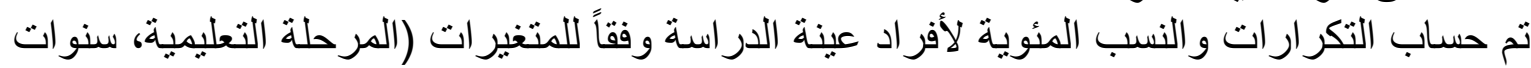

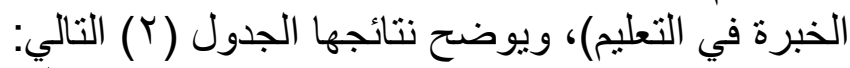

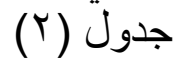

التكرار ات و النسب المئوية لأفر اد عينة الدر اسة موز عين وفقاً للمتغير ات الثخصية

\begin{tabular}{|c|c|c|c|c|}
\hline النسبة\%\% & التكرار & المستوى & المتغير & م \\
\hline$\% 01.7$ & 101 & الابتدائية & \multirow{3}{*}{ التعليمية } & \multirow{3}{*}{1} \\
\hline$\%$ \% . . & $\Delta r$ & المتوسطة & & \\
\hline$\%$ \% 1.7 & 79 & الثانوية & & \\
\hline$\%$ \%r.V & $1 \cdot r$ & أقلّ من · ا سنوات & \multirow{3}{*}{ فئوات التبليرة } & \multirow{3}{*}{$r$} \\
\hline$\%{ }^{0}$ & 104 & من · ا إلى أقل من · r سنة & & \\
\hline$\% 17 . r$ & 0 . & 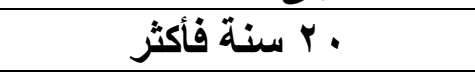 & & \\
\hline$\% 1 \ldots$ & $r \cdot 4$ & \multicolumn{3}{|c|}{ المجموع الكلي } \\
\hline
\end{tabular}




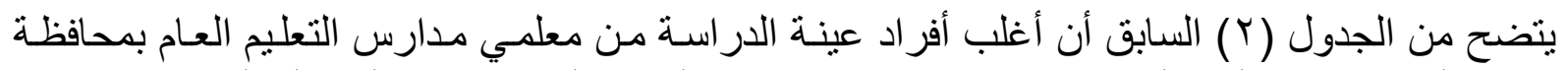

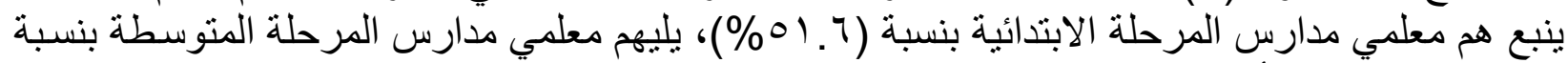

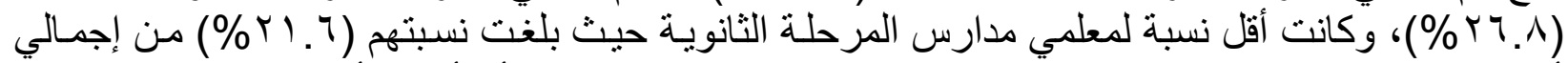

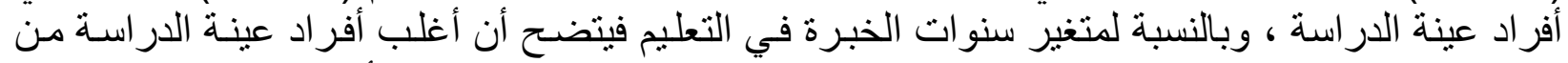

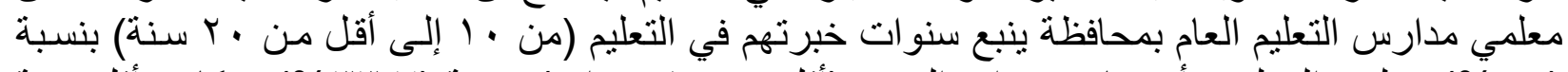

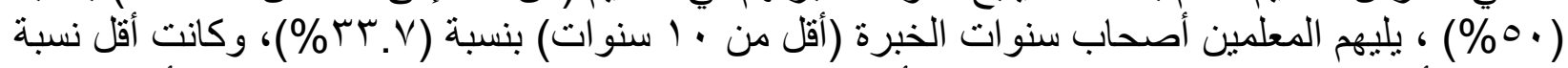

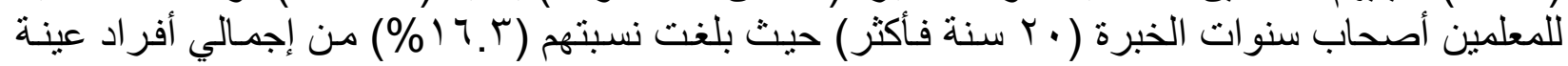

\section{ع) أداة الاراسة (الاستبانة):}

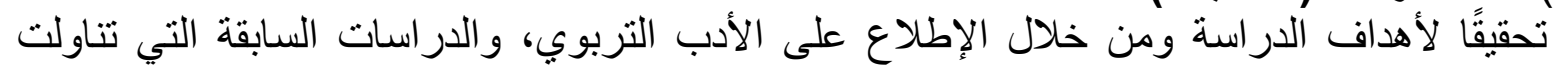

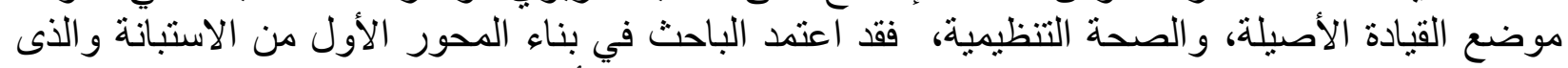

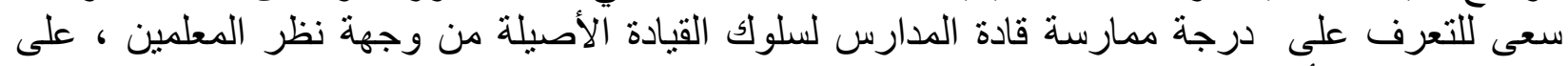

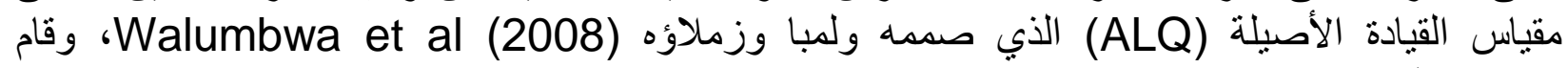

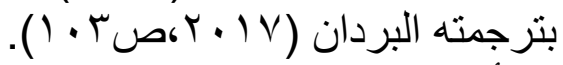
أما فيما يخص البردان (لمحور الثاني والذى هدف إلى التعرف على مستوى الصحة التنظيمية لدى المدارس ،

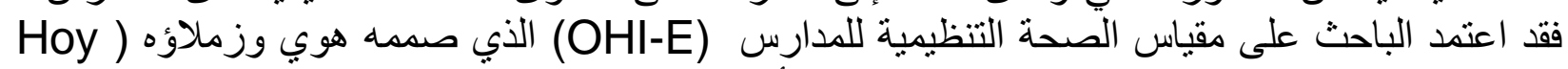

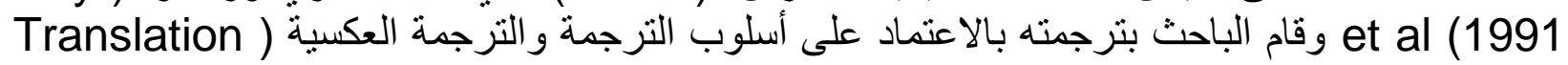

.(and Back Translation

ولقد احتوت الاستبانة في صورتها النهائية على جز أين رئيسيين هما :

الجزء الأول :عبارة عن البيانات الشخصية لأفراد عينة الدراسنة ونئة وتمثلت في في (المرحلة التعليمية، سنو ات الخبرة في التعليم). الجزء الثاني : محاور الاستبانة، وتكون التكون من محورين رئيسبين هما:

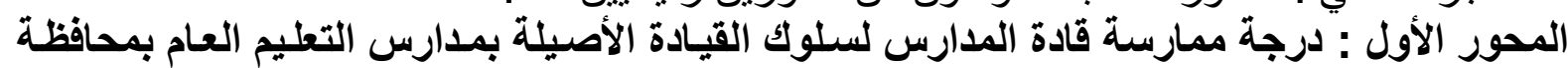

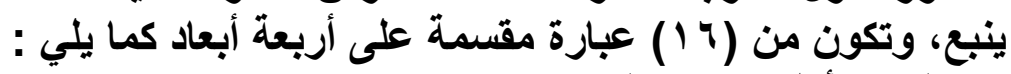

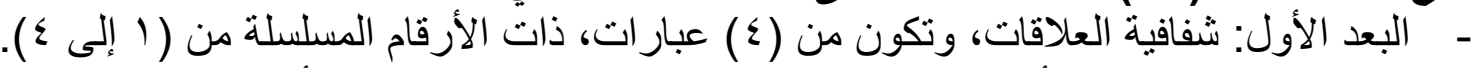

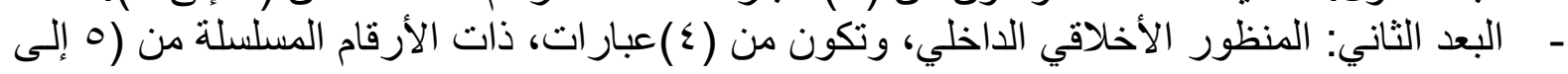

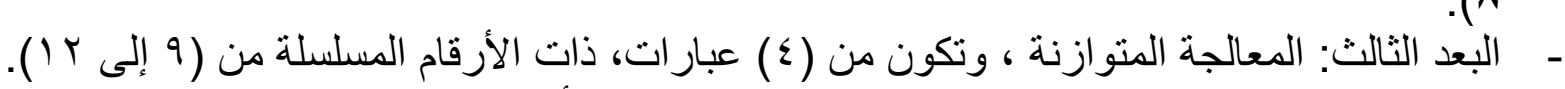

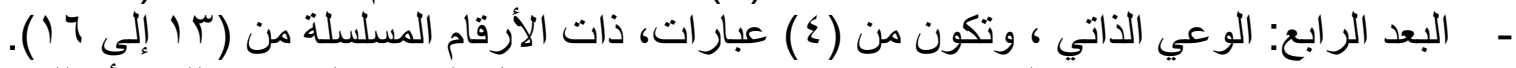

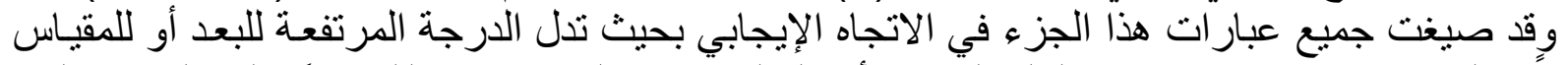

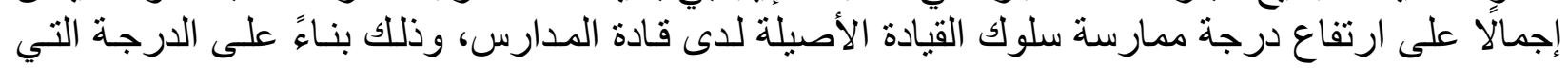

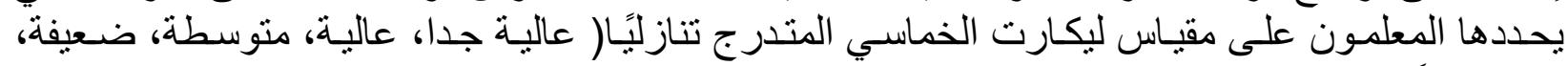

المحور الثاني : مستوى الصحة الصحة التظظيمية لاى مدارس التعليم العام بمحافظة ينبع، وتكون من (rv)

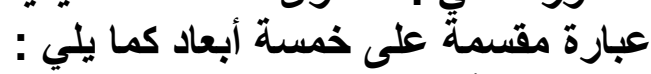

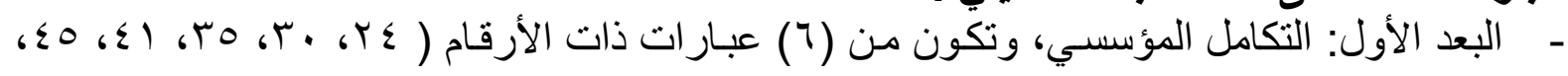

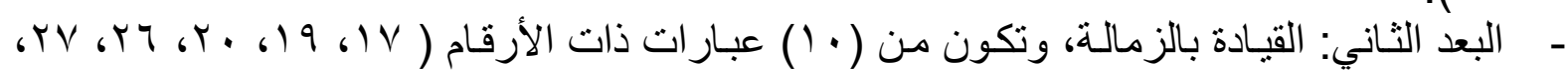

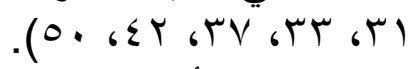

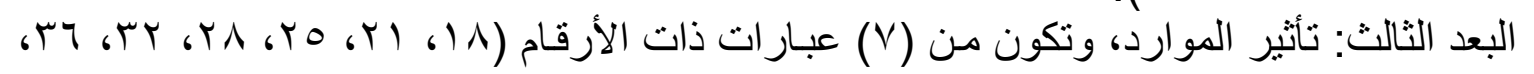
. ( r人

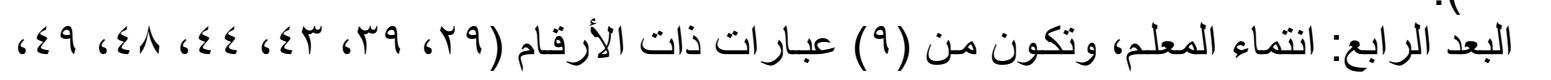
. (or or 60)

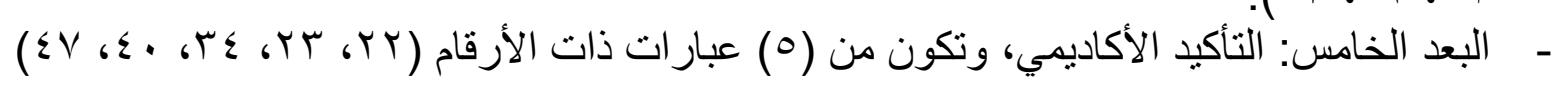


ويوضح الجدول التالي توزيع أرقام عبار ات المحور الثاني من الاستبانة (مستوى الصحة التنظيمية لدى

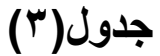

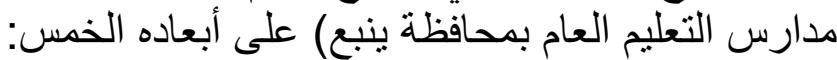

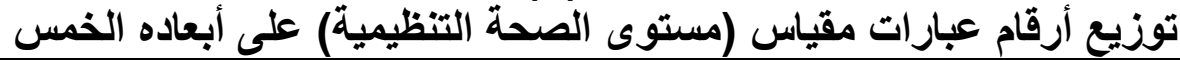

\begin{tabular}{|c|c|c|c|}
\hline عدد العبارات & أرقام العبارات التابعة للبعد في المقياس & الأبعاد & r \\
\hline 7 & 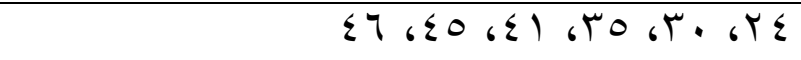 & التكامل المؤسسي & 1 \\
\hline 1 . & 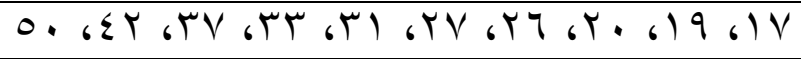 & القيادة بالزمالة & r \\
\hline $\mathrm{V}$ & 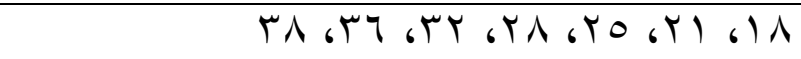 & تثأثير الموارد & $r$ \\
\hline 9 & 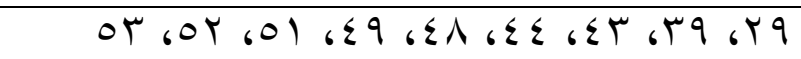 & انتماء المعلم & $\varepsilon$ \\
\hline 0 & $E V_{6} \varepsilon \cdot 6 T E{ }_{6} Y T_{6} Y Y$ & التأكيد الأكاديمي & 0 \\
\hline
\end{tabular}

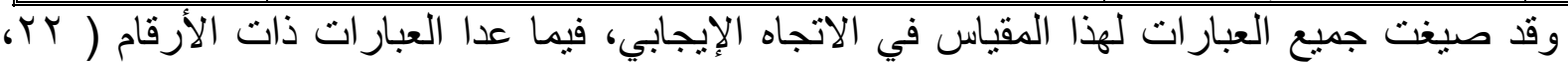

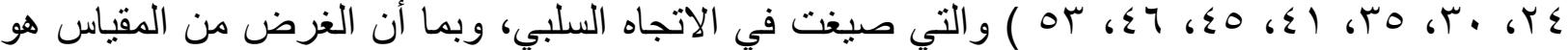

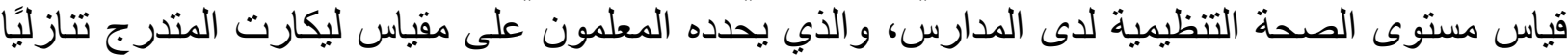

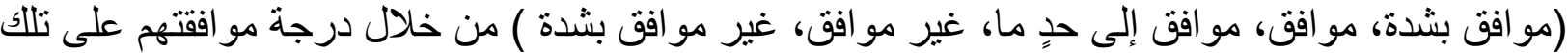
العبارات، لذا يتم عكس الدرجات بالنسبة للعبارات السلبية للحصول على على المتوسط العام لمستوى الصحة

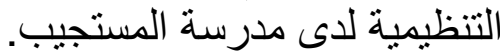

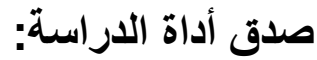

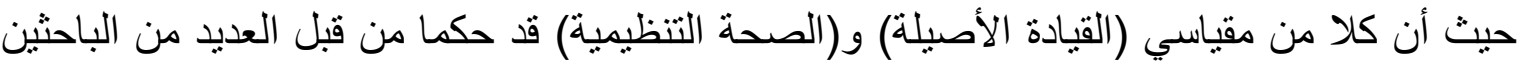

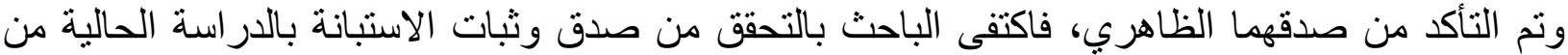

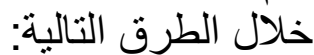
- صدق الاتساق الاخلي للمحور الأول (درجة ممارسة قادة المدارس لسلوك القيادة الأصيلة بمدارس

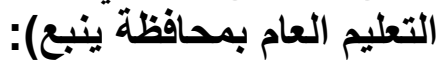
تم حساب صدق الاتساق الداخلي بحساب معامل التهاب التباط بيرسون بين درجات كل عبارة والدرجة

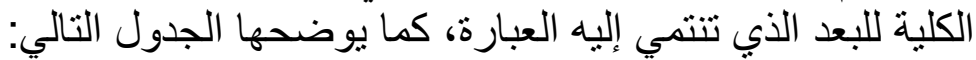

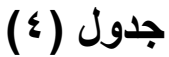

معاملات ارتباط بيرسون بين درجات كل عبارة والدرجة الكلية للبعد الذي تنتمي إليه من المحور الأول

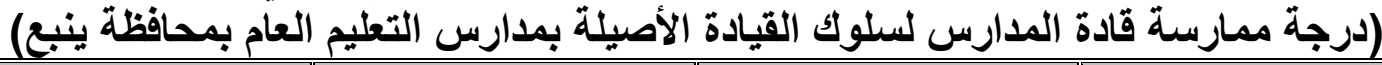

\begin{tabular}{|c|c|c|c|c|c|c|c|}
\hline \multicolumn{2}{|c|}{ البعد الزابع } & \multicolumn{2}{|c|}{ المعالجة المتوازنة } & \multicolumn{2}{|c|}{ المنظور الأبحلاقلاثي الداخلي } & \multicolumn{2}{|c|}{ شففافية العلاقات } \\
\hline معامل الارتباط & P & معامل الارتباط & 5 & معامل الارتباط & p & معامل الارتباط & p \\
\hline **. . 10r & $1 \pi$ & ${ }^{* *} . V V V T$ & 9 & **. . $1 \leqslant$ & 0 & ${ }^{* *} . \wedge 1$. & 1 \\
\hline$* * .101$ & $1 \varepsilon$ & $* * . \wedge 0$. & 1. & ${ }^{* *} . \wedge \uparrow \Lambda$ & 7 & ${ }^{* *} . \wedge \leqslant \wedge \wedge$ & r \\
\hline 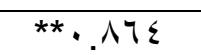 & 10 & $* * . \wedge \mu \wedge$ & 11 & $* * .101$ & v & $* * . . \wedge \vee q$ & $r$ \\
\hline **. . & 17 & **..10\% & IT & ${ }^{* *} . \wedge / r$ & $\Lambda$ & $* * .101$ & $\varepsilon$ \\
\hline
\end{tabular}

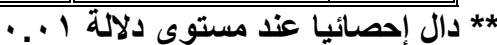

يتبين من الجدول (ع) الابابق أن معاملات ارتباط العبارات بالدرجة الكلية للبعد الذي تنتمي إليه

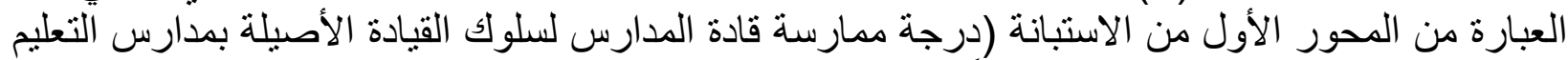

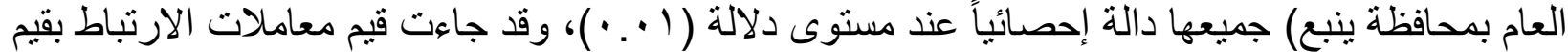

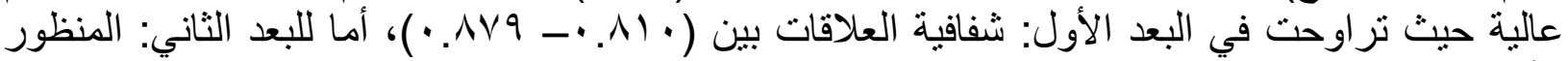

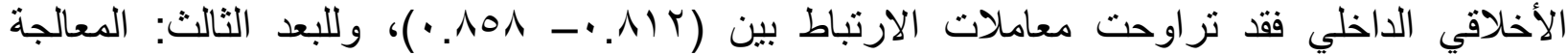

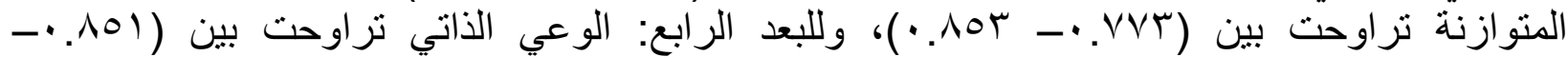

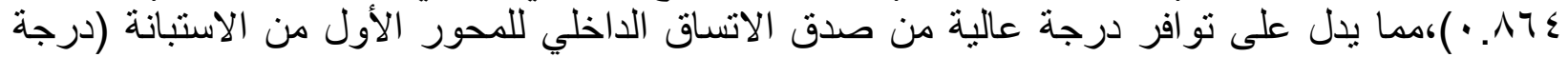
ممارسة قادة الددارس لسلوك القيادة الأصيلة بمدارس التعليم العام بمحافظة ينبع). 
- الصدق البنائي للمحور الأول (درجة ممارسة قادة المدارس لسلوك القيادة الأصيلة بمدارس التعليم

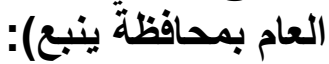

تم التحقق من الصدق البنائي للمحور الأول من خلال إيجاد معاملات الارتباط بين الدرجة الكلية لكل

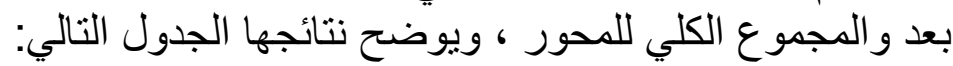

جدول (ن) جدولة

معاملات الارتباط بين درجات كل بعد والدرجة الكلية للمحور الأول (درجة ممارسة قادة المدارس لسلوك المارك

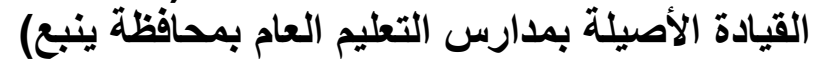

\begin{tabular}{|c|c|c|}
\hline معامل الارتباط & الأبعاد & b \\
\hline$* * .911$ & البعد الأول: شفافية العلاقات & 1 \\
\hline$* * .91 \mathrm{~V}$ & البعد الثاني: المنظور الأخلاقي الداخلي & r \\
\hline$* * .91 \leq$ & البعد الثالث: المعالجة المتوازنة & $r$ \\
\hline$* * .9 \cdot 7$ & البعد الر ابع: الوعي الذاتي & $\varepsilon$ \\
\hline
\end{tabular}

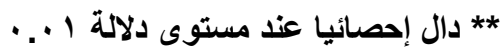

يتبين من جدول (0) السابق أنّ قيم معاملات الارتباط للأبعاد الأربعة التي يتكون منها المحور الأول

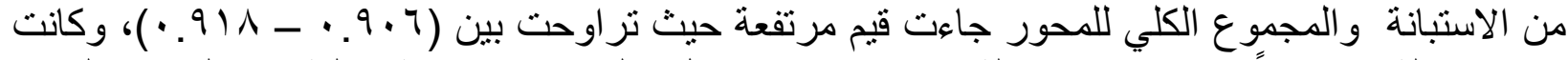

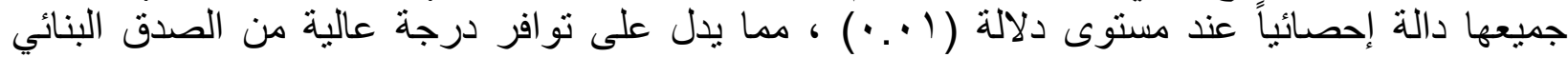
للمحور الأول من الاستبانة (درجة ممارسة قادة المدارس لسلوك القيادة الأصيلة بمدارس التهائة التعليم العام

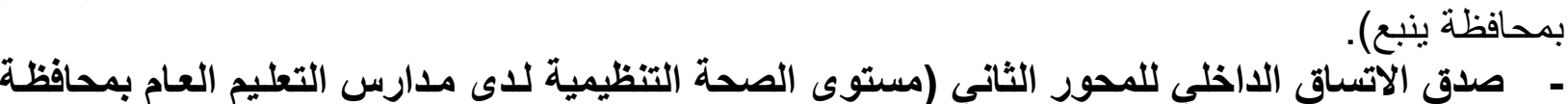
ينبع) : : تم حساب صدق الاتساق الداخلي بحساب معامل ارتباط بيرسون بين درجات كل عبارة و الدرجة الكلية

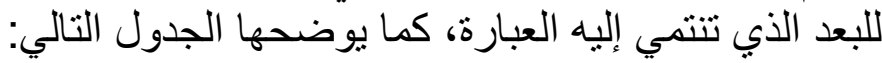

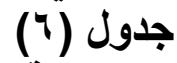

معاملات ارتباط بيرسون بين درجات كل عبارة والدرجة الكلية للبعد الأي تثتمي إليه من المحور الثاني

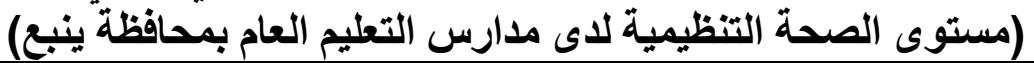

\begin{tabular}{|c|c|c|c|c|c|c|c|c|c|}
\hline \multicolumn{2}{|c|}{ التأكيد الأكاديمي } & \multicolumn{2}{|c|}{ التماء المعلم البع } & \multicolumn{2}{|c|}{ تأثير الموارد الثالث } & \multicolumn{2}{|c|}{ القيادة بالزمألة } & \multicolumn{2}{|c|}{ التكامل المؤسسي الأول } \\
\hline معامل الارتبّاط & P & معامل الارتباط & 5 & معامل الارتباط & 5 & معامل الارتباط & م & معامل الارتباط & 5 \\
\hline$* *, V \wedge I$ & $\overline{Y Y}$ & $\bar{N}^{* *}, \mathrm{V \wedge} V$ & $\overline{r q}$ & $* * .794$ & 11 & ${ }_{* *}^{*} . \wedge 1$. & $1 \mathrm{~V}$ & $\overline{E * * . V \cdot Y}$ & $\overline{Y Y \xi}$ \\
\hline$* * . \vee \vee$. & rr & $* * . \wedge \cdot 1$ & $r q$ & $* * . V 9 V$ & YI & $* * ., V \vee r$ & 19 & **. Or. & $r$. \\
\hline$* *, y \circ V$ & $\Gamma \xi$ & **. . 11. & $\varepsilon r$ & ${ }^{* *} . V \Gamma 4$ & ro & $* *, V \Psi V$ & $r$. & $* * . V V$. & ro \\
\hline$* * . V \Gamma I$ & $\varepsilon$. & $* * . \wedge r V$ & $\varepsilon \varepsilon$ & $* * . \wedge \leqslant \leqslant$ & $r \wedge$ & $* * . \wedge r \leqslant$ & r7 & **. . .77 & § \\
\hline$* * \cdot, \wedge .0$ & $\varepsilon V$ & 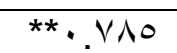 & $\varepsilon \wedge$ & **. .^乏. & rY & **. . AYr & TV & **, V० & $\leqslant 0$ \\
\hline & & $* * . V Y V$ & $\leqslant 9$ & ${ }^{* *}, . \vee V \varepsilon$ & T4 & $* *, . V \leq 9$ & Tा & $* * . V 1$. & $\sum 7$ \\
\hline & & $* * . \wedge T Y$ & 01 & **, VAN & rᄉ & $* * .119$ & r & & \\
\hline & & $* * . \vee \vee \vee q$ & OY & & & $* *, V \vee Y$ & rv & & \\
\hline & & ${ }^{* *} \cdot . V 9 Y$ & or & & & $* *, .7 \wedge 0$ & $\varepsilon Y$ & & \\
\hline & & & & & & 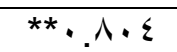 & 0. & & \\
\hline
\end{tabular}

** دال إحصائيا عند مستوى دلالة 1 ... . . .

يتبين من الجدول (T) السابق أن معاملات ارتباط العبارات بالدرجة الكلية للبعد الذي تنتمي إليه العبارة

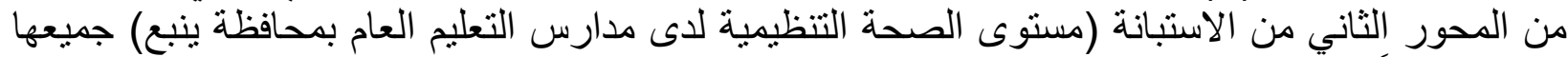

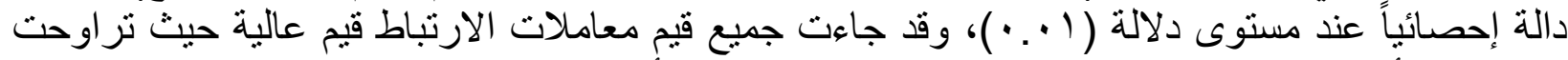

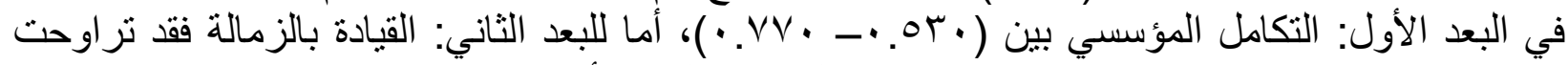

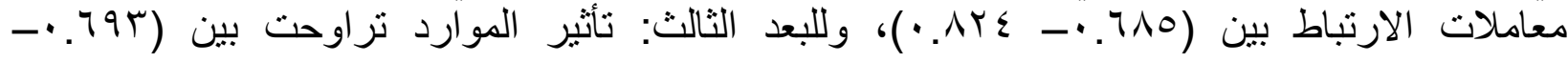




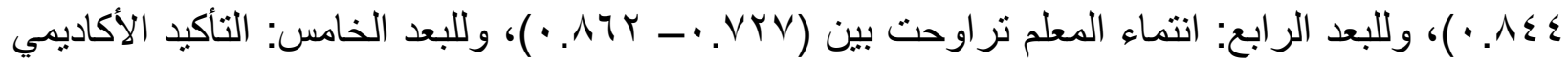

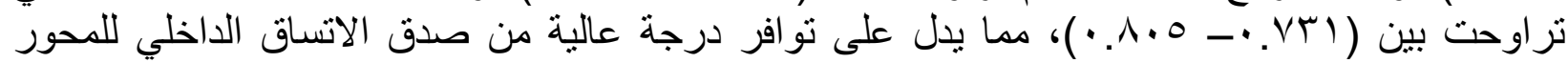

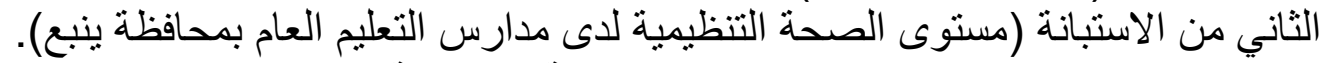

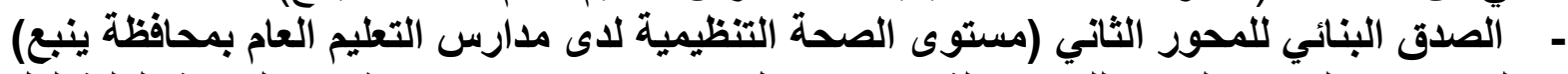

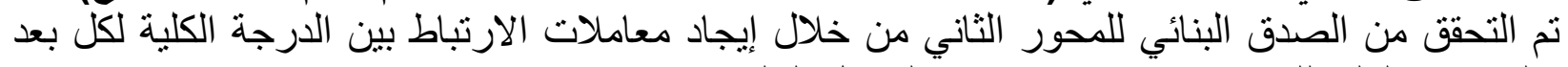

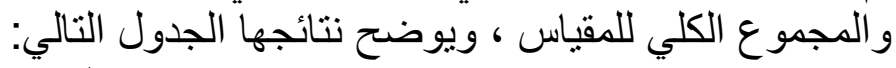
(V) جدول

معاملات الارتباط بين درجات كل بعد والدرجة الكلية للمحور الثاني (مستوى الصحة التظيمية لاى التى

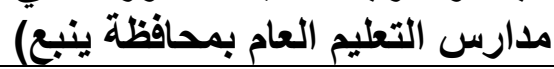

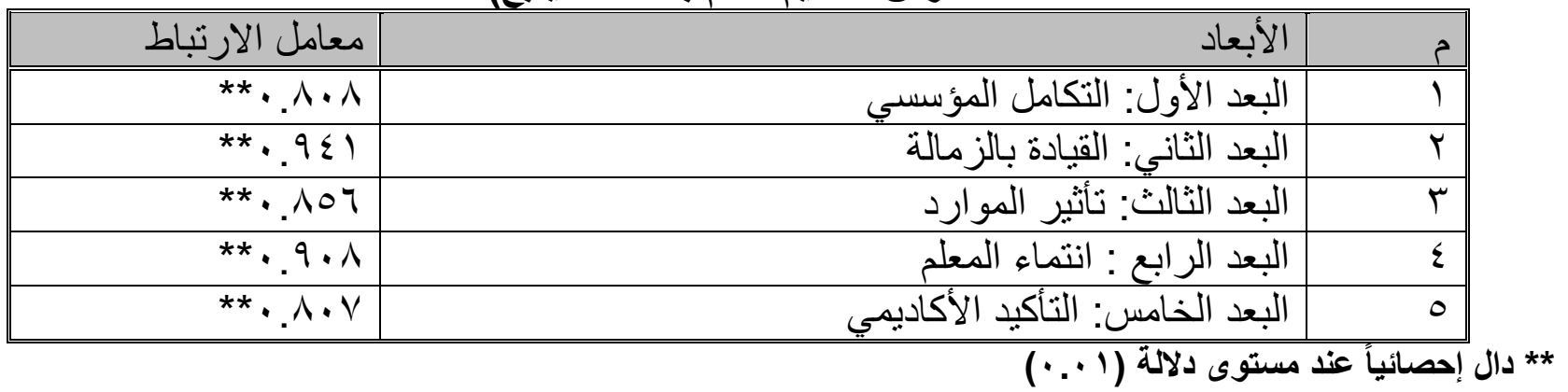

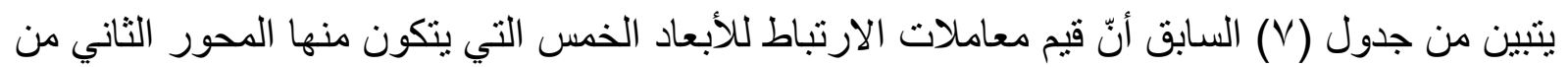

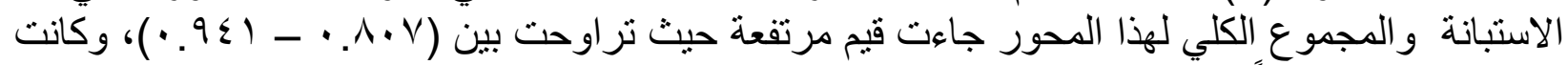

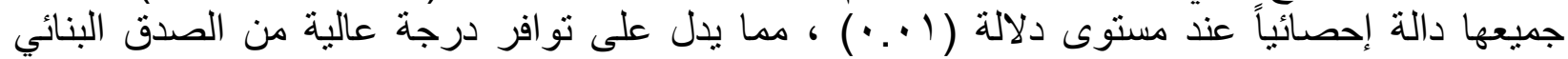
للمحور الثاني من الاستبانة (مستوى الصحة التنظيمية لدى مدارس التعليم العام بمحافظة ينبع).

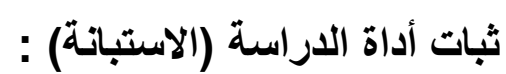

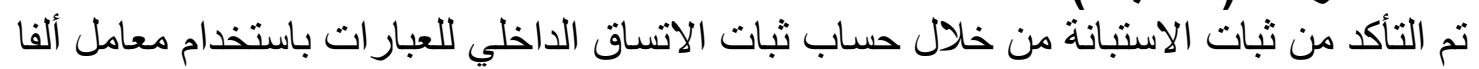

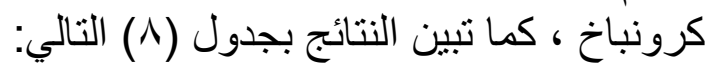

جدول) (^)

عاملات ثبات ألفا كرونباخ للأبعاد ومحوري الاستبانة

\begin{tabular}{|c|c|c|c|}
\hline معامل الثبات & عدد العبار ات & البعد & م \\
\hline.$\wedge V$ & $\varepsilon$ & | البعد الأول: شفافية العلاقات & 1 \\
\hline .10 & $\varepsilon$ & البعد الثاني: المنظور الأخلاقي الداخلي & $r$ \\
\hline .10 & $\varepsilon$ & | البعد الثالث: المعالجة المتوازنة & $r$ \\
\hline$\cdot . \wedge \wedge$ & $\varepsilon$ & | البعد الر ابع: الوعي الذاتي & $\varepsilon$ \\
\hline .90 & 17 & \multicolumn{2}{|l|}{ بمدارسم التعليم العام بمحافظة ينبع) للمجة ممارسة قادة المدارس لسلوك القيادة الأصيلة } \\
\hline$\because \vee \wedge$ & 7 & | البعد الأول: التكامل المؤسسي & 1 \\
\hline .94 & 1 . & | البعد الثاني: القيادة بالزمالة & $r$ \\
\hline. .19 & $\mathrm{~V}$ & |البعد الثالث: تأثثير الموارد & $r$ \\
\hline $.9 \pi$ & 9 & |البعد الر ابع : انتماء المعلم & $\varepsilon$ \\
\hline.$\wedge \Gamma$ & 0 & | البعد الخامس: التأكيد الأكاديمي & 0 \\
\hline$\cdot .9 \mathrm{~V}$ & rv & التنظيمية لاى مدارس التعليم العام & \\
\hline
\end{tabular}

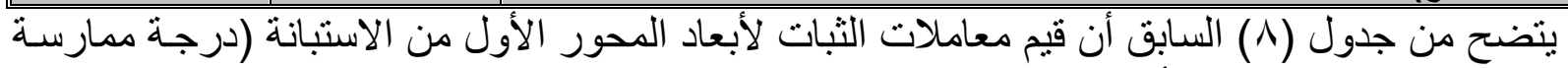

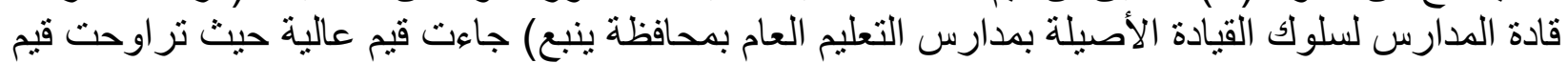

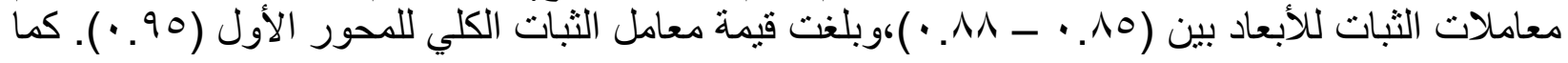


جاءت قيم معاملات الثبات لأبعاد المحور الثاني من الاستبانة (مستوى الصحة التنظيمية لاى مدارس التعليم

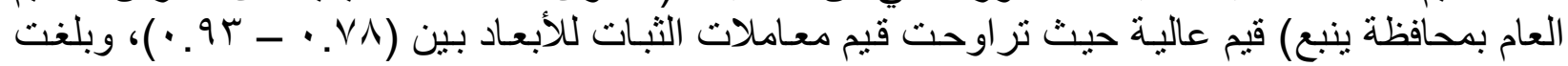

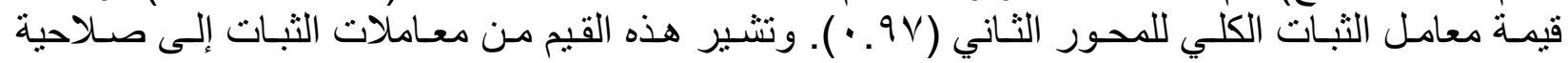

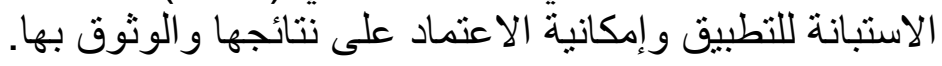

\section{0 أساليب المعالجة الإحصائية:}

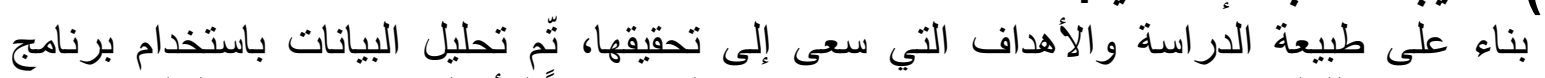
الحزمة الإحصائية للعلوم الاجتماعية (SPSS)، و استخر اج النتائج وفقاً للأساليب الإحصائية لإئية التالية:

ا. التكرارات والنسب المئوية: للتعرف على خصائص أفراد عينة الدراسة وفقا للبيانات الثخصية. r. المتوسطات الحسابية والانحرافات المعيارية: لحساب متوسطات عبارات الاستبيان وكذلك الدرجات الكلية والدرجات الفرعية للاستبانة بناء على استجابات أفراد عينة الدراسة. ومدى تشتت استجابات

\section{أفراد عينة الدراسة عن منوسطاتها.}

ب. معامل ارتباط بيرسون: لحساب الاتساق الداخلي وكذلك لتحديد العلاقة بين ممارسة قادة المدارس

لسلوك القيادة الأصيلة ومستوى الصحة التتظيمية لدى مدارس التعليم العام بمحافظة ينبع. ع. معامل ألفا كرونباخ: لحساب الثبات لعبارات الاستبانة.

هـ معادلة المدى: وذللك لوصف المتوسط الحسـابي للاستجابات على كل عبـارة وبعد، على النحو

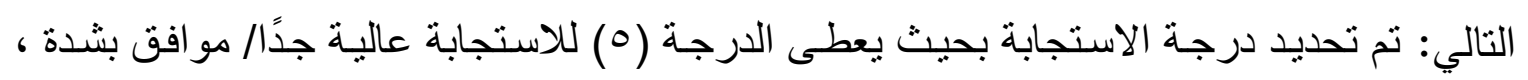

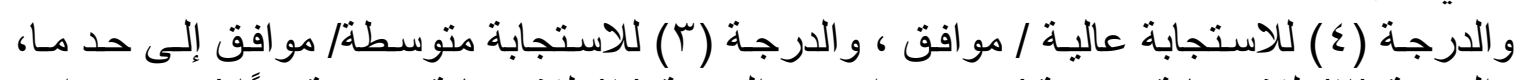

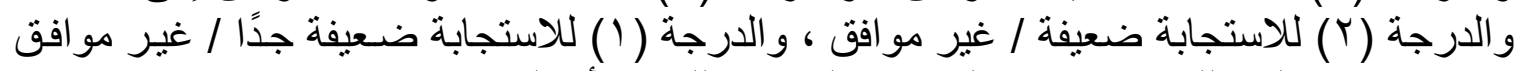

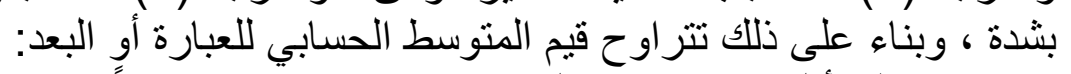

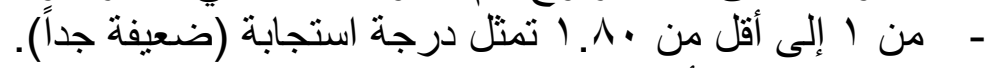

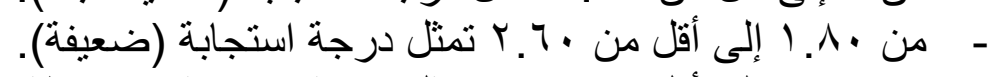

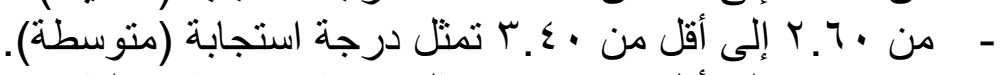

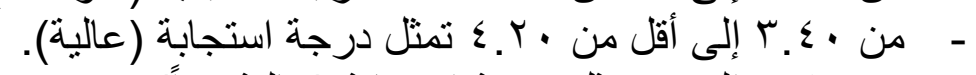

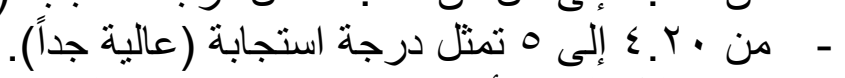

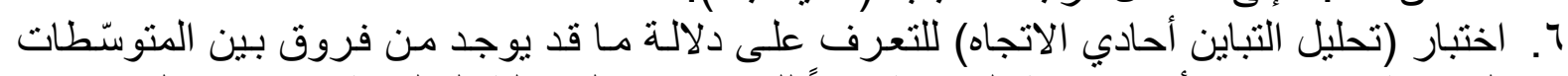

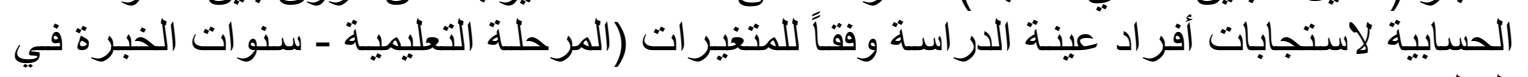
التعليم).

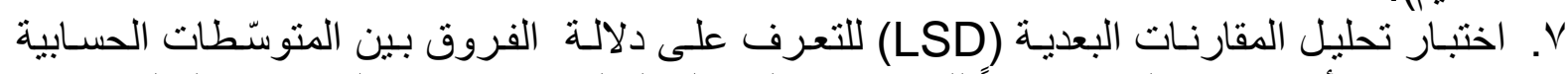

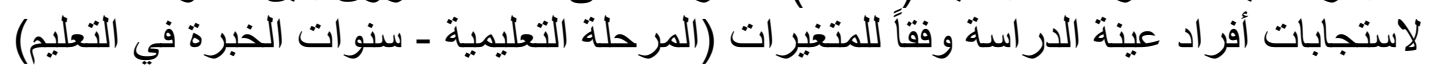

\section{رابعًا : نتائج الاراسة ومناقشتها:}

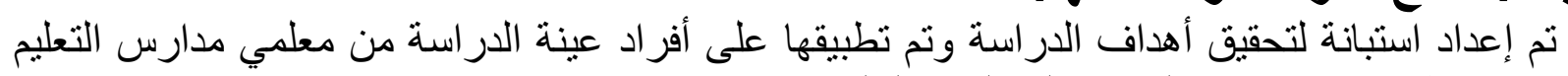

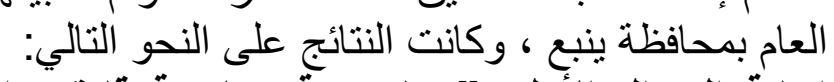

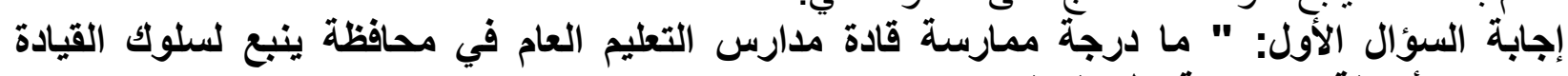

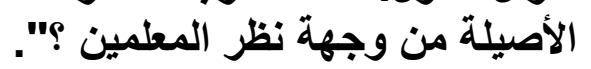

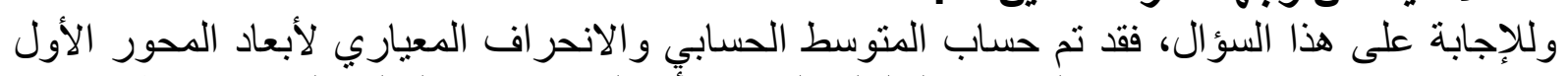

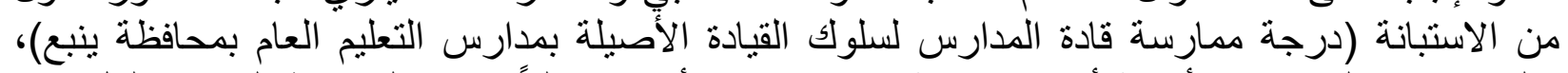

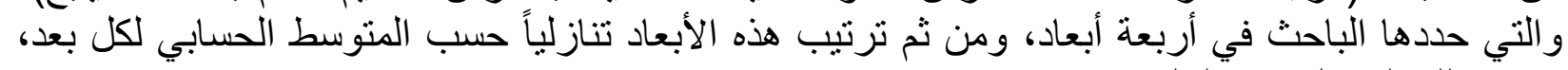
ويبين ذللك الجدول (9) "التالي: 


\section{جدول (9)}

المتوسطات الحسابية والانحر افات المعيارية لأبعاد المحور الأول من الاستبانة (درجة ممارسة قادة الأبة

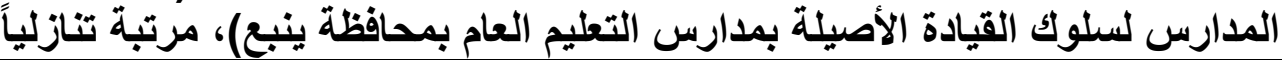

\begin{tabular}{|c|c|c|c|c|c|}
\hline الممارسة & ترتبب البعد & الإنحراف المعياري & المتوسط الحسبي & 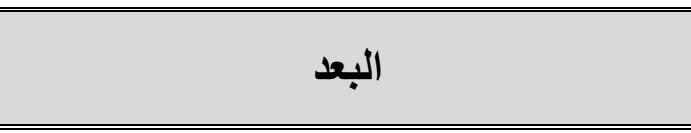 & رقب \\
\hline متوسطة & 1 & $\cdot . \wedge V M$ & $r .7$ & 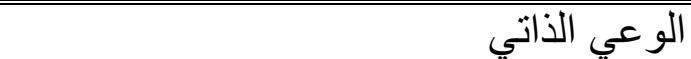 & $\varepsilon$ \\
\hline متوسطة & $r$ &.$\wedge \vee 0$ & $r . r$ & المنظور الأخلاقي الداخلي & r \\
\hline متوسطة & r & $.9 Y r$ & $r . r$ & شفافية العلاقات & 1 \\
\hline متوسطة & $\varepsilon$ & $\cdot \wedge \wedge \wedge$ & $r .90$ & المعالجة المتوازنة & $r$ \\
\hline متوسطة & --- & $\cdot . \wedge 1 \%$ & $r . r$ & لأصيلة بمدارس التعلي (درجة ممارسة قادة المدارس لسلوة بمحافظة بنبع) & القياد \\
\hline
\end{tabular}

يتبين منٍ جدول (9) السابق أن درجة ممارسة قادة مدارس التعليم العام بمحافظة ينبع لسلوك القيادة

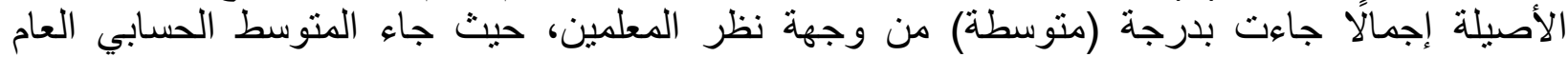

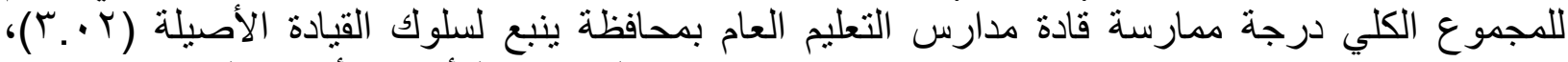

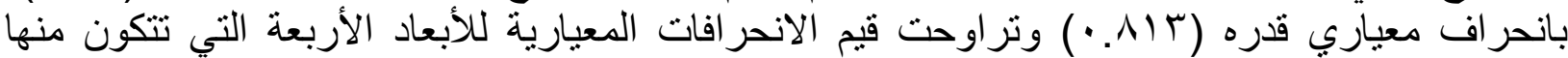

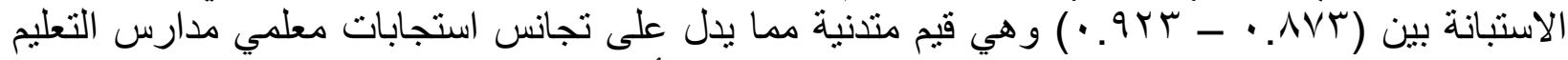

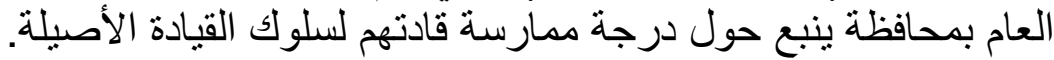

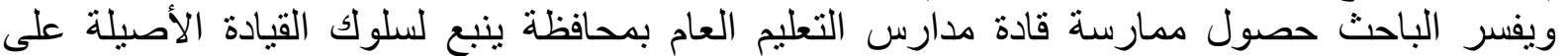

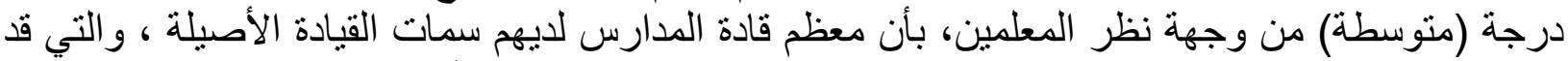
تعود إلى خصوصية البيئة العربية والإسلامية وما تتسم به من قيم ومبادئ أصيلة تؤثر في تكوين شخصية فئية

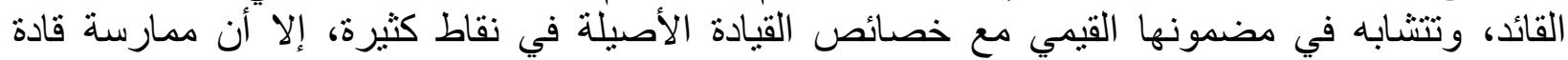
المدارس لسلوك القيادة الأصيلة لم يصل بعد للمستوى المأمول، و قد يعزى ذلك ذلك إلى التباين في الكفايات

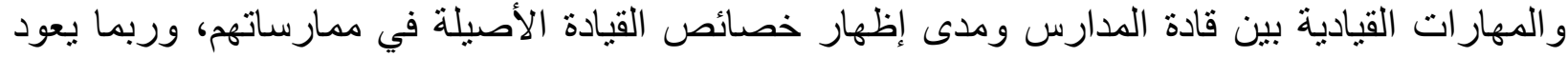

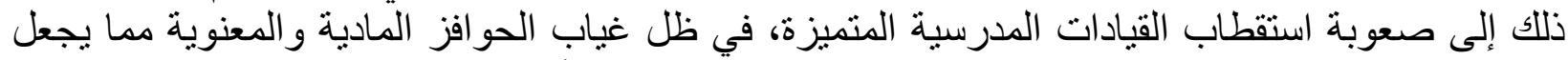

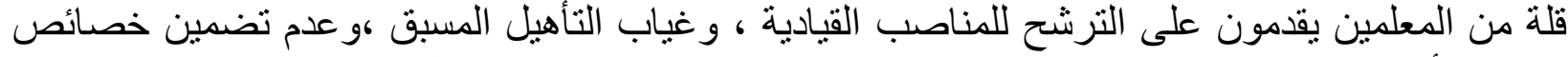

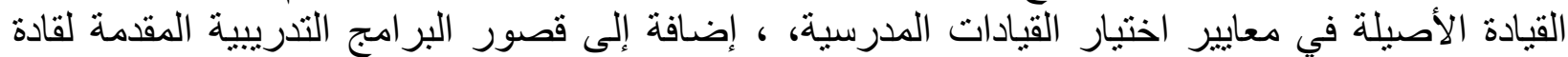

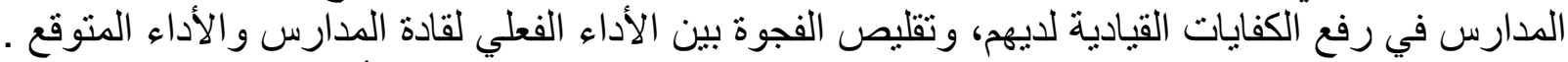

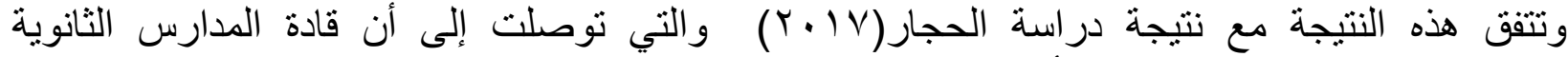

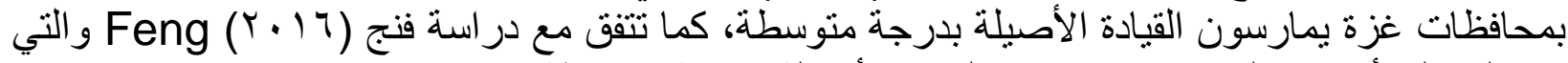

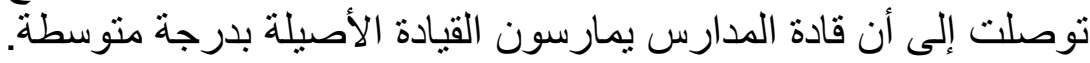

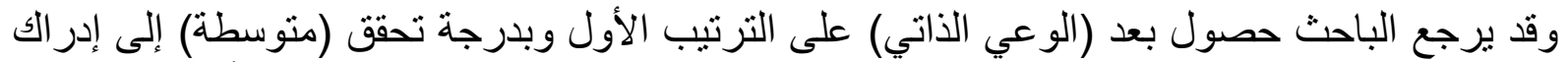

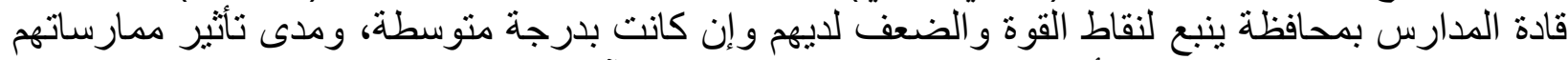

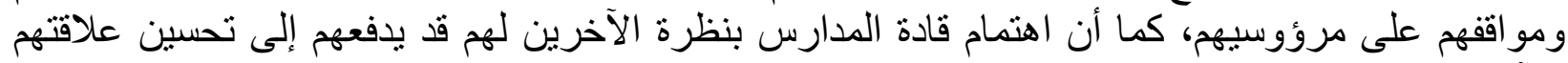

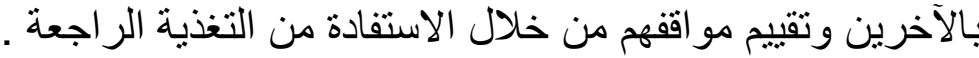

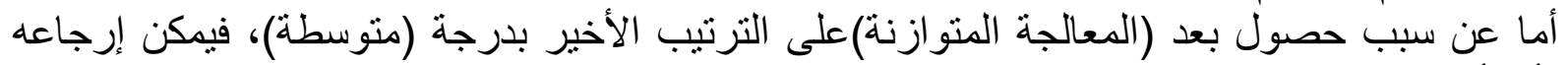

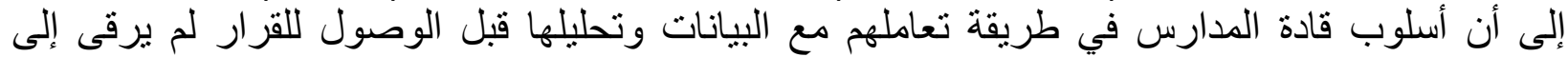

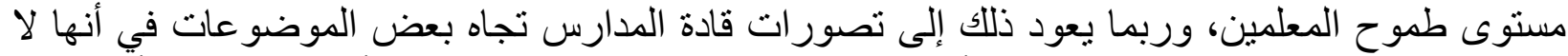

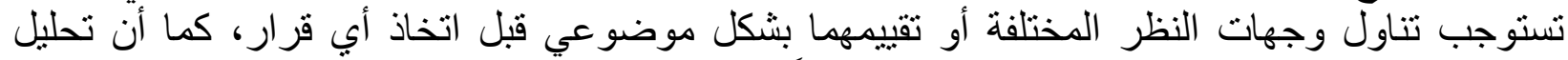

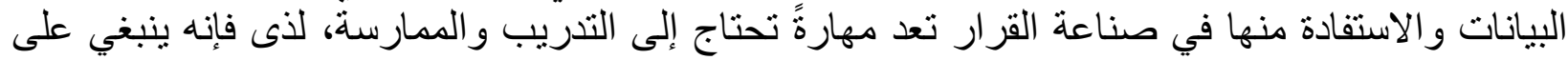

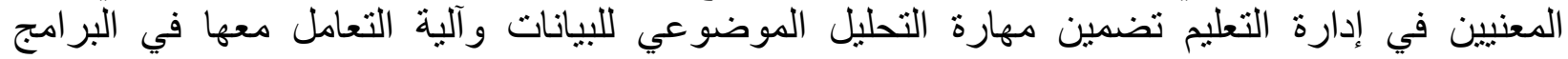
التدريبية المقدمة لقادة المدارس، وذلك لتمكين قادة المدارس من هذه المهارة. 
إجابة السؤال الثاني: " ما مستوى الصحة التظظيمية لاى مدارس التعليم العام في محافظة ينبع من وجهة

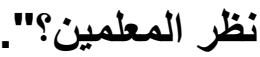
وللإجابة على هذا السؤال، فقد نم حساب المتوسط الحسابي والانحر اف المعياري لأبعاد المحور الثاني

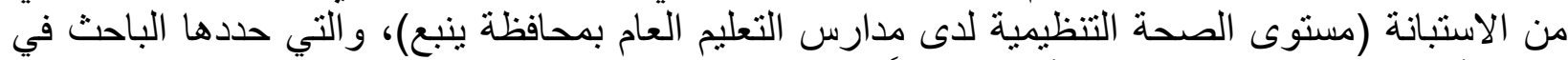

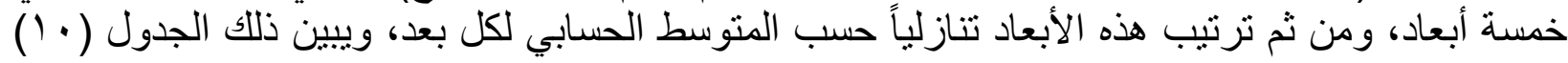

\section{جدول (·) (1) (1)} النالي :

المتوسطات الحسابية والاتحرافات المعيارية لأبعاد المحور الثاني من الاستبانة (مستوى الصحة التنظيمية

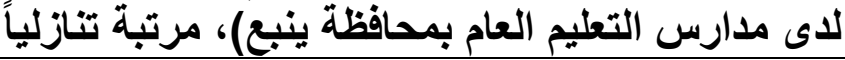

\begin{tabular}{|c|c|c|c|c|c|}
\hline الموافةة & تزيب البعد & الالمعرافياري & المتوسطي & البعد & رقم البعد \\
\hline متوسطة & 1 &.$\wedge 7 \varepsilon$ & T.MT & انتماء المعلم & $\varepsilon$ \\
\hline متوسطة & $r$ & $\cdot \wedge \leqslant \wedge$ & 5.19 & القيادة بالز مالة & $r$ \\
\hline متوسطة & $r$ &.$V Y Y$ & $r .0$ & التأكيد الأكاديمي & 0 \\
\hline متوسطة & $\varepsilon$ &.$\wedge T V$ & r.10 & تأثثبر الموارد & $\mu$ \\
\hline متوسطة & 0 & $\because \vee 9$. & 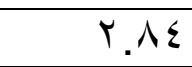 & التكامل المؤسسي & 1 \\
\hline متوسطة & --- &.$V T O$ & $r . \wedge$ & 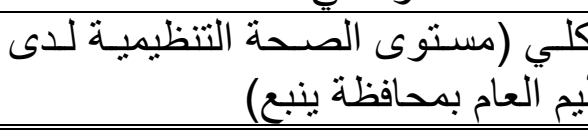 & مدارس التمـوع \\
\hline
\end{tabular}

يتبين من جدول (· ( ) السابق أن مستوى الصحة التنظيمية لاى مدارس التعليم العام بمحافظة ينبع جاء

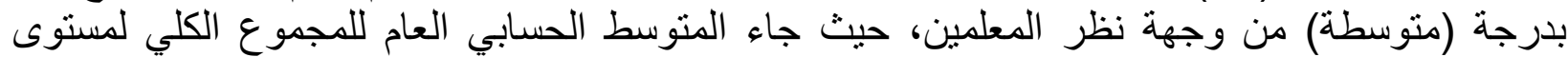

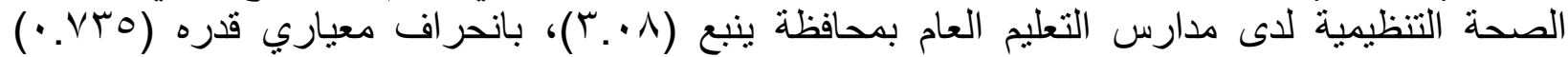

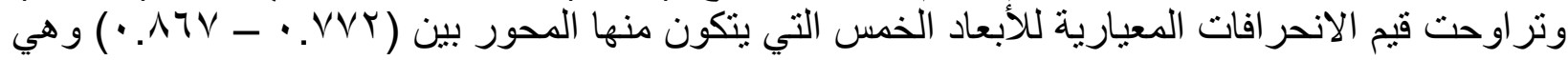

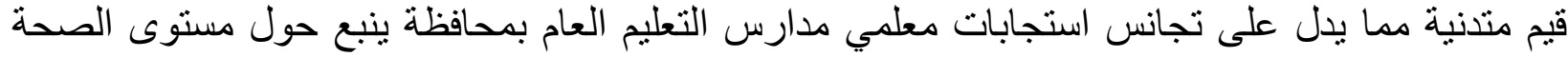

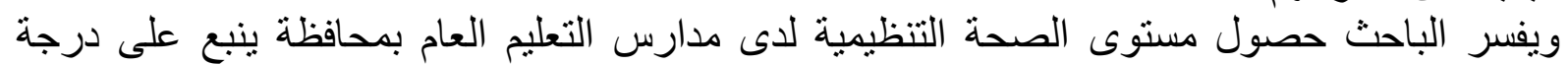

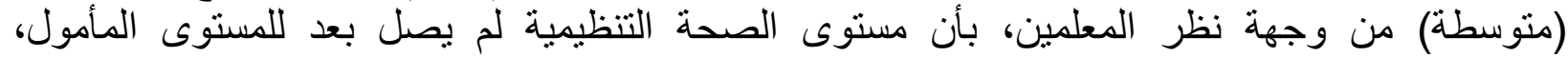

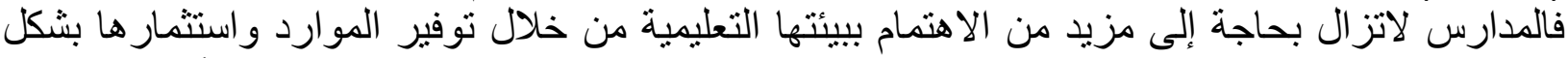

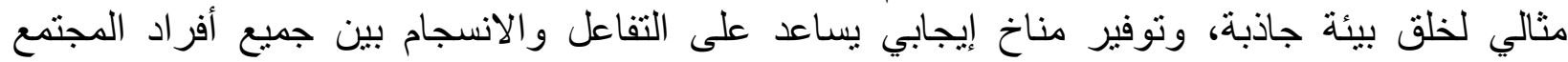
المدرسي ، وهذا يتطلب تكاتف الجهود بين الإدارة العليا وقيادة المدرسة.

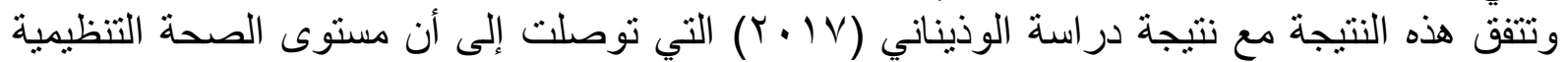

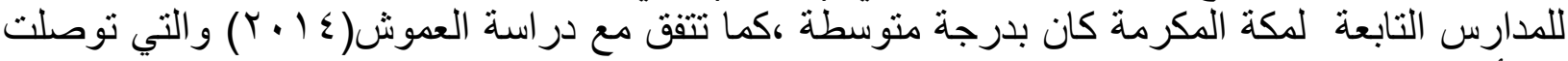

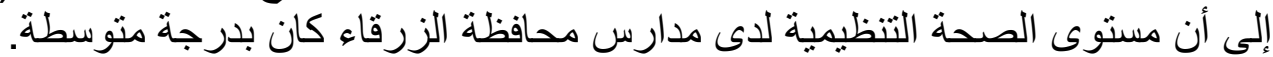

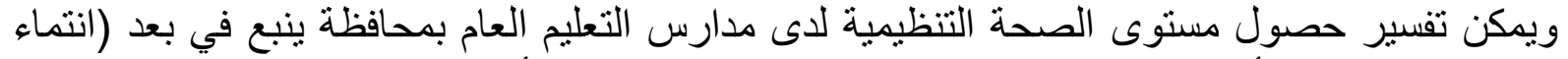

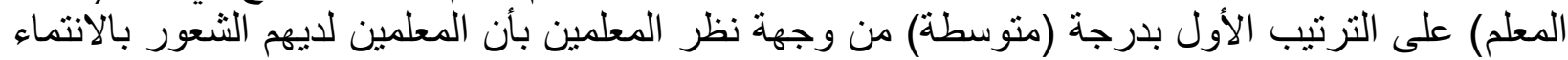

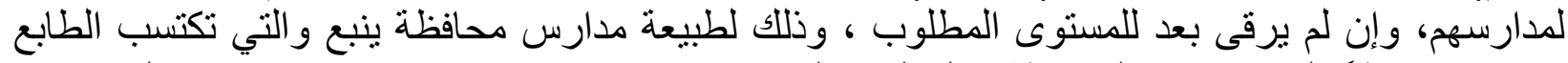
الاجتماعي نظرًا لصغر حجم المحافظة، فالمعلمون لديهم علاقات جيدة مع قادتهم ومع بعضهم داخل وخل وخارج

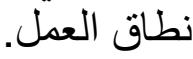
أما حصول مستوى الصحة التنظيمية لدى مدارس التعليم العام بمحافظة ينبع في بعد (التكامل المؤسسي)

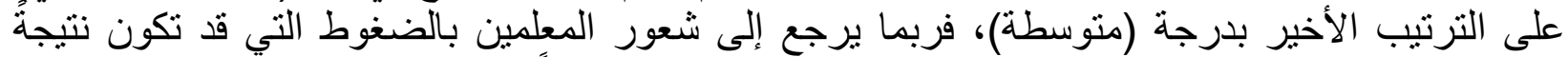

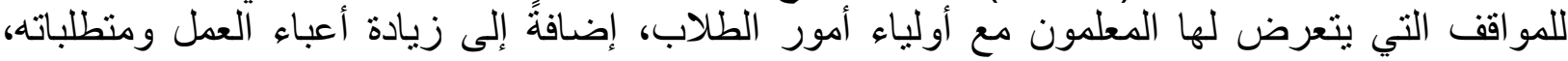

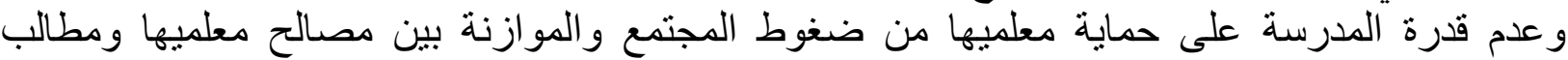


إجابة السؤال الثالث: "هل توجد علاقة ارتباطية ذات دلالة احصائية بين درجة ممارسة قادة مدارس

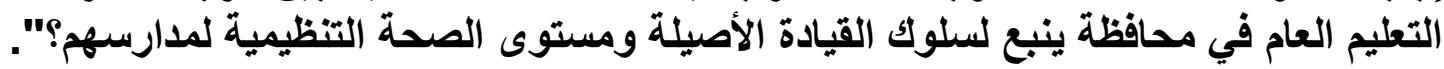

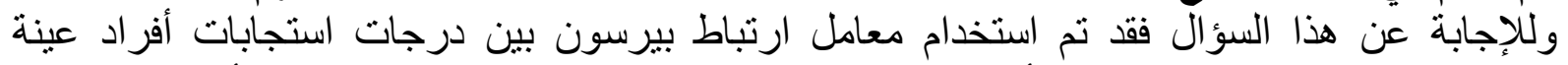

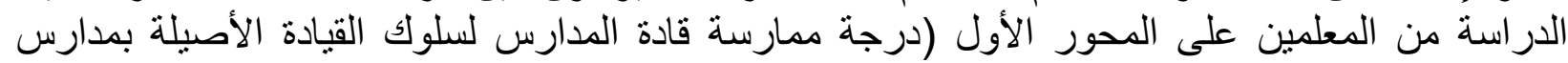

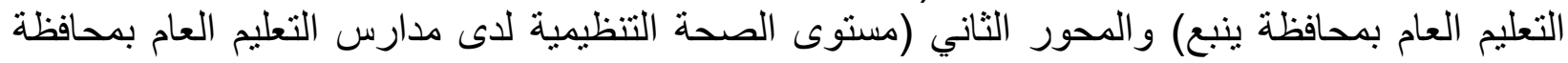

$$
\text { جدول (11) }
$$
ينبع)، وجاءت النتائج كالتالي:

نتائج اختبار بيرسون للعلاقة بين درجة ممارسنة قادة مدارس التعليم العام بمحافظة ينبع لسلوك القيادة

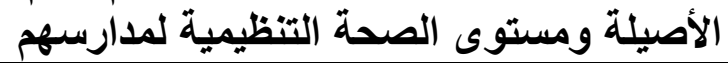

\begin{tabular}{|c|c|c|c|c|}
\hline مستوي & معامل ارتباط بيرسون & المعياري & الحستوسط & المتغيرات \\
\hline \multirow{2}{*}{$* * . \ldots$} & \multirow{2}{*}{$\therefore$} &.$\lambda I T$ & $r . \cdot r$ & بدرجافظة ينبع لسلوة مدار القيادة الأصعيم العام \\
\hline & &.$V T_{0}$ & $r . \cdot 1$ & مستوى الصحلة التنظيمية لدى مدارس \\
\hline
\end{tabular}

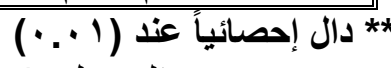

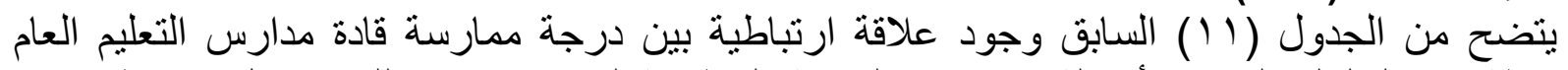

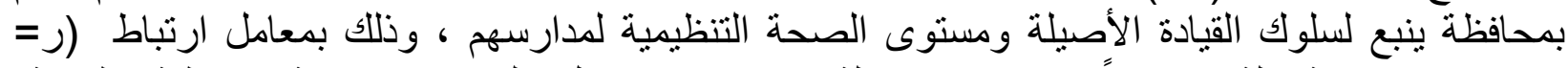
1 1. · ) و هي قيمة دالة إحصائياً عند مستوى دلالة ( ( . · ) مما يدل على وجود علاقة ارتباطية (طردية) عالية القيمة.

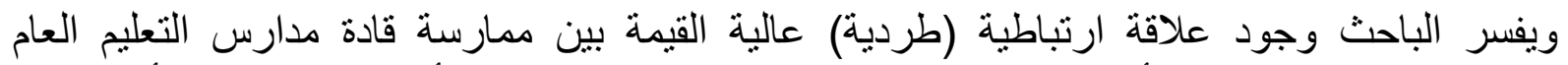

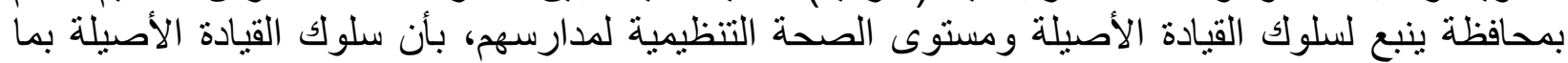

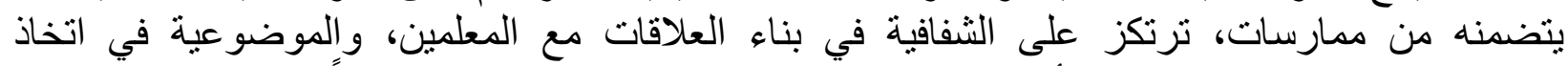

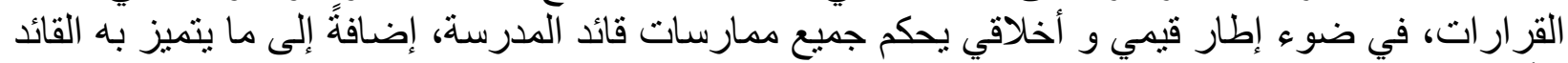

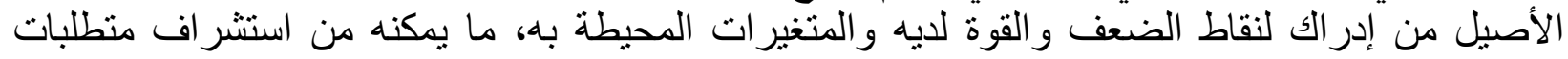

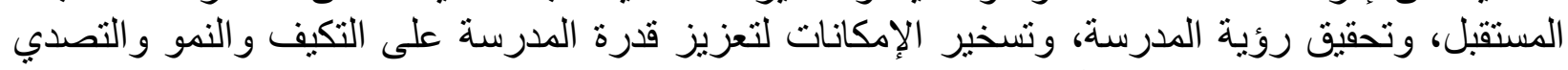

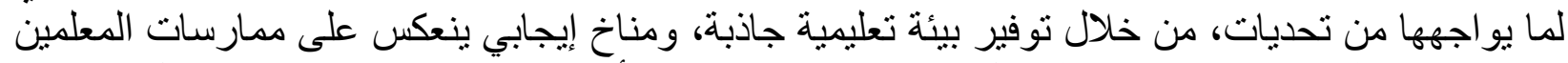

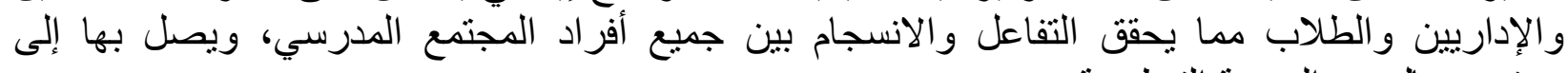
مستوى عالٍ من الصحة التنظيمية.

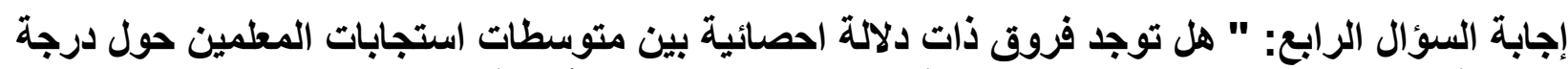

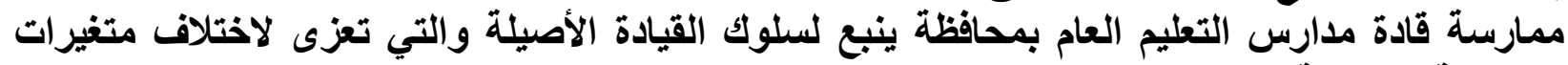
(المرحلة التعليمية، سنوات منات الخبرة)؟".

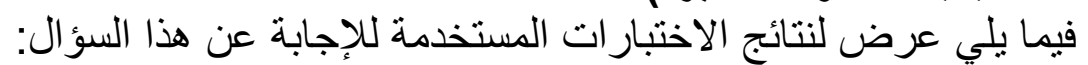

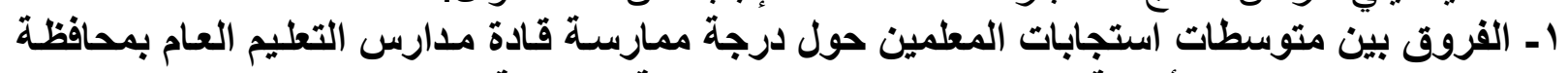

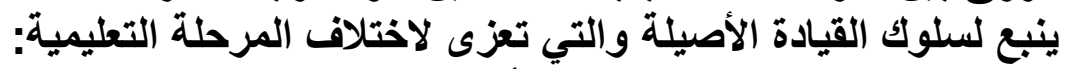

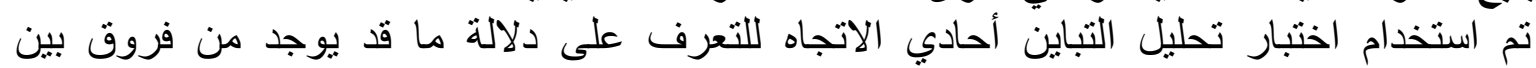

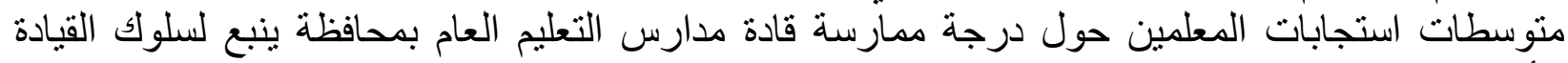

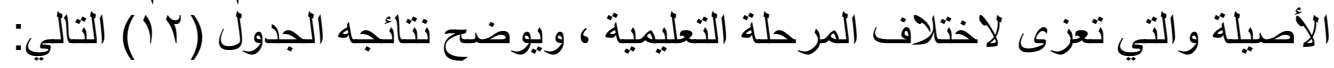


جدول (1)

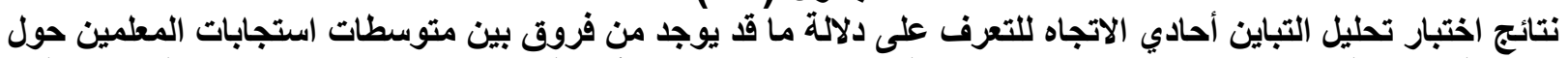
درجة ممارسة قادة مدارس التعليم العام بمحافظة ينبع لسلوك القيادة الأصيلة والتي تعزى لتون لاختلاف المرحلة التعليمية

\begin{tabular}{|c|c|c|c|c|c|c|}
\hline الإحصائية & ف ف & مالمربعات & الحرجية & المجموتات & مصادر التباين & المتفيرات \\
\hline \multirow[t]{3}{*}{${ }^{*} \cdot . .19$} & $\varepsilon \ldots v$ & r.ro & r & 7.79 & بين المجموعات & \multirow{3}{*}{ شففافية العلاقات } \\
\hline & & $\cdot . \wedge \Gamma$ & $r \cdot r$ & ror.91 & داخل المجمو عات & \\
\hline & & & $r .0$ & ro9.TV & الكلي & \\
\hline \multirow[t]{3}{*}{${ }^{* *}, \ldots$} & $0 . \xi 1$. & $\varepsilon . r$ & r & $1 . .0$ & بين المجموعات & \multirow{3}{*}{ المنظور الأخلاقي الداخلي } \\
\hline & &.$V \varepsilon$ & $r \cdot r$ & TYO.O. & داخل المجمو عات & \\
\hline & & & $r .0$ & TrT.00 & الكلي & \\
\hline \multirow[t]{3}{*}{${ }^{*} \cdot . \cdot \Sigma 1$} & $r .9$. & $\overline{r . r \xi}$ & $\bar{T}$ & $\varepsilon .71$ & بين المجموعات & \multirow{3}{*}{ المعالجة الثنوازئة : } \\
\hline & & 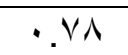 & $r \cdot r$ & TMO.T\& & داخل المجمو عات & \\
\hline & & & $r .0$ & $T \varepsilon \cdot, r Y$ & الكلي & \\
\hline \multirow[t]{3}{*}{${ }^{* \star} \cdot \ldots l$} & $V . \varepsilon r \leqslant$ & $0 . \leqslant \leqslant$ & r & $1 \cdot . \wedge \mathrm{V}$ & بين المجموعات & \multirow{3}{*}{ البعد الرابع : } \\
\hline & & $\cdot . v \mu$ & $r \cdot r$ & YYI.T. & داخل المجموعات & \\
\hline & & & $r .0$ & TrY.\&V & الكلي - الكي & \\
\hline \multirow[t]{3}{*}{ **... } & $0.71 \mathrm{~V}$ & r. & $\bar{T}$ & $\overline{V . Y I}$ & بين المجموعات & \multirow{3}{*}{ المجموع الكلي } \\
\hline & & $.7 \varepsilon$ & $r . r$ & $19 \varepsilon . \% V$ & داخل المجموعات & \\
\hline & & & $r .0$ & $Y .1 .0 V$ & الكلي & \\
\hline
\end{tabular}

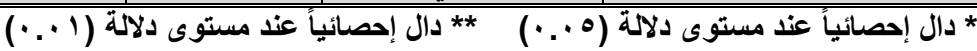

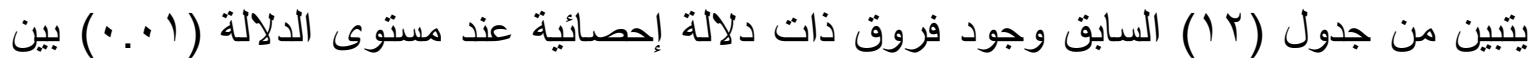

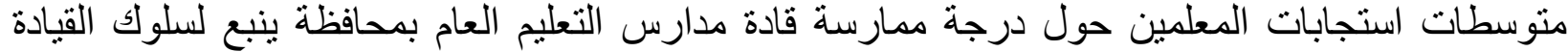
الأصيلة و التي تعزى لاختلاف المرحلة التعليمية.

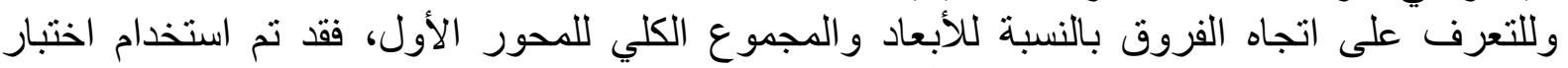

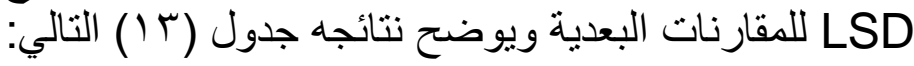

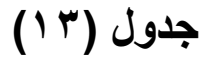

نتائج اختبار LSD للمقارنات البعدية لمعرفة اتجاه الفروق بين متوسطات استجابات المعلمين حول تقايرهم لارجة

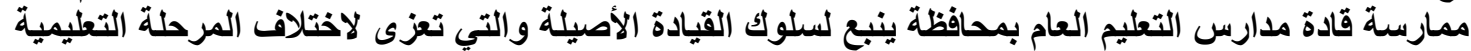

\begin{tabular}{|c|c|c|c|c|c|c|}
\hline الثانوية & المتوسطة & الابتدائية & الحستوسي & العدد & المرحلة التعليمية & المتغير \\
\hline & & -.-- & $r .97$ & 101 & الابتدائية & \multirow{3}{*}{ شفافية العلاقات } \\
\hline & --- & & $r .94$ & NT & المتوسطة & \\
\hline \multirow[t]{3}{*}{$-\cdots$} & $* . . \mu \wedge$ & $* .$. ro $^{\circ}$ & $r . \mu$ & 77 & الثانوية & \\
\hline & & --- & T.9 & 101 & الابتدائية & \multirow{3}{*}{ 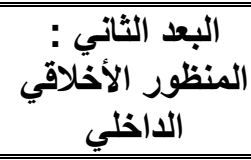 } \\
\hline & --.- & & Y.qV & AT & المتوسطة & \\
\hline \multirow[t]{3}{*}{$-\cdots$} & $* * ., \mu V$ & **.. & $r . r \varepsilon$ & 77 & الثانوية & \\
\hline & & 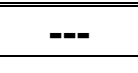 & Y.AV & 101 & الابتدائية & \multirow{3}{*}{ المعالجة الثتّالث : } \\
\hline & --- & & Y.q. & $\lambda T$ & المتوسطة & \\
\hline \multirow[t]{3}{*}{$\cdots$} & ${ }^{*} \cdot . \mathrm{YA}$ & $* . . r 1$ & $r .11$ & 74 & الثانوية & \\
\hline & & --.- & 5.91 & 101 & الابتدائية & \multirow{3}{*}{ الوعي الذانتي : } \\
\hline & --- & & $r . \cdot v$ & AT & المتوسطة & \\
\hline \multirow[t]{3}{*}{--} & ${ }^{* *} . \mu^{\mu}$ & **.. $\{9$ & T.\&. & 77 & الثانوية & \\
\hline & & --.- & Y. . & 101 & الابتدائية & \multirow{3}{*}{ المجموع الكلي } \\
\hline & --- & & T.9V & $\lambda T$ & المتوسطة & \\
\hline--- & $* * ., \Gamma \leqslant$ & $* * . \mu q$ & $r . \mu$ & 77 & الثانوية & \\
\hline
\end{tabular}

* دال إحصائياً عند مستوى دلالة (0.. *) ** دال إحصائياً عثد مستوى دلالة (1 . .) 


$$
\text { يتبين من جدول (ب ا (1) السابق ما يلي: }
$$

- توجد فروق ذات دلالة إحصائية عند مستوى الدلالة (1 (•. ·) بين متوسطات استجابات المعلمين

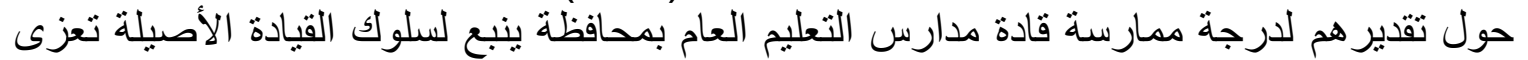

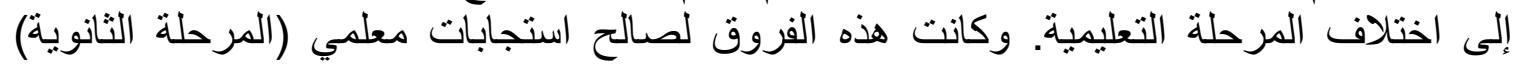

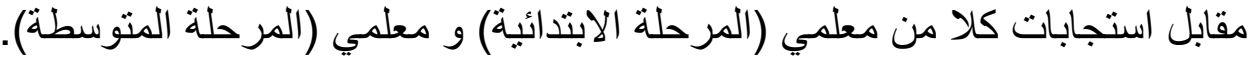

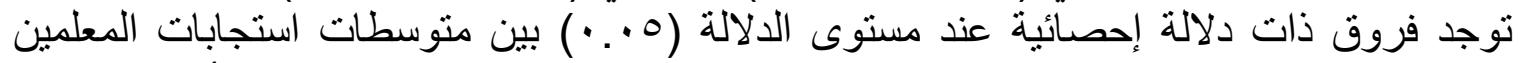

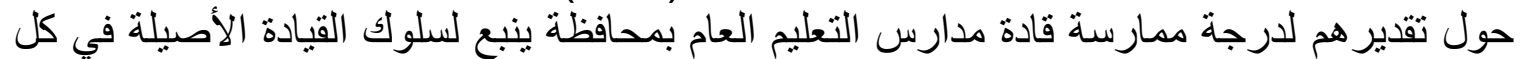

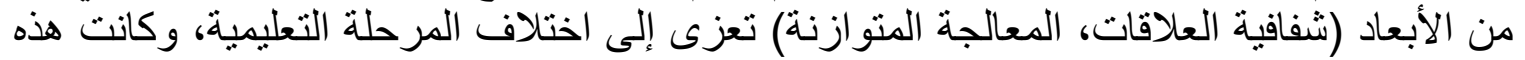

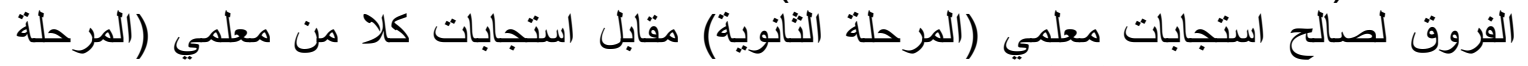
الابتدائية) و معلمي (المرحلة المتوسطة). توجد فروق ذات دلالة إحصائية عند مستوى الدلالة (1 •. • ) بين متوسطات استجابات المعلمين

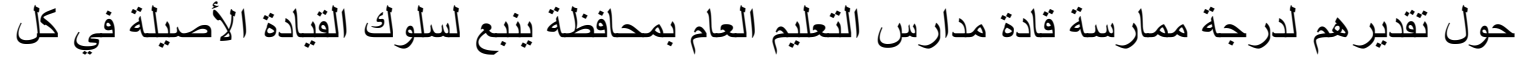

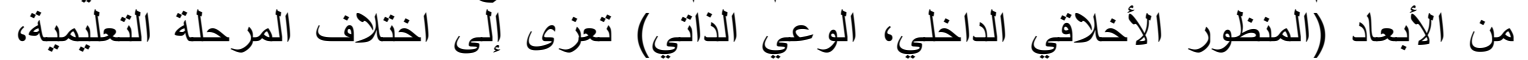

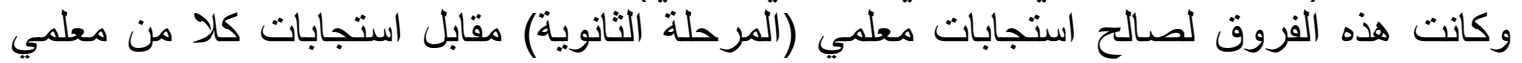

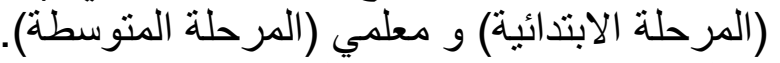

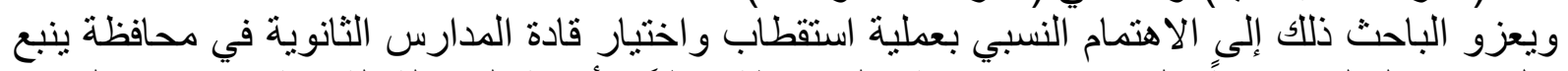

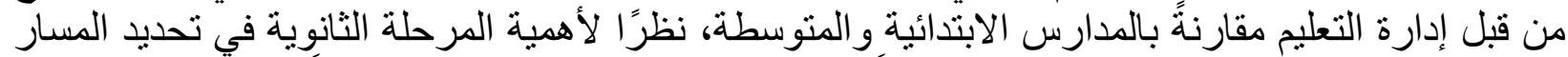

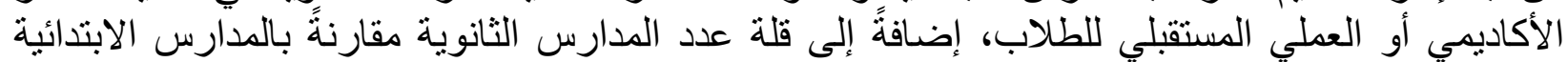

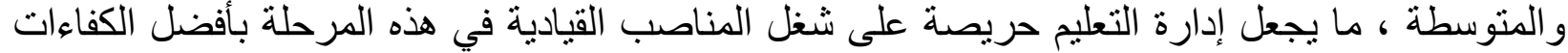

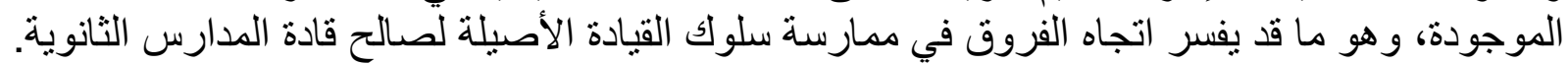

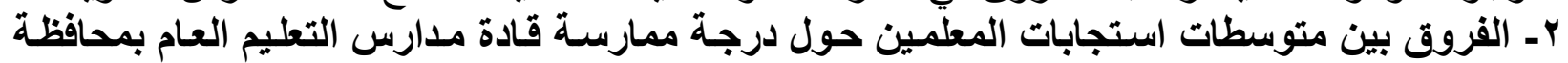

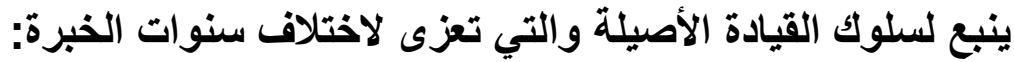

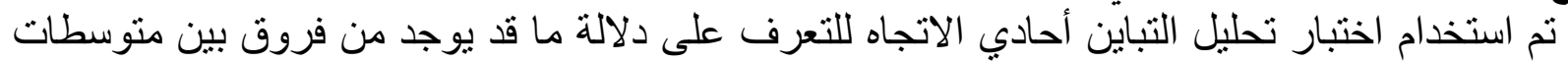

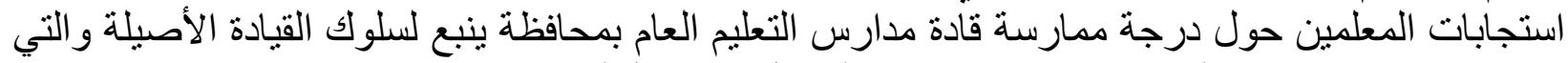
تعزى لاختلاف سنوات الخبرة ، ويوضح نتائجه الجدول (ع ( ) التالي: جذول (1 ) (1)

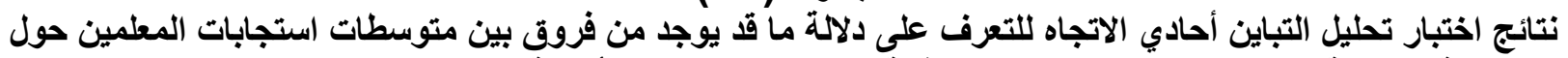

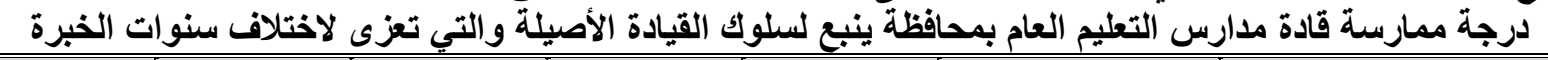

\begin{tabular}{|c|c|c|c|c|c|c|}
\hline الإحصائية & ف & مالمرتسط & الدرجية & المربعوت & مصادر التباين & المتغيرات \\
\hline \multirow[t]{3}{*}{${ }^{* *}, \ldots v$} & $\varepsilon .9 V V$ & $\varepsilon .1 \%$ & $\overline{T r}$ & $1 . Y 7$ & بين المجموعات & \multirow{3}{*}{ شفافية العلاقات } \\
\hline & & $\cdot . \wedge \Gamma$ & $r . r$ & Y01.ह1 & داخل المجمو عات & \\
\hline & & & $r .0$ & ro9.7V & الكلي - الكي & \\
\hline \multirow[t]{3}{*}{${ }^{*} \cdot . \cdot r \Lambda$} & T. . QY & r. ¿A & $r$ & $\varepsilon .9 \mathrm{~V}$ & بين المجموعات & \multirow{3}{*}{ المنظور الأخلاقي الداخلي } \\
\hline & & $\because .10$ & $r . r$ & rYA.01 & داخل المجموعات & \\
\hline & & & $r .0$ & TRT.00 & الكلي & \\
\hline \multirow[t]{3}{*}{. .111} & r. $1 \leqslant 9$ & 1.71 & $\bar{r}$ & T.r4 & بين المجموعات & \multirow{3}{*}{ المعالجة الثنتوازنة } \\
\hline & &.$\vee \wedge \wedge$ & $r \cdot r$ & TrY.97 & داخل المجموعات & \\
\hline & & & $r .0$ & $Y \varepsilon \cdot, T Y$ & الكلي & \\
\hline \multirow[t]{3}{*}{$\because .10$} & 1.9 .9 & $1 . \leqslant 0$ & $\bar{r}$ & T.19 & بين المجموعات & \multirow{3}{*}{ البعي الأاتيع : } \\
\hline & & $\cdot . \mathrm{VI}$ & $r \cdot r$ & rrq.01 & داخل المجموعات & \\
\hline & & & $r .0$ & TrY.SV & الكلي - الكي & \\
\hline \multirow[t]{3}{*}{${ }^{*} \cdot . \cdot r 1$} & r.or. & r.rq & $\bar{r}$ & $\varepsilon .01$ & بين المجموعات & \multirow{3}{*}{ المجموع الكلي } \\
\hline & & .70 & $r \cdot r$ & $19 V . .$. & داخل المجموعات & \\
\hline & & & $r .0$ & $r .1 .0 V$ & الكلي & \\
\hline
\end{tabular}

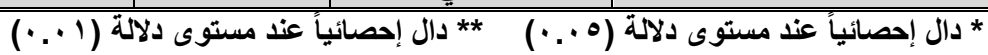


يتبين من جدول (ع () السابق وجود فروق ذات دلالة إحصائية عند مستوى الدلالة (0. . •) بين

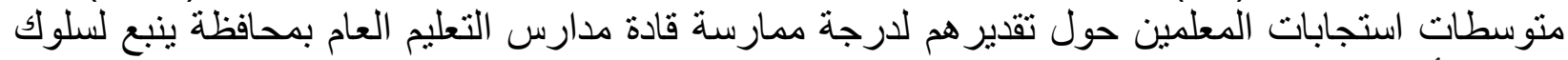

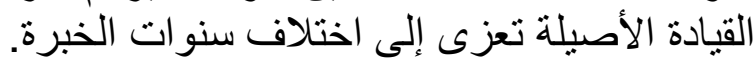

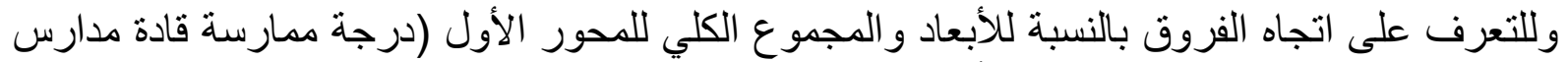

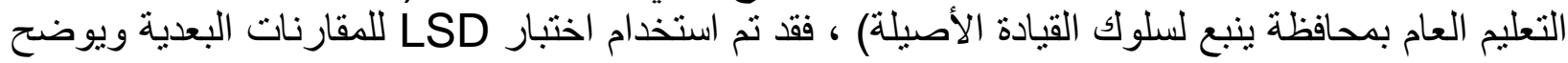

\section{جدول (10) (10)} نتائجه جدول (0 1 ) التالي:

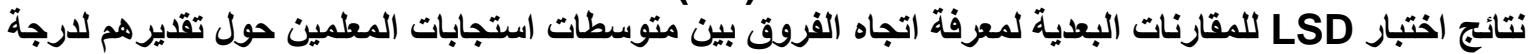

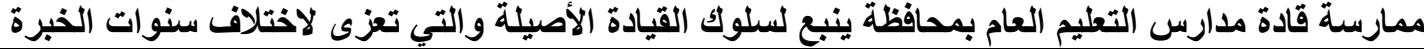

\begin{tabular}{|c|c|c|c|c|c|c|}
\hline فأكثر سنة & أقل من · من إلى & أقل من • & المستوسطي المسبي & 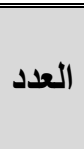 & سنوات الخبرة & المتغير \\
\hline & & 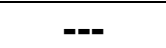 & T.AY & $1 . r$ & أقل من · ا سنو ات & \multirow{3}{*}{ شفافية العلاقات الأول : البعات } \\
\hline & $\boldsymbol{m}$ & & $r . \Lambda$ & 101 & من · ا إلى أقل من · ب سنة & \\
\hline \multirow[t]{3}{*}{--} & & $* * . . \varepsilon V$ & r.Yq & 0 . & r r سنة فأكثر & \\
\hline & & $=-$ & 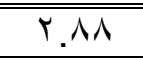 & $1 \cdot r$ & أقل من · ا سنو ات & \multirow{3}{*}{ المنظور الأخلاقي } \\
\hline & -- & & $r . v$ & 104 & من · ا إلى أقل من · ب سنة & \\
\hline \multirow[t]{3}{*}{--} & & $* . \mu V$ & r. ro & 0. & • r سنة فأكثر & \\
\hline & & $\begin{array}{ll}-+ \\
\end{array}$ & $r . \wedge 7$ & $1 \cdot r$ & أقل من · ا سنو ات & \multirow[t]{3}{*}{ المجموع الكلي } \\
\hline & -- & & $r .7$ & 104 & من • إلى أقل من • r سنة & \\
\hline-- & & $* ., r \varepsilon$ & r. & 0. & • r سنة فأكثر & \\
\hline
\end{tabular}

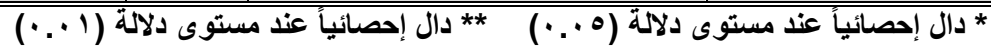

يتبين من جدول (0 إن ) السابق ما يلي:

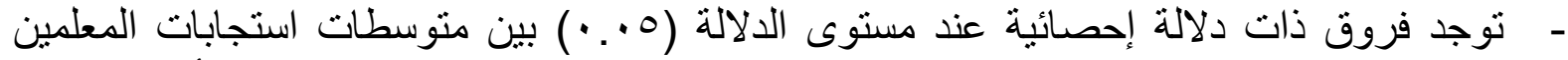

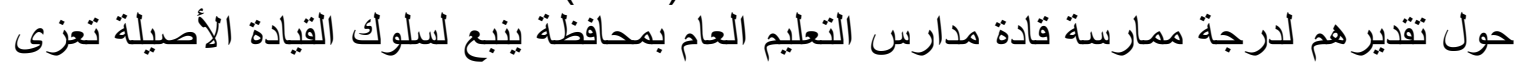

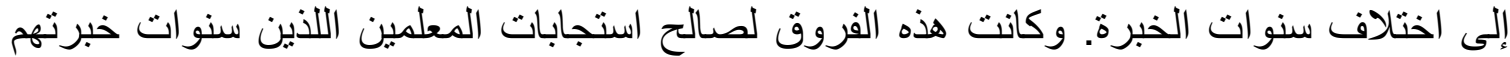

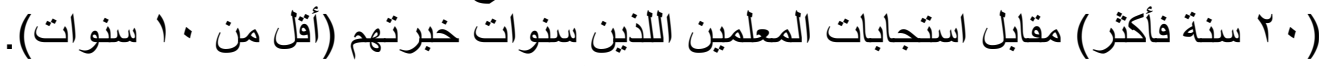
- توجد فروق ذات دلالة إحصائية عند مستوى الدلالة (1 (. · ) بين متوسطات استجابات المعلمين

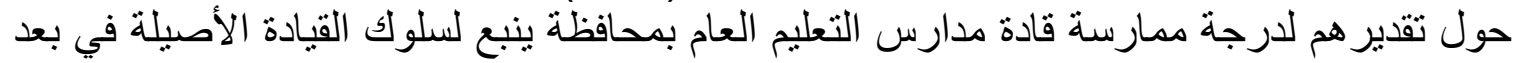

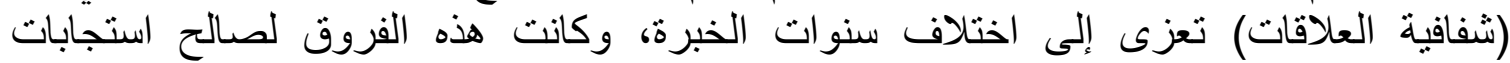

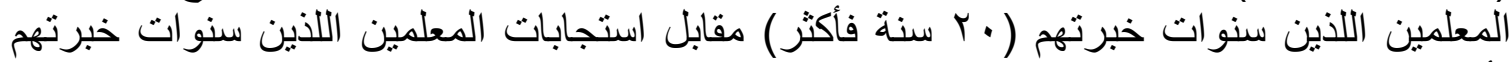

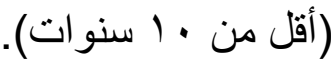
- توجد فروق ذات دلالة إحصائية عند مستوى الدلالة (0. . • ) بين متوسطات استجابات المعلمين

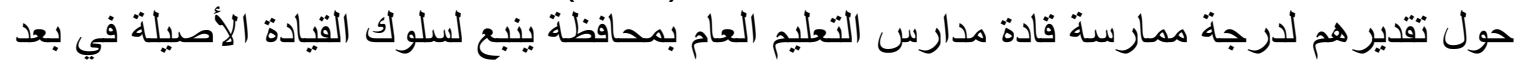

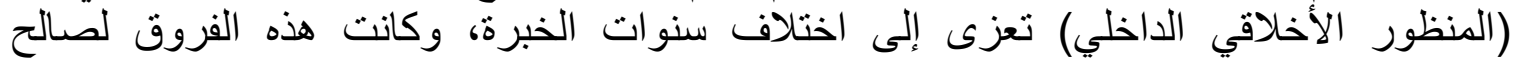

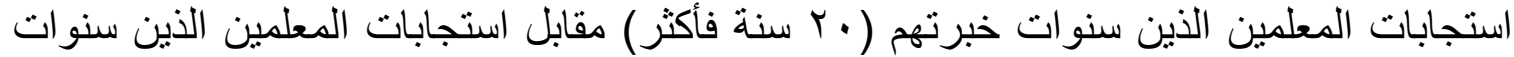

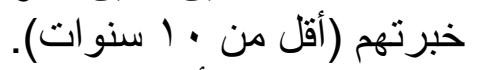

ويفسر الباحث ذلك بأن المعلمين الذين سنوات خبرتهم (· · سنة فأكثر) يينون تصور اتهم من خلادل

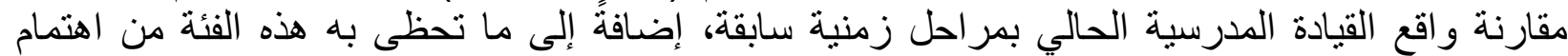

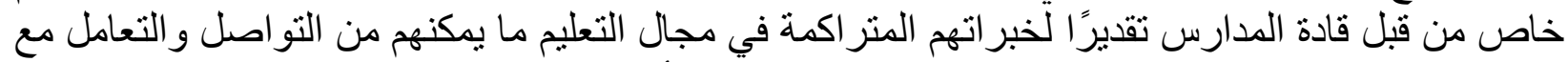

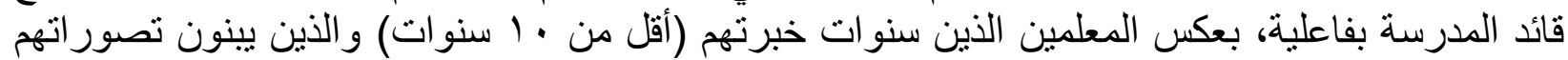

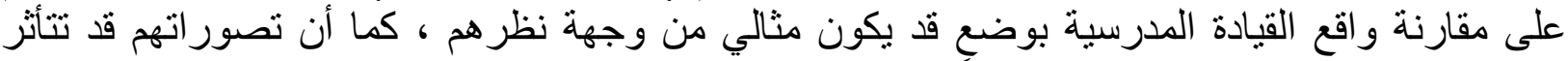

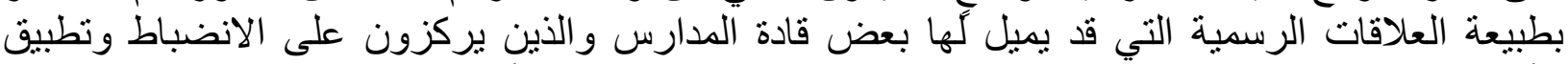
الأنظمة مايجعل التعامل بين قائد المدرسة والمعلمين من حديثي الخبرة يأخذ الطابع الرسمي في التو اصلي الركل. 
إجابة السؤال الخامس: "هل توجد فروق ذات دلالة احصائية بين متوسطات استجابات معلمي مدارس

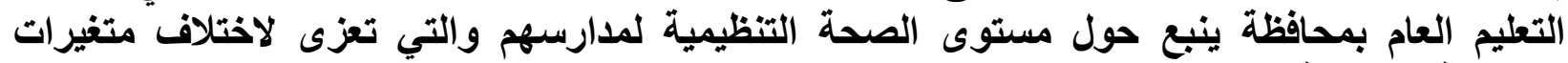

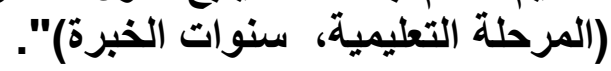

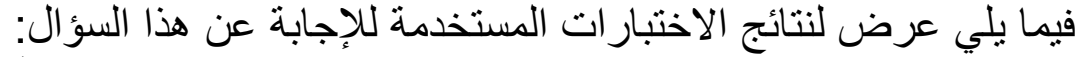

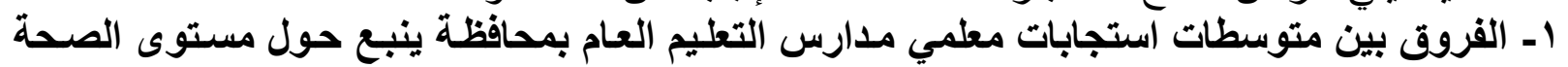

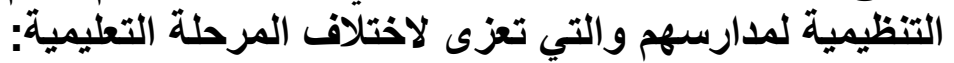

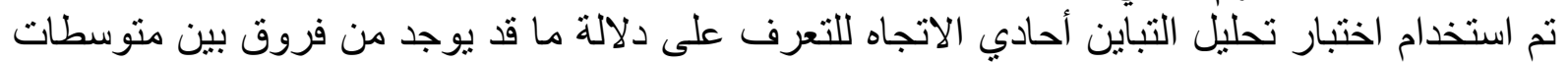

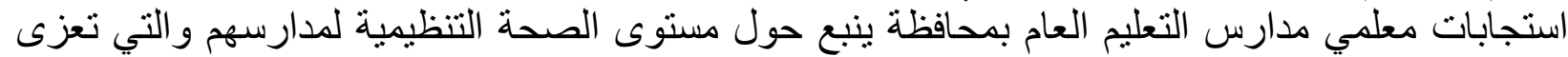

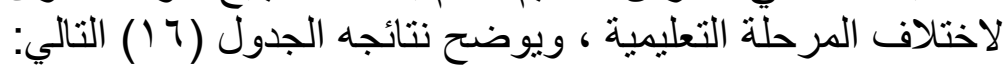

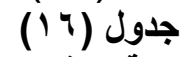

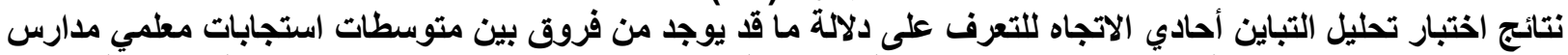

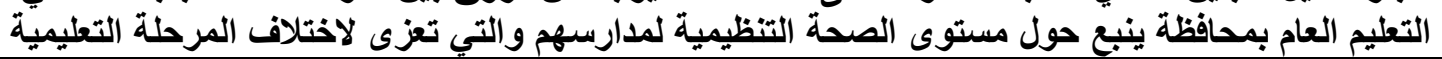

\begin{tabular}{|c|c|c|c|c|c|c|}
\hline الإحصائية & ف & المتوبعات & الحرية & المربعات & مصادر التباين & المتغيرات \\
\hline$*$ *..YY & $\Gamma . \wedge \vee \varepsilon$ & r.rV & $r$ & $\varepsilon . V \varepsilon$ & بين المجموعات & \multirow{3}{*}{ التكامل البعد الأول : } \\
\hline & & .71 & $r \cdot r$ & $110 . r 9$ & داخل المجموعات & \\
\hline & & & $r .0$ & $19 \cdot .1 \%$ & الكلي & \\
\hline \multirow[t]{3}{*}{ **...r } & 7.110 & $\varepsilon . \mu q$ & $\bar{r}$ & ᄉ.VA & بين المجموعات & \multirow{3}{*}{ القيادة بالزمالية } \\
\hline & & $\because V \cdot$ & $r \cdot r$ & $Y 1 \cdot .09$ & داخل المجموعات & \\
\hline & & & $r .0$ & $r 19 . r v$ & الكلى & \\
\hline \multirow[t]{3}{*}{$* . . \leq 7$} & T.IT. & T.M & $\bar{r}$ & ร.7T & بين المجموعات & \multirow{3}{*}{ تأثير الموارد الثالث : } \\
\hline & & $. V \leqslant$ & $r \cdot r$ & YYE.TV & داخل المجموعات & \\
\hline & & & $\Gamma .0$ & rYq.r. & الكلى & \\
\hline \multirow[t]{3}{*}{ **..1. } & E.VYT & $r . \leqslant 0$ & Tr & $7 . \wedge 9$ & بين المجموعات & \multirow{3}{*}{ البتعد الرابع : المعلم } \\
\hline & &.$V \Gamma$ & $\Gamma \cdot r$ & $r Y \cdot . \wedge q$ & داخل المجموعات & \\
\hline & & & $r .0$ & YYV.Vq & الكلي & \\
\hline \multirow[t]{3}{*}{$.1 \leqslant \wedge$} & $1.9 Y r$ & $1.1 \varepsilon$ & $\bar{Y}$ & r.YA & بين المجموعات & \multirow{3}{*}{ التأكيد الأكاديمي : } \\
\hline & & .09 & $r \cdot r$ & IV9.0r & داخل المجموعات & \\
\hline & & & $r .0$ & $1 \wedge 1 . \wedge$. & الكلي & \\
\hline \multirow[t]{3}{*}{ **.... } & $0 . \leq 71$ & r.^T & $\bar{r}$ & $0 . V T$ & بين المجموعات & \multirow{3}{*}{ المجموع الكلي } \\
\hline & & $.0 Y$ & $r \cdot r$ & 101.AT & داخل المجموعات & \\
\hline & & & $r .0$ & $17 \varepsilon .07$ & الكلي & \\
\hline
\end{tabular}

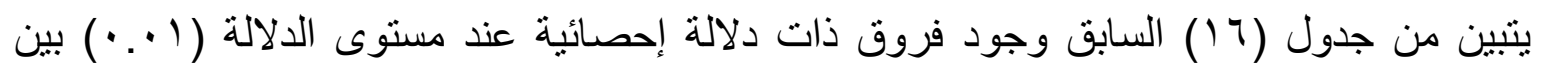
متوسطات استجابات معلمي مدارس التعليم العام بمحافظة ينبع حول مستوى الصحة التهات التنظيمية لمدارسهم تعزى إلى اختلاف المرحلة التعليمية. وللتعرف على اتجاه الفروق بالنسبة للأبعاد والمجموع الكلي للمحور الثاني (مستوى الصحة التنظيمية

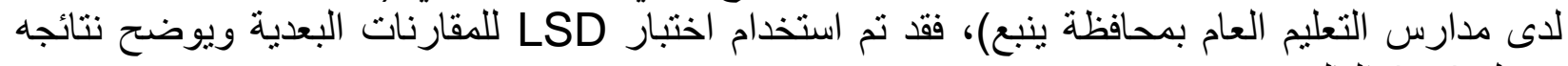

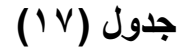

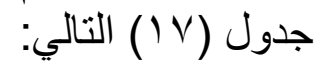
نتائج اختبار LSD للمقارنات البعدية لمعرفة اتجاه الفروق بين متوسطات استجابات معلمي مدارس التطليم العام بمحافظة ينبع حول مستوى الصحة التنظيمية لددارسهم والتي تعزى لاختلاف المرحلة التطليمية التئية

\begin{tabular}{|c|c|c|c|c|c|c|}
\hline الثانوية & المتوسطة & الابتدائية & الكستوسب & العدد & المرحلة التعليمية & المتغير \\
\hline & & -.-- & r.vo & 101 & الابتدائية & \multirow{3}{*}{ التكامل المؤسسكي } \\
\hline & --- & & T.AY & $\Delta r$ & المتوسطة & \\
\hline --- & & ${ }^{*} . . Y Y$ & $r . v$ & 77 & الثنانوية & \\
\hline
\end{tabular}




\begin{tabular}{|c|c|c|c|c|c|c|}
\hline الثانوية & المتوسطة & الابتدائية & الحستوسي & العدد & المرحلة التعليمية & المتفير \\
\hline & & --- & $r .0$ & 101 & الابتدائية & \multirow{3}{*}{ القيادة بالزمالة الثاني } \\
\hline & --- & & r.YI & NT & المتوسطة & \\
\hline \multirow[t]{3}{*}{---} & $* . . Y V$ & ${ }^{* *}, . \leqslant \mu$ & $r . \leqslant 9$ & 77 & الثانوية & \\
\hline & & ב-- & T.VO & 101 & الابتدائية & \multirow{3}{*}{ تأثير الموارد الثالث : } \\
\hline & --- & & T.AV & NT & المتوسطة & \\
\hline \multirow[t]{3}{*}{$-\cdots$} & & $* . . r Y$ & $r . V$ & 77 & الثانوية & \\
\hline & & --- & r.YI & 101 & الابتدائية & \multirow{3}{*}{ البتماء المعلم : الرابع } \\
\hline & --- & & T.T & NT & المتوسطة & \\
\hline \multirow[t]{3}{*}{---} & $* . . Y \Lambda$ & $* * ., r \Lambda$ & $r .09$ & 77 & الثانوية & \\
\hline & & ב--- & r.91 & 101 & الابتدائية & \multirow[t]{3}{*}{ المجموع الكلي } \\
\hline & --- & & $r .9$ & NT & المتوسطة & \\
\hline--- & $* ., Y \varepsilon$ & **. r. & איזי & 77 & الثانوية & \\
\hline
\end{tabular}

* دال إحصائياً عند مستوى دلالة (0 .. ) * * دال إحصائياً عند مستوى دلالة (1 . •)

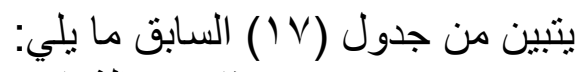

- توجد فروق ذات دلالة إحصائية عند مستوى الدلالة (1 ( . • ) بين منوسطات استجابات معلمي مدارس التعليم العام بمحافظة بنبع حول مستوى الصحة التنظيمية لمدارسهم تعزى إلى اختلاف المرحلة التعليمية. وكانت هذه الفروق لصالح استجابات معلمي (المرحلة الثانوية) مقابل استجابات كلا من معلمي (المرحلة الابتدائية) و معلمي هلة وفئة (المرحلة المتوسطة).

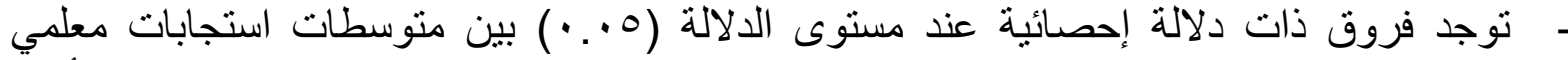

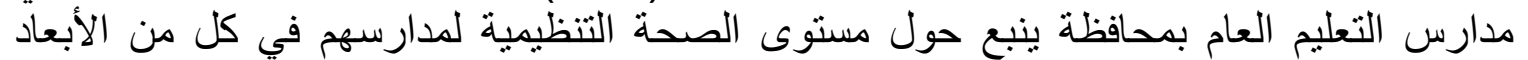

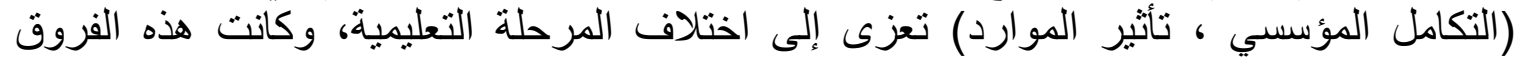

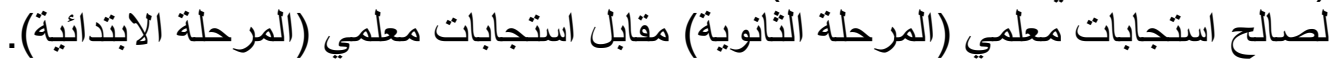

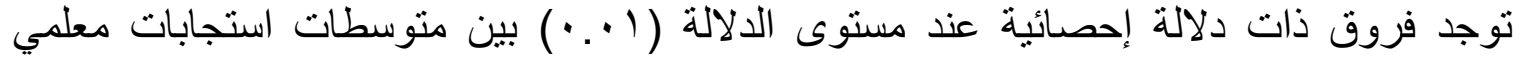
مدارس التعليم العام بمحافظة ينبع حول مستوى الصحة التهات التنظيمية لمدارسهم في كل من من الأبعاد

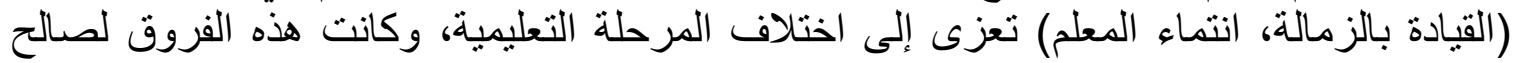
استجابات معلمي (المرحلة الثانوية) مقابل استجابات كلا من معلمي (المرحلة الابتدائية) و معلمي (المرحلة المتوسطة). ويفسر الباحث وجود الفروق في استجابات المعلمين حول تقدير هم لمستوى الصحة التنظيمية لمدارسهم،

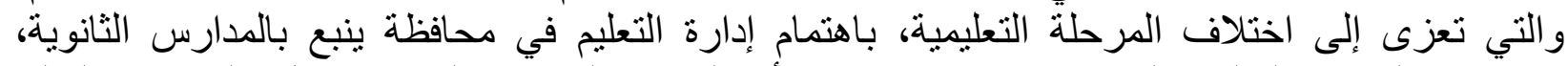

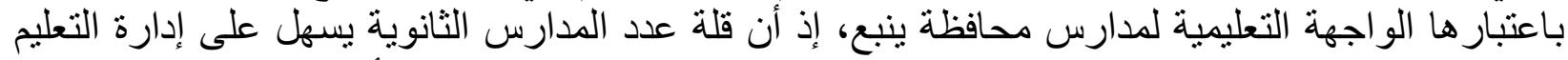

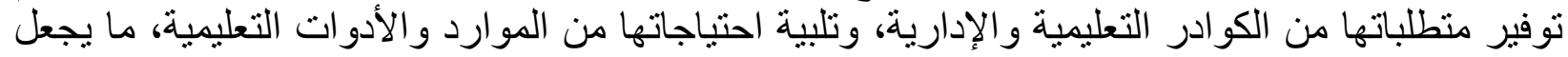

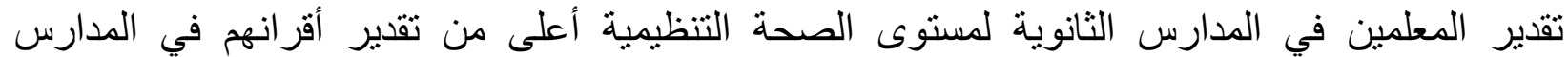
الابتدائية و المتوسطة.

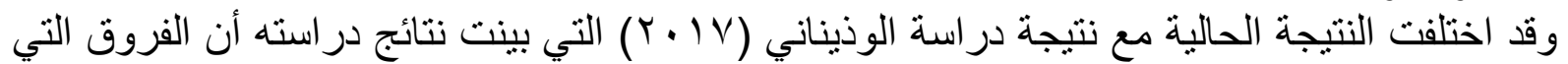
تعزى للمرحلة التعليمية كانت لصالح المرحلة الابتدائية. ويعزى الاختلاف في النية النتائج إلى الاختلاف في بيئة الدر اسة ومجتمعها. rـ الفروق بين متوسطات استجابات معلمي مدارس التعليم العام بمحافظة ينبع حول مستوى الصحة

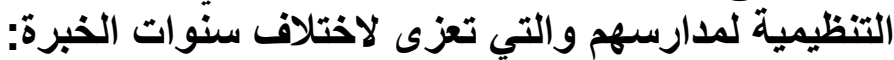

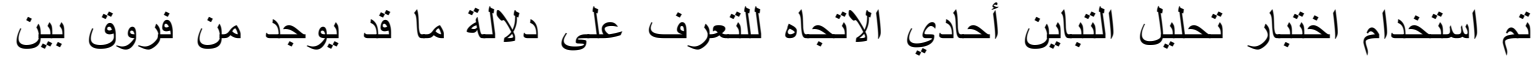
متوسطات استجابات معلمي مدارس التعليم العام بمحافظة ينبع حول مستوى الصحة التحاه التظظيمية لمدارسهر

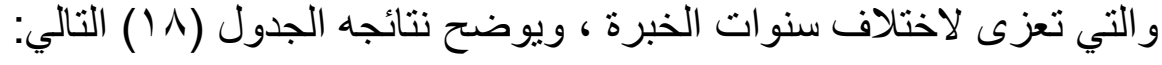


جدول (11)

نتائج اختبار تحليل التباين أحادي الاتجاه للتعرف على دلالة ما قد يوجد من من فروق بئ بين متوسطات استجابات معلمي مدارس

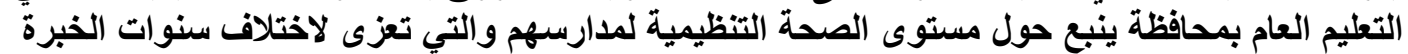

\begin{tabular}{|c|c|c|c|c|c|c|}
\hline الإحصائية & ف & المتربعات & الحرية & المربعات & مصادر التباين & المتغيرات \\
\hline \multirow[t]{3}{*}{ 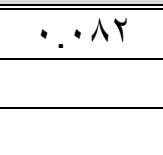 } & r.OYT & 1.07 & $\bar{r}$ & 5.11 & بين المجموعات & \multirow{3}{*}{ التكامل المؤسسي الأول : } \\
\hline & &. .74 & $r \cdot r$ & $1 \wedge v_{.} \cdot 1$ & داخل المجموعات & \\
\hline & & & $r .0$ & $19 . .11$ & الكلي & \\
\hline \multirow[t]{3}{*}{$* . .49$} & T.YVE & T.MT & $r$ & $\varepsilon .7 \varepsilon$ & بين المجموعات & \multirow{3}{*}{ القيادة بالزمالية الثاني } \\
\hline & &.$V 1$ & $r \cdot r$ & $r) \varepsilon . V T$ & داخل المجموعات & \\
\hline & & & $r .0$ & r) $9 . r v$ & الكلي & \\
\hline \multirow[t]{3}{*}{. .899} & . YYS &. $.1 \mathrm{~V}$ & $\bar{r}$ & $\cdot . \Gamma \xi$ & بين المجموعات & \multirow{3}{*}{ تأثير الموارد الثالث : } \\
\hline & &. .17 & $r \cdot r$ & YYA. 97 & داخل المجموعات & \\
\hline & & & $r .0$ & rYq.r. & الكلي & \\
\hline \multirow[t]{3}{*}{${ }^{* *} \cdot \ldots 7$} & $0 . Y Y A$ & $\Gamma . \wedge$. & $r$ & V.7. & بين المجموعات & \multirow{3}{*}{ البتماء الرابع : } \\
\hline & &..$V T$ & $r \cdot r$ & $r r \cdot .19$ & داخل المجموعات & \\
\hline & & & $r .0$ & rrV.Vq & الكلي & \\
\hline \multirow[t]{3}{*}{. $.1 \% \varepsilon$} & r.PI & $1 . Y$. & $\bar{r}$ & Y.s. & بين المجموعات & \multirow{3}{*}{ التأكيد الأكاديمي : } \\
\hline & & .09 & $r \cdot r$ & $1 \vee 9 . \varepsilon$. & داخل المجموعات & \\
\hline & & & $r .0$ & $\mid \wedge ! . \wedge$. & الكلي & \\
\hline \multirow[t]{3}{*}{${ }^{*} \cdot . \cdot \varepsilon \Gamma$} & $r .1 V \varepsilon$ & 1.79 & $\bar{r}$ & r.r人 & بين المجمو عات & \multirow{3}{*}{ المجموع الكلي } \\
\hline & & .04 & $r \cdot r$ & 171.11 & داخل المجموعات & \\
\hline & & & $r .0$ & $17 \varepsilon .07$ & الكلي & \\
\hline
\end{tabular}

يتبين من جدول (1 (1) السابق وجود فروق ذات دلالة إحصائية عند مستوى الدلالة (0. . • ) بين

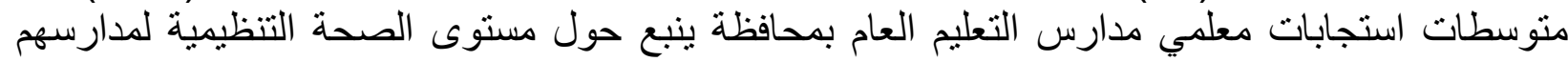
تعزى إلى اختلاف سنو ات الخبات الخبرة وللتعرف على اتجاه الفروق بالنسبة للأبعاد والمجموع الكئل الكلي للمحور الثاني (مستوى الصحة التنظيمية

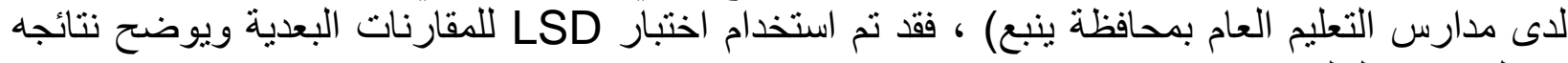

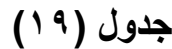
جدول (9 1 ) التالي:

نتائج اختبار LSD للمقارنات البعدية لمعرفة اتجاه الفروق بين متوسطات استجابات معلمي مدارس التعليم العام بمحافظة

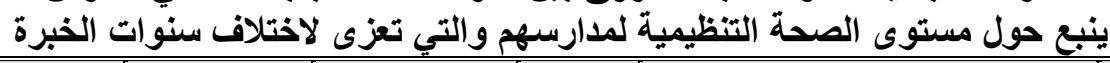

\begin{tabular}{|c|c|c|c|c|c|c|}
\hline فأكثر سنة & إلى أقل من من 1 من & سنو من · 1 أقل & الحستبي & 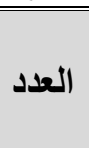 & سنوات الخبرة & المتغير \\
\hline & & 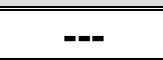 & $r . r$ & $1 \cdot r$ & أقل من · ا سنوات & \multirow{3}{*}{ القيادة بالزمالة: } \\
\hline & --- & & r.Y & 104 & من · إلى أقل من · T سنة & \\
\hline \multirow[t]{3}{*}{---} & & $* . . r \varepsilon$ & r.rv & 0. & r r سنة فأكثر & \\
\hline & & $\begin{array}{ll}-- \\
-\end{array}$ & $\overline{T .1 T}$ & $1 \cdot r$ & أقل من · ا سنوات & \multirow{3}{*}{ التماء المابع : } \\
\hline & --- & & $r . r 4$ & 104 & من · ا إلى أقل من · r سنة & \\
\hline \multirow[t]{3}{*}{$-\cdots$} & & $* * . . \leqslant 7$ & $r .09$ & 0. & r r سنة فأكثر & \\
\hline & & $\begin{array}{ll}-- \\
\end{array}$ & r.90 & $1 \cdot r$ & أقل من · أسنوات & \multirow{3}{*}{ المجموع الكلي } \\
\hline & --- & & r.IT & 104 & من · ا إلى أقل من · Y سنة & \\
\hline $\begin{array}{ll}-- \\
\end{array}$ & & $* . . \mu$ & r. ro & 0 . & · r سنة فأكثر & \\
\hline
\end{tabular}

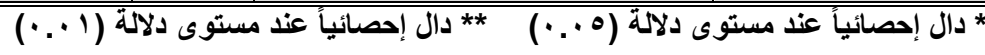
يتبين من جدول (9 ( ) السابق ما يلي: 
- توجد فروق ذات دلالة إحصائية عند مستوى الدلالة (0. . • ) بين متوسطات استجابات معلمي

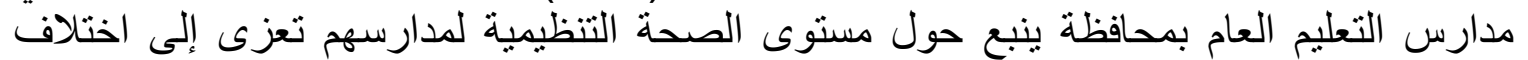
سنوات الخبرة. المعلمين اللذين سنوات خبرتهم (· · سنة فأكثر) مقابل استجابات المعلمين اللذين

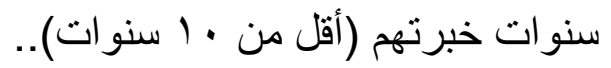
توجد فروق ذات دلالة إحصائية عند مستوى الدلالة (0. (. • ) بين متوسطات استجابات معلمي

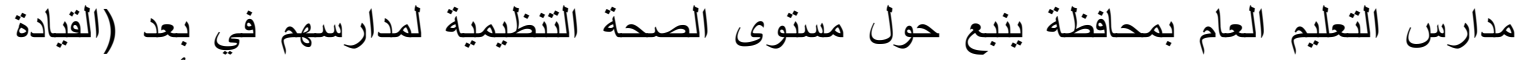

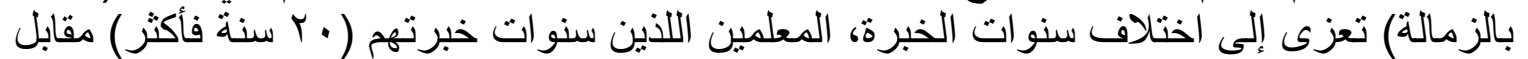

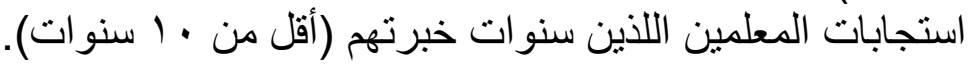

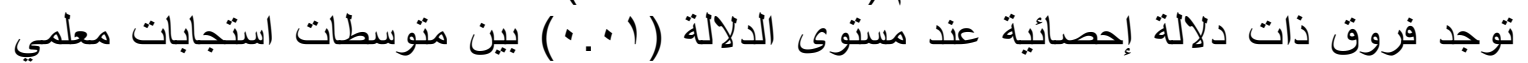

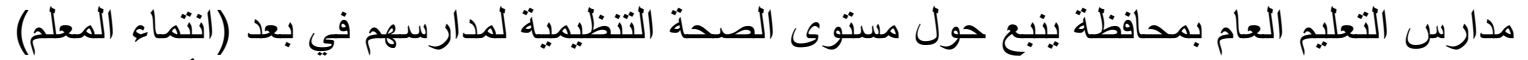

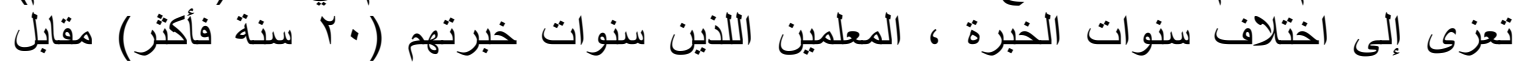

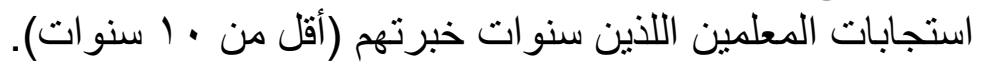

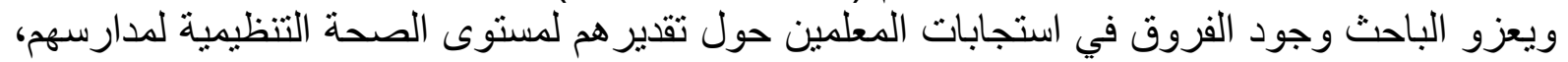

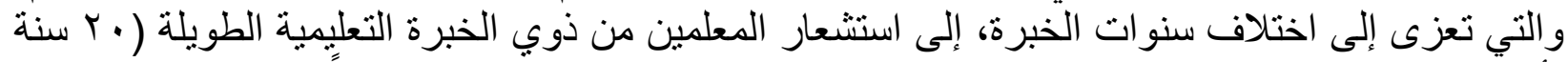

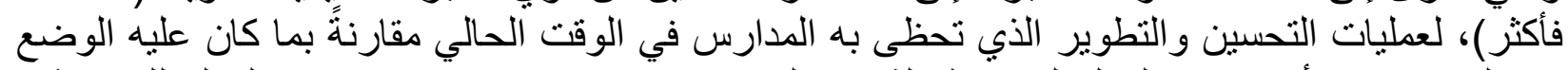

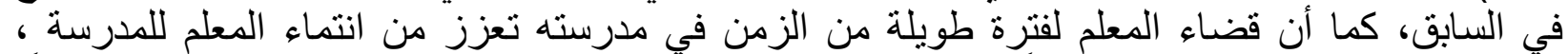

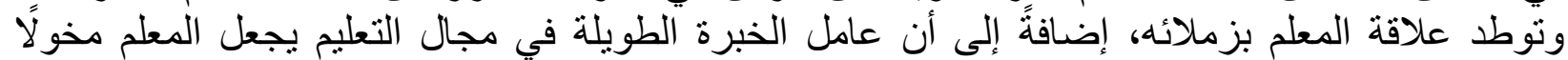

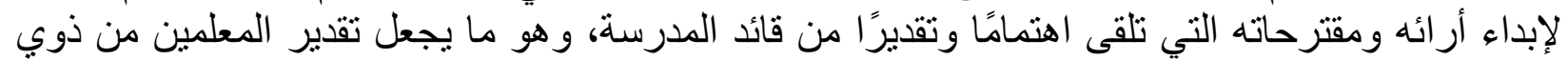

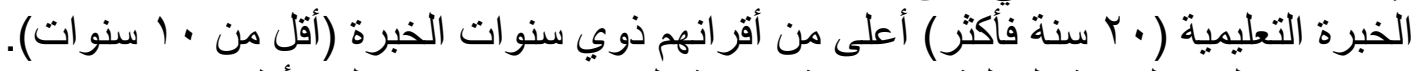

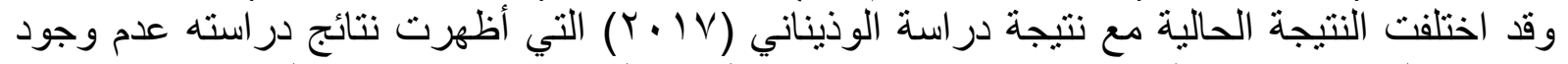
فروق تعزى لمتغير سنوات الخبرة. ويعزى الاختلاف في النتائج إلى الاختلاف في بيئة الدر اسة ومجتمعة دانها.

\section{توصيات الاراسة: \\ استناداً إلى النتائج التي كثفت الهُه عنها الدراسة فإن الباحث يوصى بما يلي:}

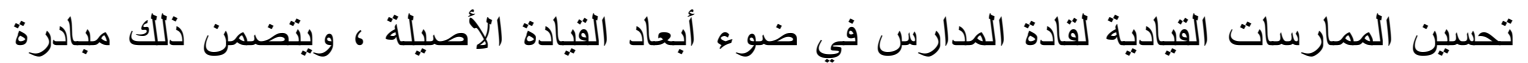

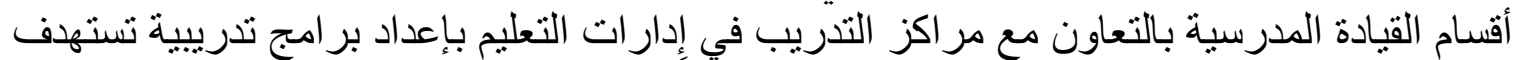

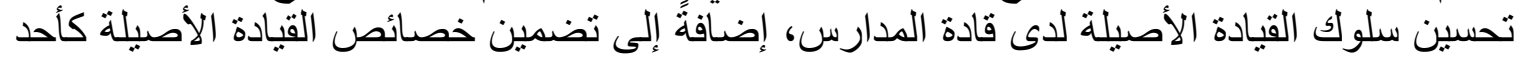

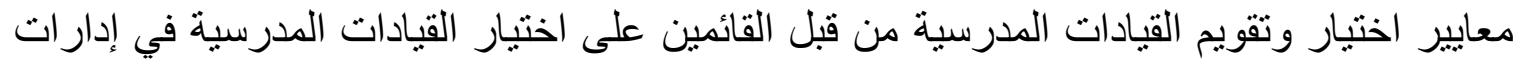
التعليم .

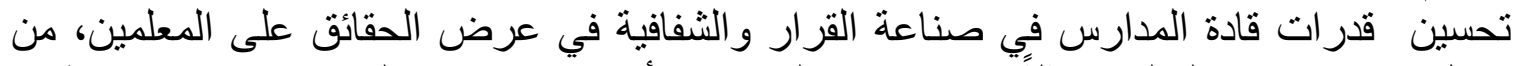

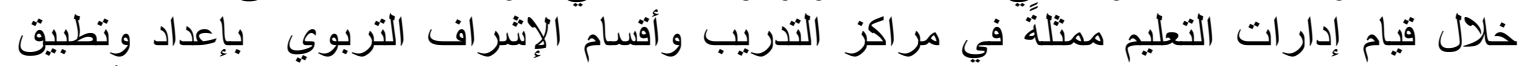
البرامج التدريبية فيما يتعلق بمهار ات : الاتصال التهات الفعال، والتحليل الموضو عي للبيانات ، و وأساليب

اتخاذ القر ار الرشيد.

قياس رضا المعلمين عن أداء قيادة المدرسة، وإتاحة الفرصة لهح بتقديم مقترحاتهم حول التطوير،

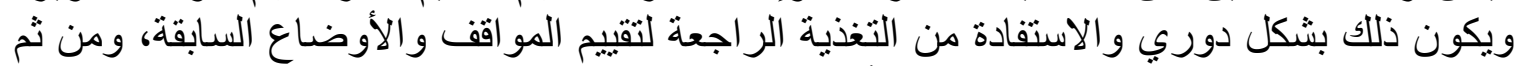

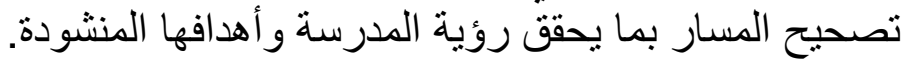
تحسين مستوى الصحة التنظيمية والتأكد من تو افر أبعادها في مدارس التعليم العام، وذلك بقدية بقاس

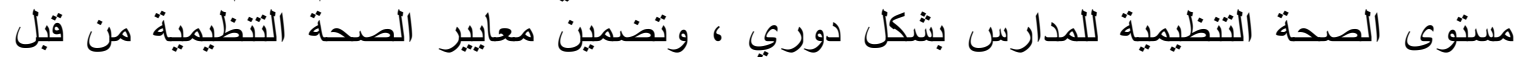

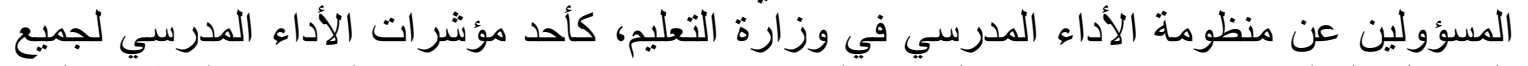

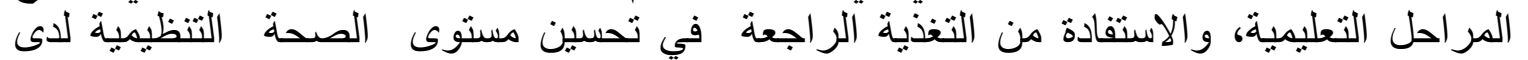
المدارس.

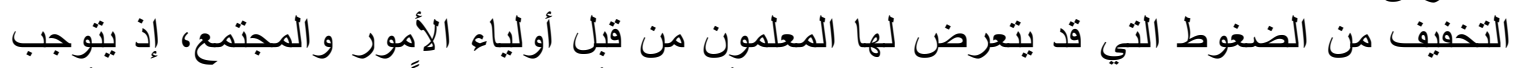
على وزارة التعليم وضع آلية لتحديد دور مجلس أولياء الأمور، إضافةً إلى تقنين زيار ات أولئ أولياء 
أمور الطلاب والمشرفين التربويين للمدارس بما يحقق التوازن والتكامل المؤسسي للددرسة، وتنظيم أساليب التواصل والمنرفين المدرسة والأسرة.

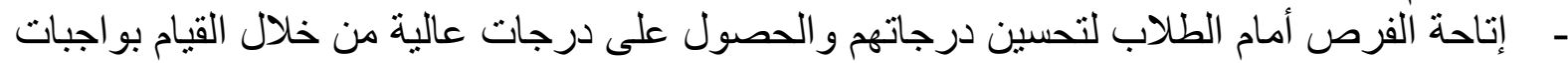

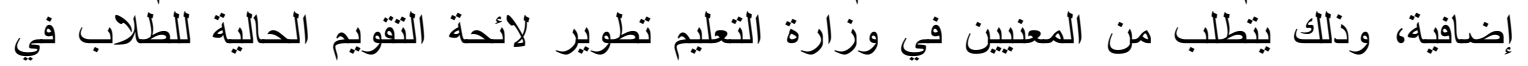

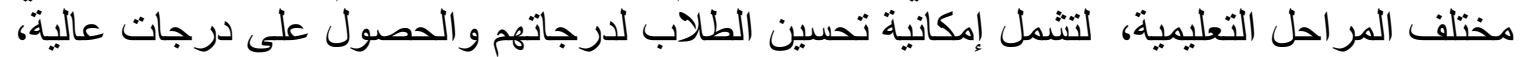
من خلال القيام بواجبات إضافية.

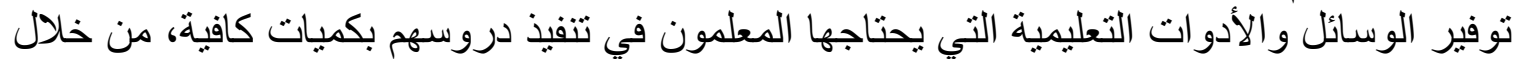

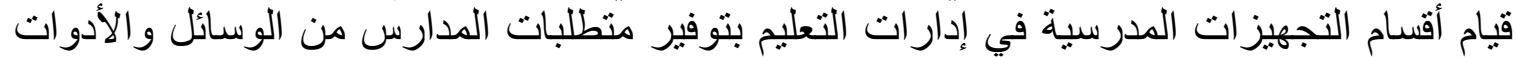

التعليمية المتوفرة لايها.

- رفع مستوى الكفاءة والفاعلية لدى قادة المدارس في استثمار الموارد المادية للمدرسة، وتوجيهها

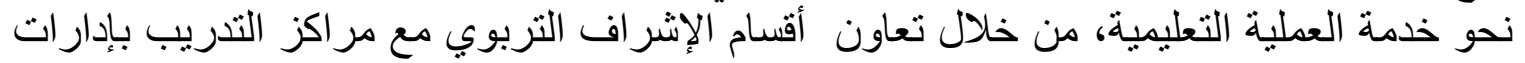

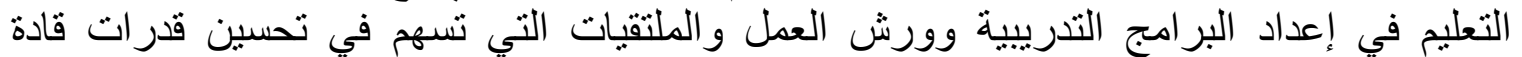
المدارس في إدارة الموارد المادية بما يحقق الأهداف التعليمية.

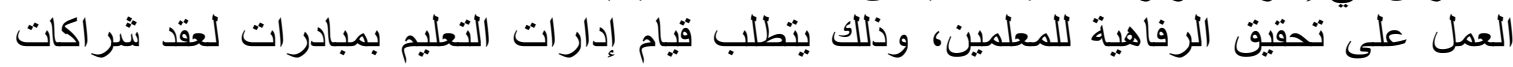

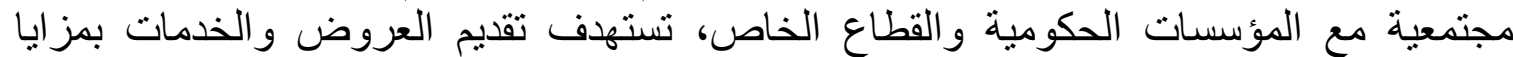

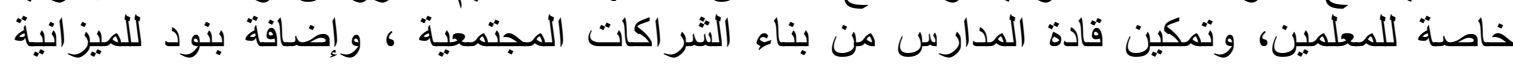

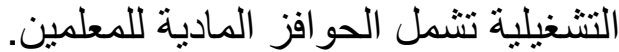

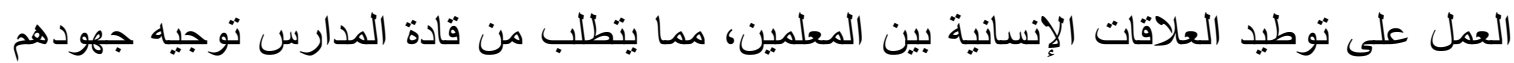

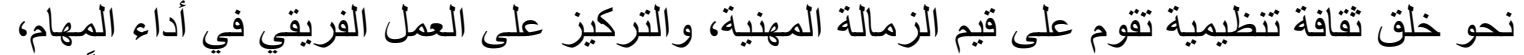

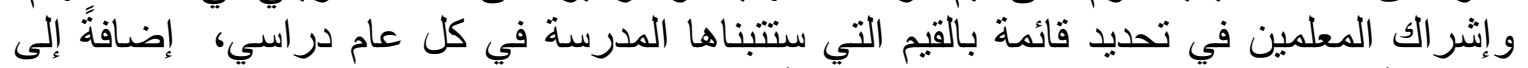
تنظيم الأنشطة واللقاءوات التي تهدف إلى تعزيز أواصر المحبة والفئ والصداقة بين المعلمين.

\section{البحوث والدراسات المقترحة:}

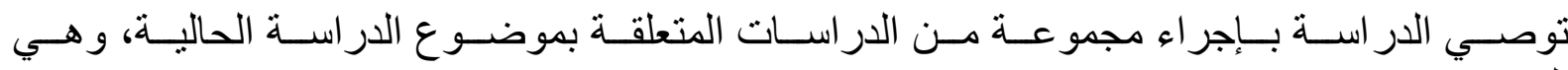
كالتالي: - 20 - n

- إجراء دراسة مماتلة للار اسة الحالية مع إضافة متغيرات ديموغر افية أخرى، كالجنس، و المسمى الوظيفي، ونوع التعليم(أهلي-حكومي).

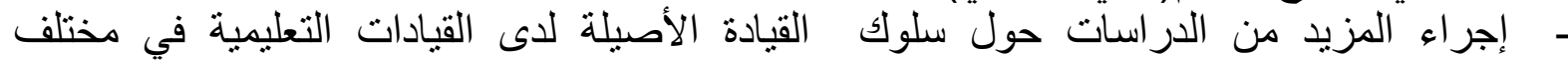

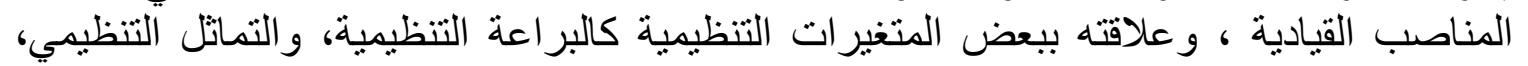
و المواطنة التنظيمية. - إجراء دراسة للكثف عن العلاقة بين الصحة التنظيمية وأنماط أخرى من القيادة غير القيادة - إجراء دراسة حول متطلبات تطبيق الصحة التنظيمية في مدارس التعليم العام من وجهة نظر المعلمين و المشرفين التربويين وقادة المدارس. 


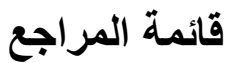

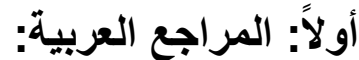

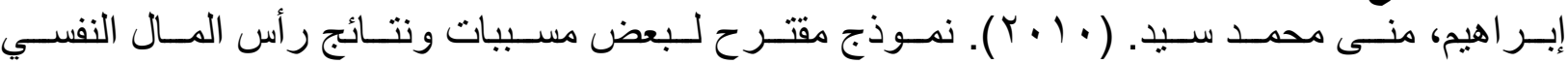

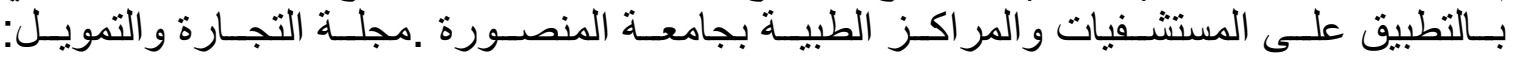

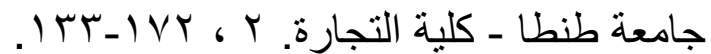

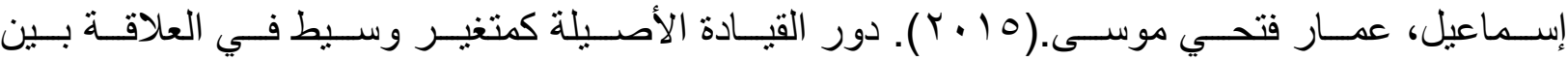

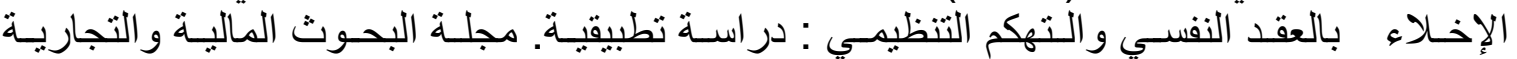

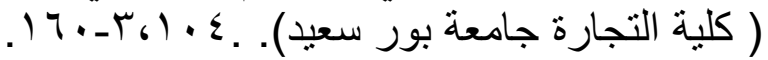

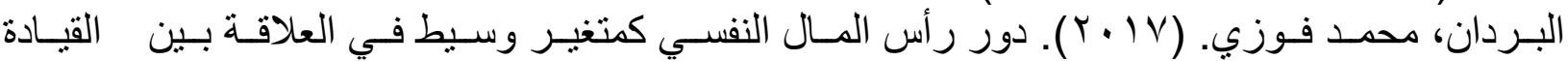

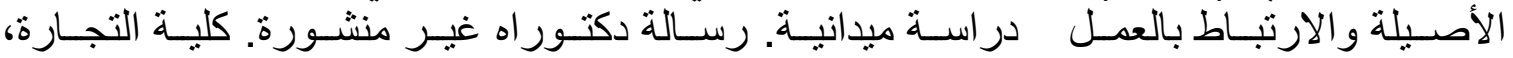

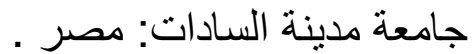

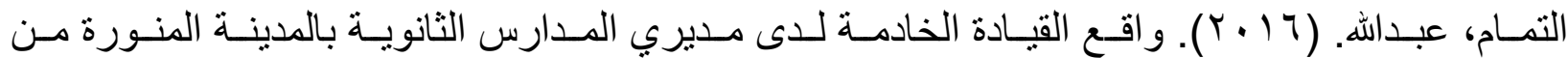

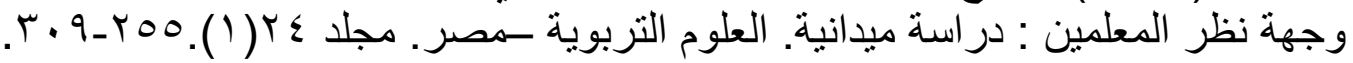

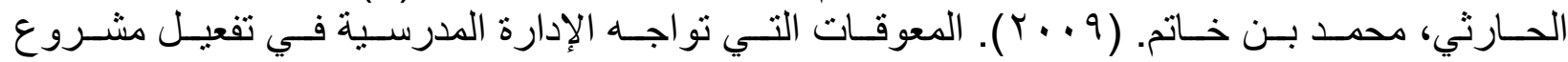

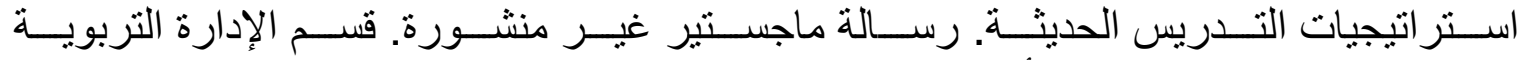

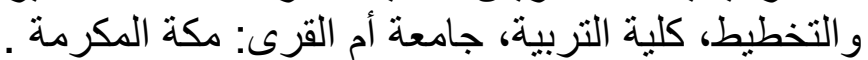

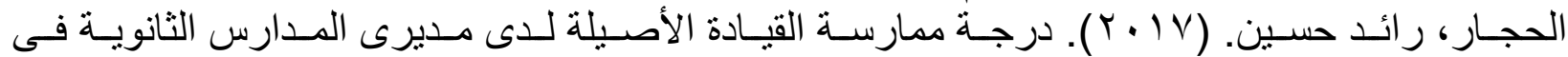

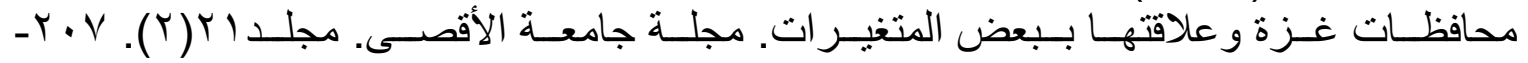

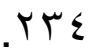

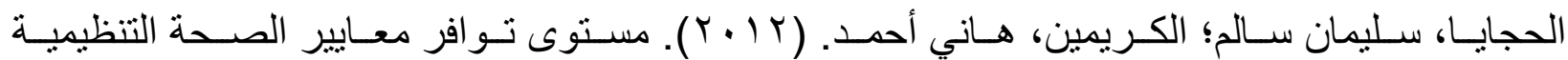

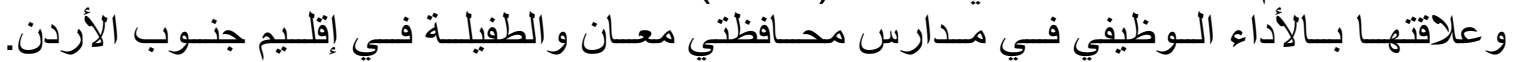

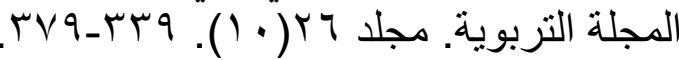

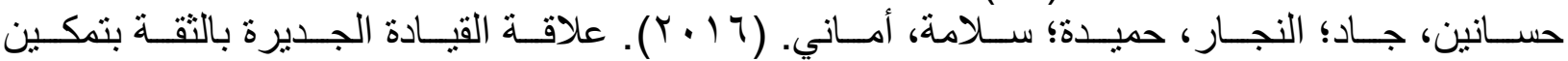

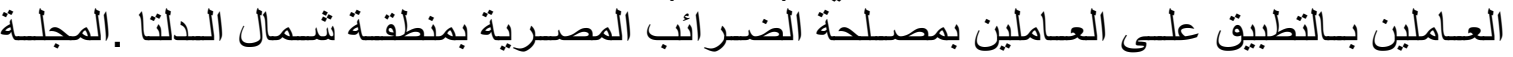

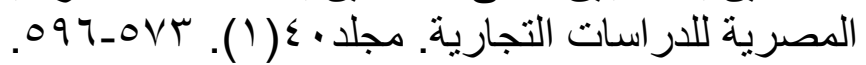

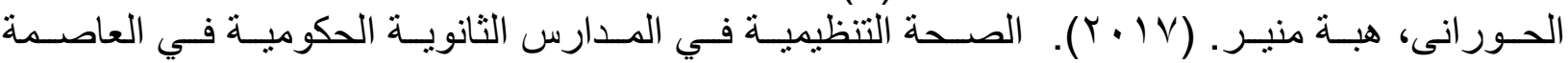

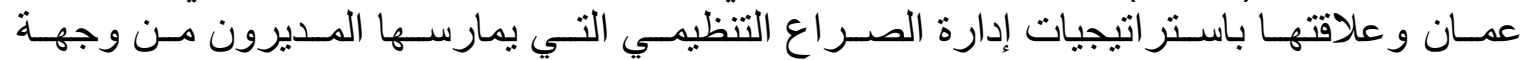

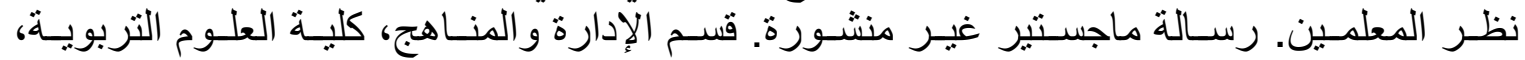
جامعة الشرق الأوسط: عمان.

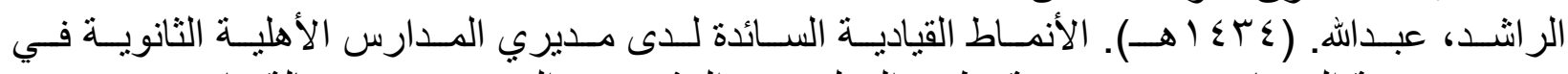

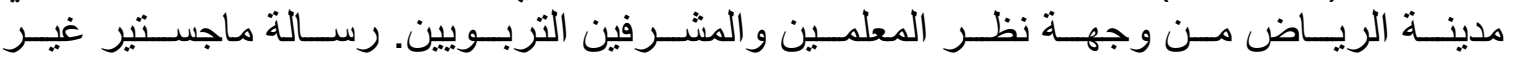

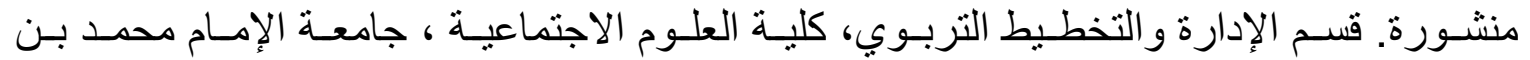
سعود : الرياض.

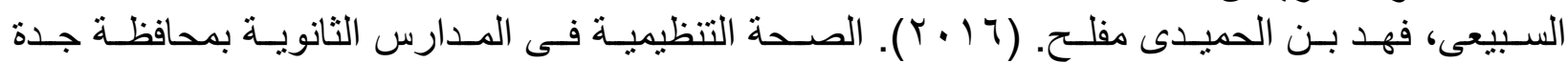

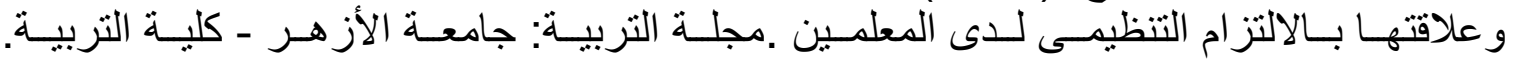

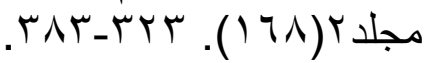

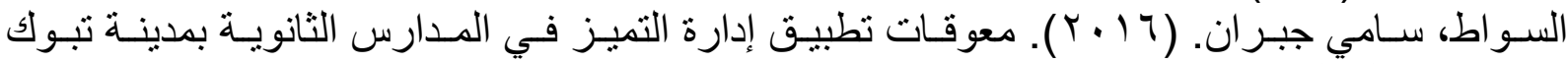

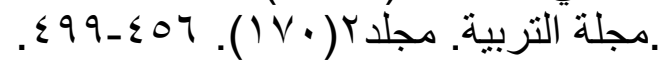

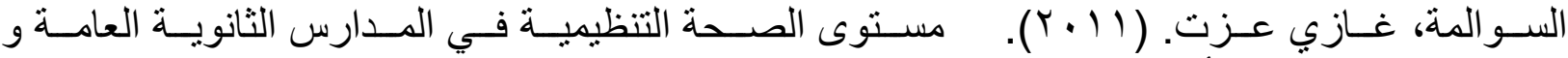

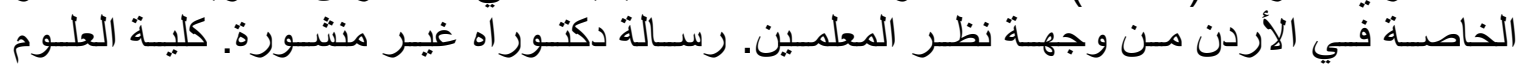

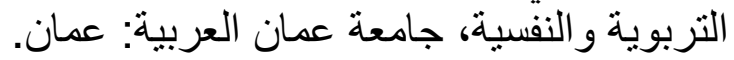

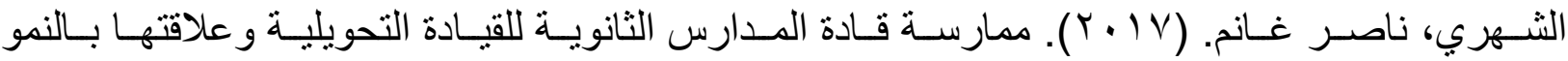

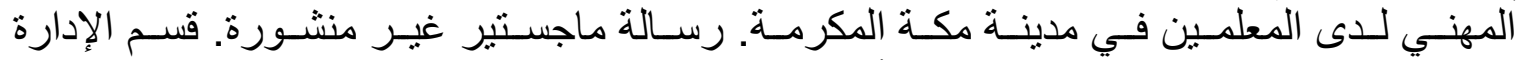

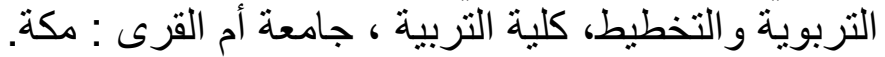




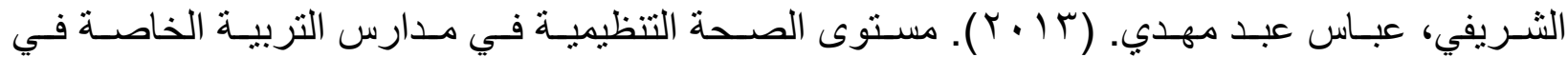

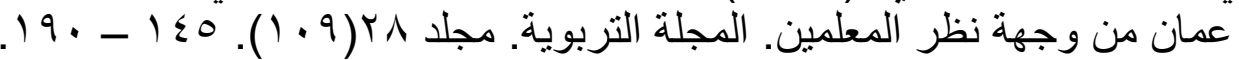

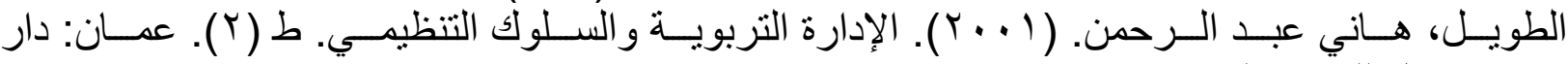

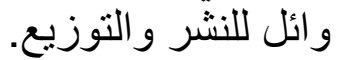

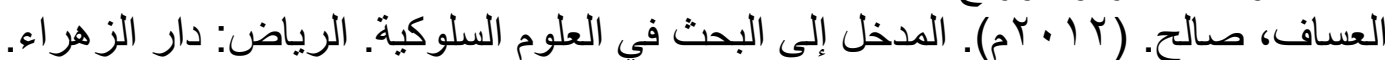

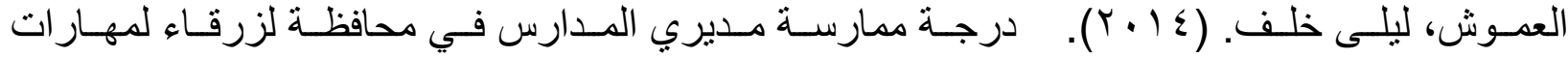

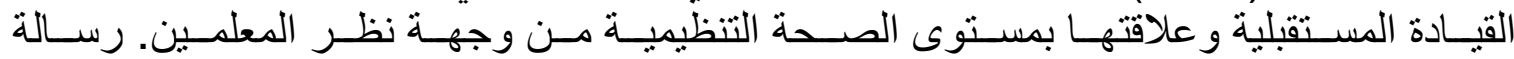
ماجستير غير منشورة. الجامعة الهاشمية: الأردن.

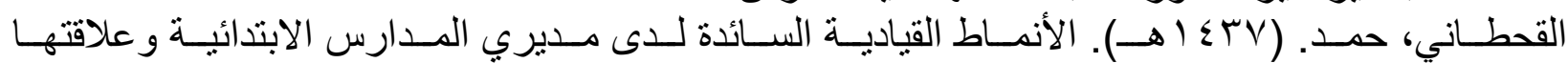

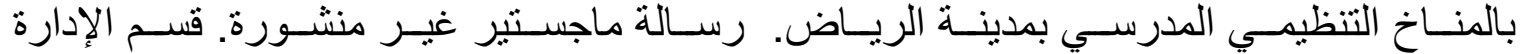

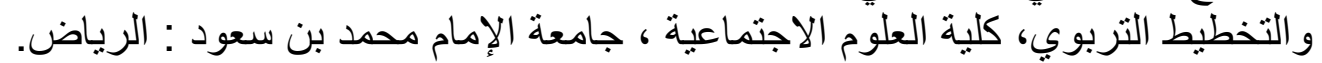

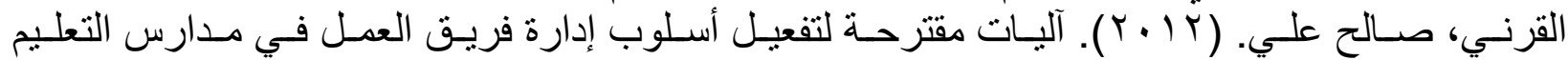

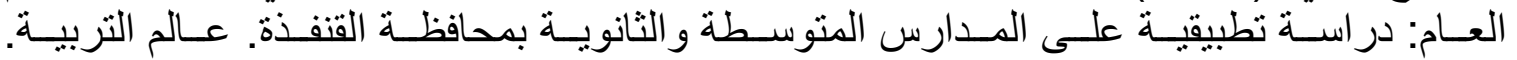

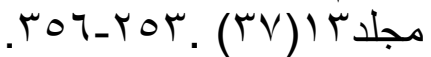

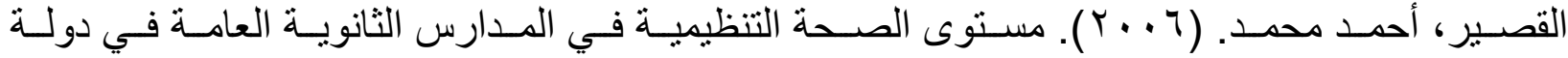

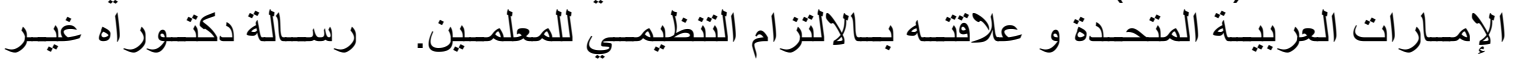
منشورة. كلية الدراسات التربوية العليا، جامعة عمان العربية: عمان.

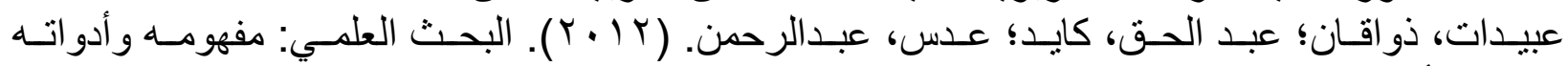

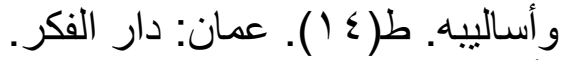

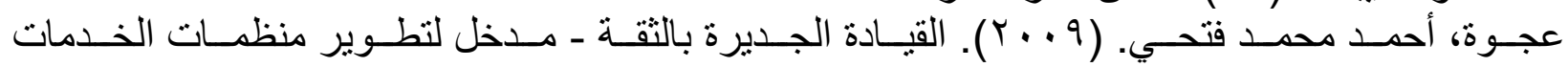

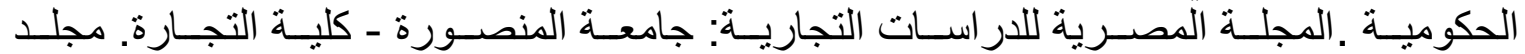
$.01-V 9 .(Y)$ r

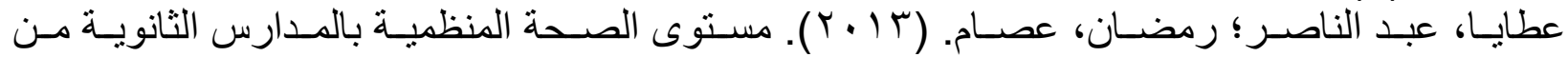

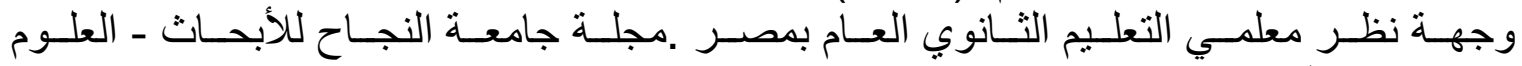

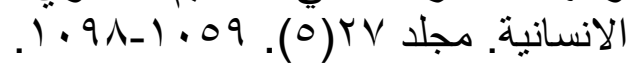

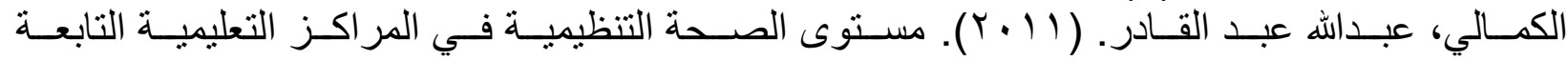

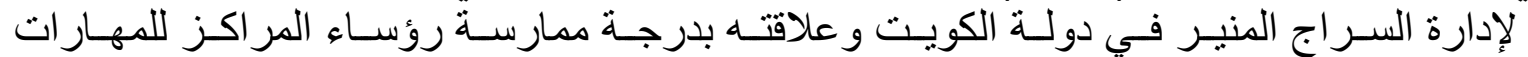

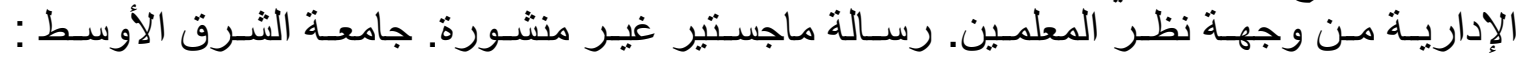
عمان.

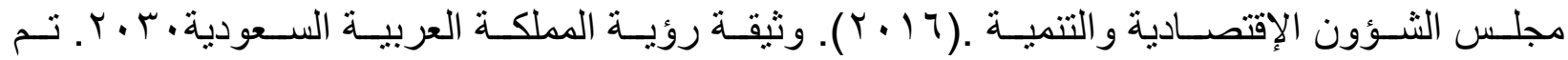

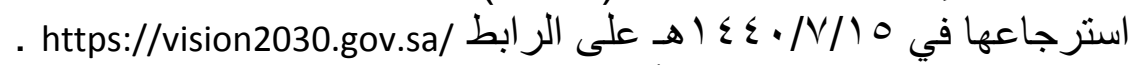

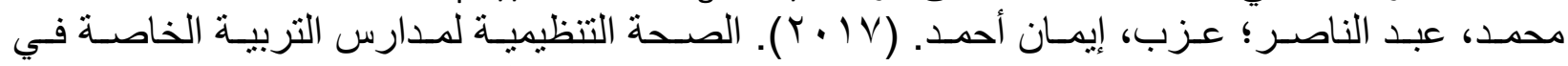

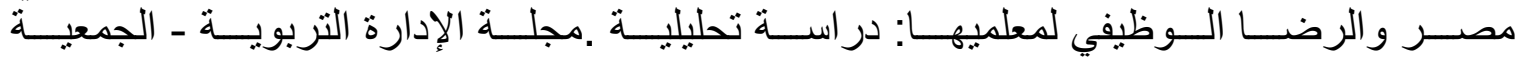

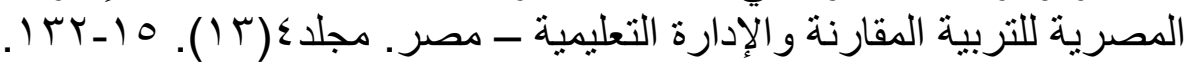

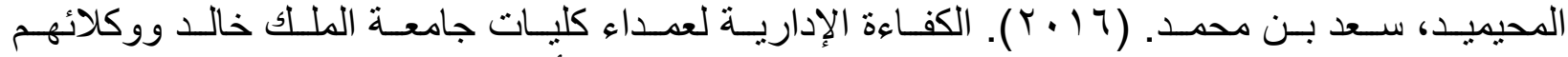

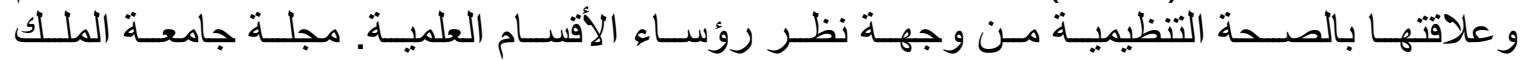

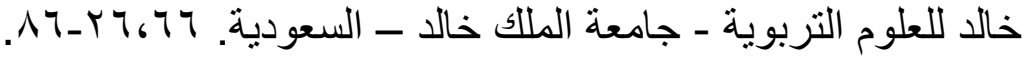

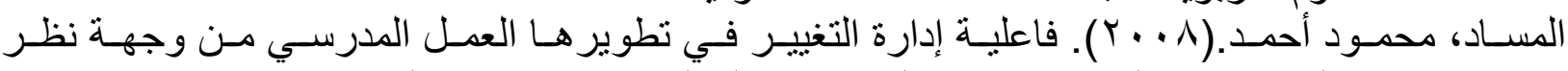

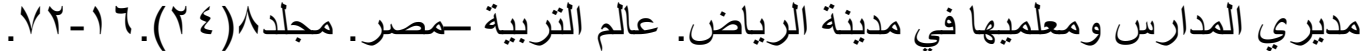

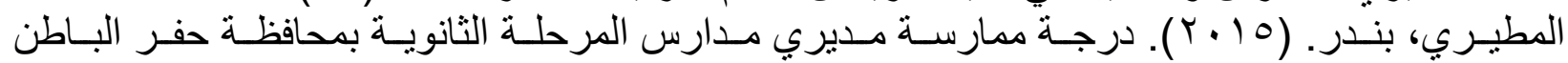

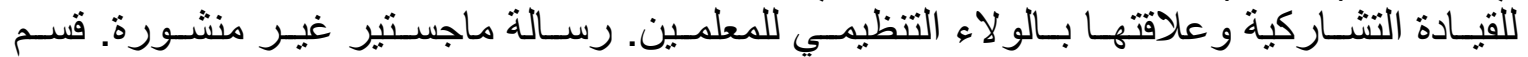
الإدارة التربوية والتخطيط، كلية التربية ، جامعة أم القرى التط : مكة. 


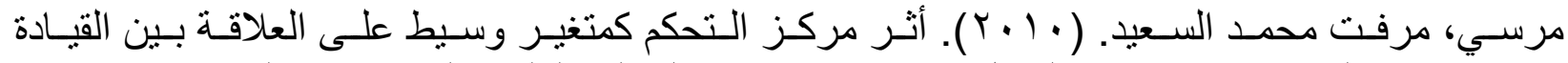

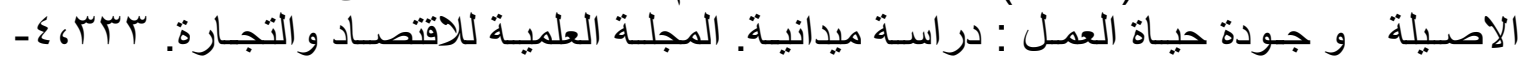

.

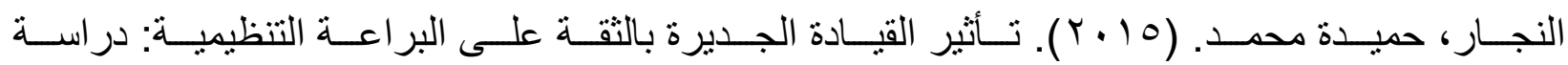

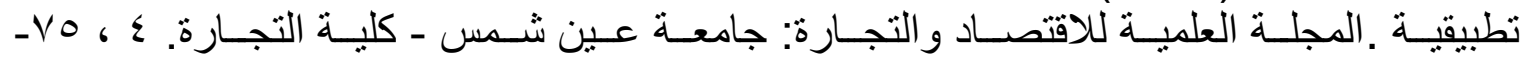
.111

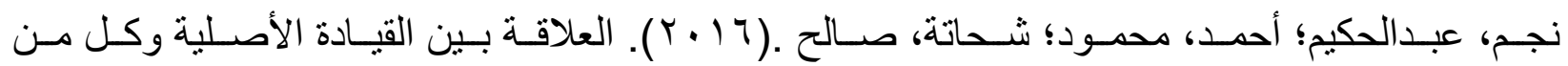

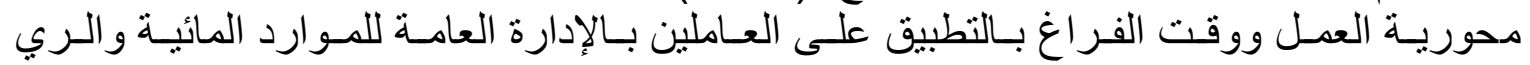

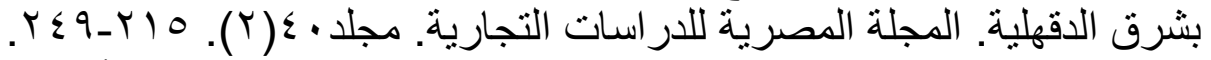

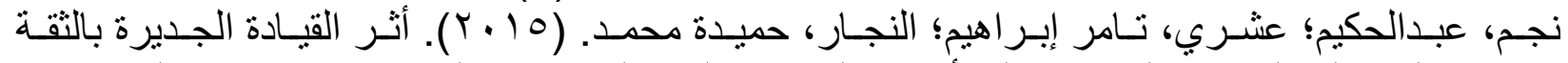

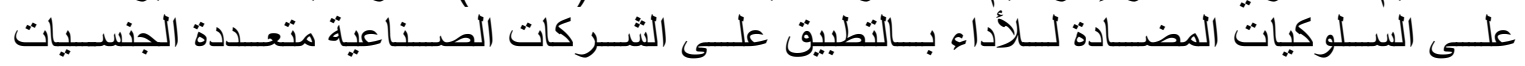

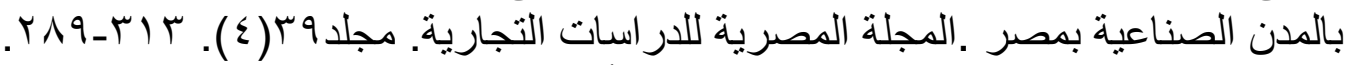

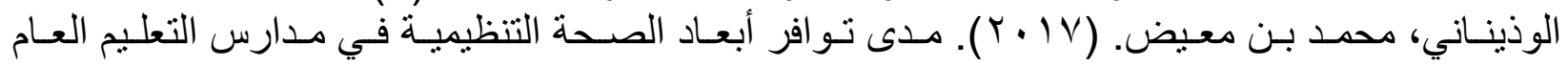

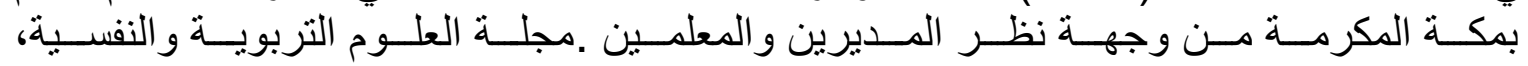

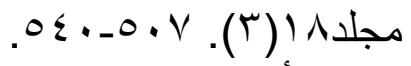

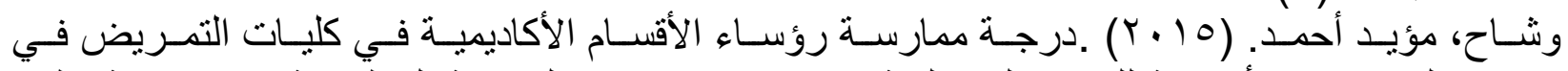

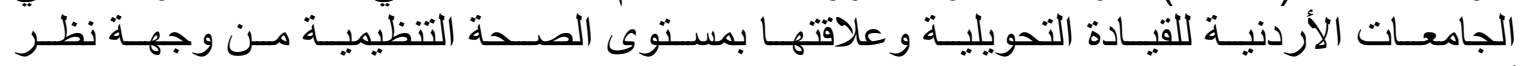

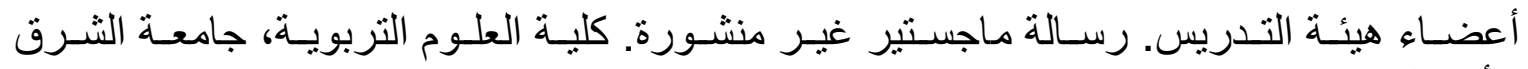
الأوسط: عمان. ثانيا: المراجع الأجنبية:

Avolio, B. J., \& Gardner, W. L. (2005). Authentic leadership development: Getting to the root of positive forms of leadership. The leadership quarterly, 16 (3), 315-338.

Avolio, B. J., Gardner, W. L., Walumbwa, F. O., Luthans, F., \& May, D. R. (2004). Unlocking the mask: A look at the process by which authentic leaders impact follower attitudes and behaviors. The leadership quarterly, 15 (6), 801-823.

Avolio, B. J., Walumbwa, F. O., \& Weber, T. J. (2009). Leadership: Current theories, research, and future directions. Annual review of psychology, 60, 421-449.

Feng Feng,I.(2016). School Principals' Authentic Leadership and Teachers' Psychological Capital: Teachers' Perspectives. International Education Studies, 9 (10),9020-9039.

George, B., Sims, P., McLean, A. N., \& Mayer, D. (2007). Discovering your authentic leadership. Harvard business review, 85 (2), 129.

George, B. (2003). Authentic leadership: Rediscovering the secrets to creating lasting value. John Wiley \& Sons.

Karadag, E., \& Oztekin-Bayir, O. (2018). The Effect of Authentic Leadership on School Culture: A Structural Equation Model. International Journal of Educational Leadership and Management, 6 (1), 40-75.

Kernis, M. H. (2003). Toward a conceptualization of optimal selfesteem. Psychological inquiry, 14 (1), 1-26. 
Kets de Vries, Manfred F.R. (2006). The Leader on the Couch A Clinical Approachto Changing People and Organizations. Cornwall UK: JosseyBass.

Luthans, F. (2002). The need for and meaning of positive organizational behavior. Journal of Organizational Behavior: The International Journal of Industrial, Occupational and Organizational Psychology and Behavior, 23 (6), 695-706.

Luthans, F., \& Avolio, B. J. (2003). Authentic leadership development. Positive organizational scholarship, 241, 258.

Mazutis, D., \& Slawinski, N. (2007). The art of conversation: How authentic leaders influence organizational learning. Learning Fusion, 662-675.

Miles, M. B. (1969). Planned change and organizational health: Figure and ground. Organizations and human behavior, 375-391.

Parlar, H., \& Cansoy, R. (2017). Examining the Relationship between Instructional Leadership and Organizational Health. Journal of Education and Training Studies, 5 (4), 18-28.

Pless, N. M., \& Maak, T. (2011). Responsible Leadership: Pathways to the Future. J Bus Ethics, 98, 3-13.

Sagnak, Mesut.\& Kuruoz, Mehmet.(2017). Authentic Leadership and Altruism: The Mediating Role of Meaningfulness. Universal Journal of Educational Research, 5 (3), 447-452.

Sinclair, M. (2010). Authentic leadership behaviors of secondary school principals and job satisfaction of the multigenerational teacher workforce (Doctoral dissertation). Retrieved from ProQuest Dissertations and Theses database. (UMINo. 3447761)

Walumbwa, F. O., Avolio, B. J., Gardner, W. L., Wernsing, T. S., \& Peterson, S. J. (2008). Authentic leadership: Development and validation of a theory-based measure. Journal of management, 34 (1), 89-126. 